\title{
Application of Fluorine- and Nitrogen-Walk Approaches: Defining the Structural and Functional Diversity of 2- Phenylindole Class of CB1 Receptor Positive Allosteric Modulators
}

\author{
Sumanta Garai ${ }^{\dagger} \neq$, Pushkar M. Kulkarni ${ }^{\dagger} \neq$, Peter C. Schaffer ${ }^{\dagger}$, Luciana M. Leo ${ }^{€}$, Asher L. \\ Brandt $^{\Phi}$, Ayat Zagzoog ${ }^{\Phi}$, Tallan Black ${ }^{\Phi}$, Xiaoyan Lin ${ }^{£}$, Dow P. Hurst ${ }^{\ddagger}$, David R. Janero $\S$, \\ Mary E. Abood ${ }^{£}$, Anaelle Zimmowitch ${ }^{£}$, Alex Straiker ${ }^{£}$, Roger G. Pertwee ${ }^{\#}$, Melanie Kelly^, \\ Anna-Maria Szczesniak ${ }^{\wedge}$, Eileen M. Denovan-Wright ${ }^{\wedge}$, Ken Mackie ${ }^{£}$, Andrea G. Hohmann ${ }^{£}$, \\ Patricia H. Reggio ${ }^{\ddagger}$, Robert B. Laprairie ${ }^{*}, \Phi,{ }^{\wedge}$, Ganesh A. Thakur ${ }^{\star}, \dagger$ \\ tDepartment of Pharmaceutical Sciences, School of Pharmacy, Bouvé College of Health \\ Sciences, Northeastern University, Boston, Massachusetts 02115, United States. Present \\ address: Department of Pharmaceutical Sciences, 145, 140, The Fenway, Northeastern \\ University, Boston, MA, USA - 02115. \\ ${ }^{\Phi}$ College of Pharmacy and Nutrition, University of Saskatchewan, 104 Clinic PI, Saskatoon, SK, \\ Canada - S7N2Z4. Present address: College of Pharmacy and Nutrition, University of \\ Saskatchewan, 104 Clinic PI, Saskatoon, SK, Canada - S7N2Z4. \\ ${ }^{€}$ Center for Substance Abuse Research, Lewis Katz School of Medicine, Temple University, \\ Philadelphia, PA 19140, United States \\ ${ }^{¥}$ Center for Drug Discovery, University of North Carolina Greensboro, Greensboro, North Carolina \\ 27402, United States \\ §Department of Pharmaceutical Sciences, Bouvé College of Health Sciences, Department of \\ Chemistry and Chemical Biology, College of Science, and Health Sciences Entrepreneurs; \\ Northeastern University, Boston, Massachusetts 02115, United States. \\ EProgram in Neuroscience, Indiana University, Bloomington, Indiana; Psychological and Brain \\ Sciences, Indiana University, Bloomington, Indiana; Gill Center for Biomolecular Science, \\ Bloomington, IN 47405, United States. \\ ^Department of Pharmacology, Faculty of Medicine, Dalhousie University, 5850 College St, \\ Halifax, NS, Canada - B3H4R2 \\ \#School of Medicine, Medical Sciences and Nutrition, Institute of Medical Sciences, University of \\ Aberdeen, Aberdeen AB25 2ZD, Scotland, U.K.
}

\footnotetext{
“Corresponding Authors: Ganesh A Thakur: g.thakur@northeastern.edu, Robert Laprairie: Robert.laprairie@usask.ca.

\$Authors contributed equally to this work.

Supporting Information.

The Supporting Information is available free of charge on the ACS Publications website at DOI:. Preliminary c-AMP and b-arrestin2 data graph of all GAT211 analogs.

The authors declare no competing financial interest.
} 


\section{Abstract}

Cannabinoid 1 receptor (CB1R) allosteric ligands hold far-reaching therapeutic promise. We report application of fluoro- and nitrogen-walk approaches to enhance the drug-like properties of GAT211, a prototype CB1R allosteric agonist-positive allosteric modulator (ago-PAM). Several analogs exhibited improved functional potency (cAMP, $\beta$ arrestin2), metabolic stability, and aqueous solubility. Two key analogs, GAT591 (6r) and GAT593 (6s), exhibited augmented allosteric-agonist and PAM activities in neuronal cultures, improved metabolic stability, and enhanced orthosteric agonist binding (CP55,940). Both also exhibited good analgesic potency in the CFA inflammatory-pain model with longer duration of action over GAT211 while devoid of adverse cannabimimetic effects. Another analog, GAT592 (9j), exhibited moderate ago-PAM potency and improved aqueous solubility with therapeutic reduction of intraocular pressure in murine glaucoma models. The SAR findings and the enhanced allosteric activity in this class of allosteric modulators were accounted for in our recently developed computational model for CB1R allosteric activation and positive allosteric modulation.

\section{Graphical Abstract}

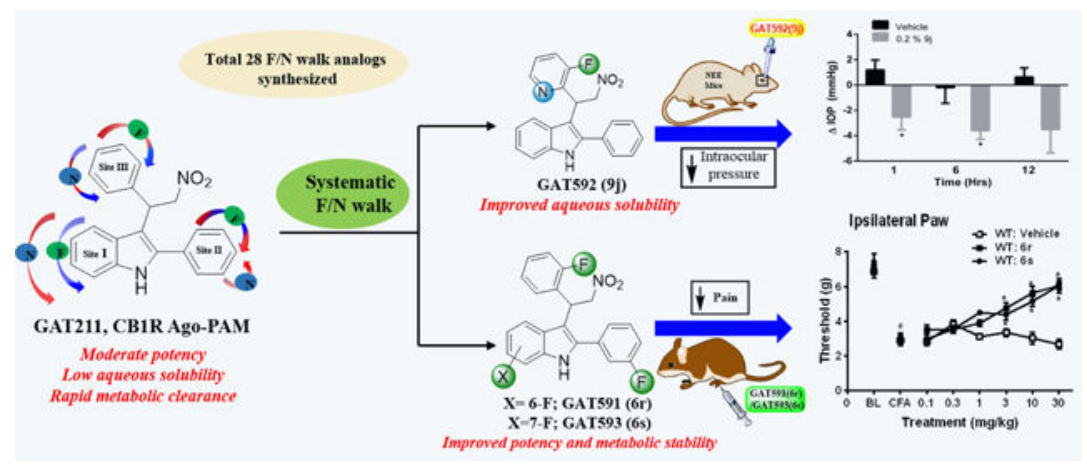

\section{Keywords}

Allosteric modulator; CB1 Cannabinoid receptors; G-protein coupled receptor; Positive allosteric modulator (PAM); cAMP; GTP $\gamma \mathrm{S}$; Fluorine walk; Nitrogen walk; Structure-activity relationship; CFA model of pain; NEE model of glaucoma; MMC studies

\section{INTRODUCTION:}

The endocannabinoid system (ECS) is an ubiquitous information transducing network comprised of endocannabinoid lipid-signaling molecules [mainly, 2-arachidonoylglycerol (2-AG) and anandamide (AEA)], type 1 and 2 cannabinoid G protein-coupled receptors (GPCRs) (CB1R and CB2R), and endocannabinoid-synthesizing and -inactivating enzymes. ${ }^{1}$ Widely distributed throughout the human body, the ECS helps control and modulate multiple physiological processes such that aberrant ECS activity has been implicated in a broad range of disease states. ${ }^{1}$ The prominence of CB1R for regulating synaptic activity in the central nervous system and its varied roles in the periphery ranging from metabolic control to modulation of smooth muscle tone have focused significant attention on the role of abnormal CB1R-mediated signal transduction in disease etiology and the potential of 
pharmacological CB1R modulation as treatment modality. Indeed, this GPCR, is recognized as a promising therapeutic target for several conditions including pain, neuropathy, cachexia, glaucoma, and post-traumatic stress disorder. ${ }^{2-11}$

The CB1R partial agonist and psychoactive plant (phyto)cannabinoid, $\Delta^{9}$ tetrahydrocannabinol (THC), is approved in Canada and the European Union for treating cachexia and as a third-line pain treatment. ${ }^{12,13}$ As an orthosteric agonist, THC binds to the same site in CB1R as the endogenous cannabinoids, thereby directly activating the receptor. Its demonstrated medical utility notwithstanding, pharmacological CB1R activation by targeted orthosteric agonists carries undesirable side-effect risks including intoxication, delirium, abuse liability, and development of tolerance and dependence, which have significantly limited their therapeutic utility.

As a promising alternative to orthosteric agents for therapeutic GPCR targeting, allosteric modulators have been pursued. These ligands bind to an allosteric site on the target GPCR that is subtype-specific and topographically distinct from the orthosteric ligand-binding pocket. The cooperative interaction between bound orthosteric and allosteric ligands offers the potential to tune the efficacy/affinity of the orthosteric ligand in a site- and event-specific manner. Binding of the allosteric modulator is believed to induce structural changes in the GPCR that affects the receptor's affinity for and/or the efficacy of an orthosteric ligand to generate receptor conformational states with unique structural and functional properties that may be therapeutically exploitable. ${ }^{14-21}$ In particular, allosteric CB1R modulation by smallmolecule ligands has several appealing features that could translate into improved safety, more flexible therapeutic dose-ranging, and avoidance of the inherent side-effect risks of orthosteric CB1R ligands. CB1R allosteric modulators that potentiate [positive allosteric modulators (PAMs)] or inhibit [negative allosteric modulators (NAMs)] orthosteric signaling have recently been described (Fig. 1). CB1R (ago)-PAMs have garnered attention as potential treatments for pain and neurodegenerative diseases without the risk of psychobehavioral and other side effects carried by direct orthosteric CB1R activators. ${ }^{22-24}$

We recently described the pharmacological characterization of GAT211, a CB1R allosteric agonist and PAM (i.e. ago-PAM) and the enantiospecific interaction of its enantiomers (GAT228 and GAT229) with CB1R. It is noteworthy to mention that this is the first small molecule CB1R modulator from the 2-phenylindole structural class that was correctly characterized as a CB1R ago-PAM. With human-recombinant CB1R (hCB1R) and native receptor, GAT211 (racemic) enhanced both $\left[{ }^{3} \mathrm{H}\right] \mathrm{CP} 55,940$ binding and agonist-mediated CB1R signaling, whereas GAT228 ( $R$-enantiomer) was an allosteric CB1R partial agonist and GAT229 ( $S$-enantiomer) was a potent CB1R PAM. ${ }^{25}$ Although GAT211 was first reported as a CB1R PAM by Astra Zeneca through an HTS campaign, it was only partially characterized in vitro and was not studied further. Another CB1R PAM ZCZ-011 was also first characterized as PAM $^{22}$, and later it was shown to behave as ago-PAM. ${ }^{23,26}$ GAT211 was instrumental in establishing the role of CB1R PAMs in treating chronic and neuropathic pain, glaucoma, Huntington's disease, and other CNS disorders. In vivo, GAT211 showed preclinical therapeutic efficacy against neuropathic pain ${ }^{27}$ and did not produce cardinal signs of CB1R activation associated with orthosteric cannabinoid receptor agonists. In murine disease models, GAT211 and GAT229 attenuated IOP, a major risk factor for glaucoma, a 
progressive neurodegenerative disease in which damage to the optic nerve results in loss of retinal ganglion cells, and irreversible vision loss and blindness ${ }^{26,28}$. GAT211 and GAT229 also reduced the signs and symptoms of Huntington's disease, while delaying its progression. ${ }^{29}$ GAT211, however, has moderate PAM potency, low aqueous solubility and rapid metabolic clearance. These findings have fostered an interest in understanding design parameters for productive structure-activity relationships (SAR) around GAT211 and exploring the potential for additional, novel candidates with comparable, or improved, druglike properties while retaining or enhancing CB1R PAM activity. In general, SAR studies of GPCR allosteric modulators have been reported to be challenging, yielding a flat-SAR. ${ }^{30}$ The fluorine- and nitrogen-walk approaches, which respectively involve the replacement of a hydrogen atom with fluorine or a $\mathrm{CH}$-function with nitrogen have been reported as successful approaches to optimize biological activity, metabolic stability, and overall physicochemical properties. ${ }^{31-34}$

Here, we report the application of fluorine- and nitrogen-walk approaches to the GAT211 scaffold to develop potent and efficacious CB1R allosteric modulators with improved physicochemical properties. We detail the development of the resulting novel analogs and their in vitro characterization through functional assays (cAMP, $\beta$-arrestin2, GTP $\gamma$ S), including electrophysiological and radioligand binding experiments. The three key compounds resulting from these studies exhibited therapeutic efficacy in preclinical animal models of glaucoma (ocular hypertensive model and NEE mice model) and pain (CFA model).

\section{Ligand Design:}

We exploited observations that systematic introduction or "walk" of fluorine around the core structure of an allosteric ligand may retain, or enhance, chemical properties, pharmacological activity, metabolic stability, and/or bioavailability. ${ }^{35,36}$ As a scaffoldhopping approach in a leadoptimization drive, the "fluorine walk" (F-walk) has met success for identifying regions of the allosteric ligand (in)tolerant to functionalization or contributory to a "flat" or "steep" SAR as routinely observed for allosteric modulators and illuminating the electronic properties of the ligand-binding site. ${ }^{30,35}$ Based on this, we designed analogs in which each aromatic ring hydrogen atom of GAT211 was replaced with a fluorine atom one at a time at a various position on sites I, II and III of GAT211. The functional activity of 10 such mono-fluorinated analogs (Table 1) further guided the design of four di-fluorinated and four tri-fluorinated analogs (Table 1). Likewise, substitution of $\mathrm{CH}$ groups with nitrogen in (hetero-)aromatic rings, termed "nitrogen walk" or aza walk (Nwalk), can enhance the physicochemical and pharmacological properties of a drug, mainly by altering intramolecular and/or ligand-GPCR noncovalent interactions to effect positive conformational change upon the ligand and/or liganded GPCR. ${ }^{34,}{ }^{36}$ Introduction of a basic nitrogen atom into a ring generally decreases lipophilicity and increases the compound's volume of distribution, thereby prolonging its serum half-life and inviting the prospect of once-daily oral dosing. ${ }^{34}$ Thus, we designed 10 aza-analogs of GAT211, one of which could not be synthesized and isolated due to its instability. We also designed a representative hybrid analog in which both nitrogen and fluorine atoms were incorporated together at the most-tolerable positions in the same ring. All analogs retained the GAT211 nitro 
functionality, as its substitution with different groups (e.g., amino, acid, cyano, hydroxyl, trifluoromethyl) compromised pharmacological activity. ${ }^{23,61}$ The aliphatic nitro group was well tolerated and did not cause apparent toxicity in the several animal models in which GAT211 was profiled. ${ }^{27-29}$

\section{RESULTS AND DISCUSSION: CHEMISTRY:}

The positional variation of fluorine at the Site III was accomplished according to Scheme 1 . Different fluorinated $\beta$-nitrostyrenes (2a-d) were synthesized as reported ${ }^{37}$ from each corresponding mono-substituted fluoro-benzaldehydes (1a-d). These nitrostyrenes were further treated for Michael addition with 2-phenyl indole (5) based on our in-house developed synthetic methodology ${ }^{38}$ to furnish target compounds 6a-d in good yields.

Similarly, a positional variation of fluorine at the Site I was accomplished according to Scheme 2. Commercially available fluoro-substituted indoles (3e-h) were coupled with phenyl boronic acid under a Suzuki type reaction condition ${ }^{39}$ in the presence of $\mathrm{Pd}(\mathrm{OAc})_{2}$ in acetic acid under an oxygen atmosphere to yield fluorinated indoles (5e-h) in good yields (51\%-67\%). Similarly, indoles $\mathbf{5 i - k}$ were synthesized by coupling commercially available fluoro phenylboronic acid 4i-k with 2-phenylindole in good yields. All synthesized monofluoro 2-phenylindoles (5e-k) were treated with $\beta$-nitrostyrene and trifluoro ammonium acetate under microwave irradiation to furnish the corresponding Michael adducts $\mathbf{6 e - k}$ in $51-85 \%$ yields.

Difluoro-substituted analogs (61-6o) were synthesized from $\mathbf{5 g}$ and $\mathbf{5 h}$ with 2-F and 4Fnitrostyrene (2a and $\mathbf{2 c}$ ), respectively, using the same strategy (Scheme 2). Trifluorinated analogs (6p-6s) were synthesized by following the same protocol that involved difluoro indoles (5l-5m) and the corresponding fluoro nitrostyrene (2a and $\mathbf{2 c}$ ).

For nitrogen-walk analogs at Site III, we synthesized the corresponding pyridine nitrostyrenes $8 \mathbf{a c}$ by following the reported protocol ${ }^{40,41,48}$ which involved nitro-aldol condensation of nitromethane and pyridine aldehyde 7a-c under basic condition followed by dehydration. Michael adducts 9a-c were obtained in good yields by treating pyridine nitrostyrenes 8a-c with 2-phenylindole in the presence of $\mathrm{nBu}_{4} \mathrm{NI}^{41}$ On the other hand, pyridinyl indoles 11a-c were synthesized by using a Fisher indole synthesis strategy. This involved synthesis of phenylhydrazones from pyridine aldehydes 10b-c and phenylhydrazine followed by their intramolecular cyclization in the presence of PPA to yield corresponding indoles. ${ }^{42}$ Indoles 11b-c were treated with $\beta$-nitrostyrene in the presence of $\mathrm{Et}_{4} \mathrm{NBr}$ in dioxane: water (9:1) under reflux condition to yield Michael adducts 9d-e in good yields (Scheme 3). We were not able to isolate the Michael adduct product derived from indole 11a and $\beta$-nitrostyrene under various attempted conditions, presumably due to its instability. The aza-indoles required for the synthesis of nitrogen-walk analogs at Site I were obtained using different synthetic strategies (Scheme 4). Thus 4- and 6-aza-2-phenylindole 11d and 11f respectively were synthesized by treating 2-methylpyridin-3-amine 12 and 4methylpyridin-3-amine 14 with ethyl benzoate and sec-BuLi. ${ }^{43}$ For the synthesis of 5-aza-2phenyl-1H-indole 11e, we used Sonogashira coupling followed by a 5 -endo-dig cyclization 
strategy. ${ }^{44}$. Accordingly, 3-iodopyridin-4-amine 13 was treated with phenyl acetylene, $\mathrm{Pd}\left(\mathrm{PPh}_{3}\right)_{4}, \mathrm{CuI}$ in DMF to obtain the aryl-alkyne coupled product ${ }^{45}$, which was further cyclized with $\mathrm{KO}^{\mathrm{t}} \mathrm{Bu}$ to obtain the 4-aza-2-phenyl indole $\mathbf{1 1}^{46}$ in $84 \%$ overall yield. When 4-methylpyridin-3-amine was treated with ethyl benzoate for one-pot indole formation, we obtained the corresponding amide compound $\mathbf{1 5}$, which was purified and then cyclized with sec-BuLi to yield 7 -aza indole $\mathbf{1 1 g}$ in $51 \%$ yield.

Once all corresponding aza-indoles were prepared for the synthesis of Site I variation analogs, we attempted our earlier developed method ${ }^{38}$ or other literature reported conditions for the Michael addition reaction between 2-phenyl aza-indoles and $\beta$-nitrostyrene.

However, for aza-indoles, these approaches failed to produce the corresponding aza Michael adducts, a likely reflection of nitrogen's inductive effect, which makes the indole ring electron deficient and less reactive.

To increase the indole ring's electron density and foster the likelihood of its participating in Michael addition with nitrostyrene, we generated the corresponding indolium anions by treating the aza-indoles with a strong base $\left(\mathrm{NaH}, \mathrm{KO}{ }^{\mathrm{t}} \mathrm{Bu},{ }^{\mathrm{n}} \mathrm{BuLi}\right) .{ }^{47}$ We observed that this objective was best achieved with ${ }^{\mathrm{n}} \mathrm{BuLi}$. The indolium anion was then reacted in situ with nitrostyrene, and the corresponding Michael adduct was isolated in moderate to good yields (Scheme 5). This approach represents a novel and useful strategy to synthesize Michael adducts between electron deficient indoles and $\beta$-nitrostyrene. Using this optimized reaction condition, we synthesized the desired aza-derivatives 9f-i (Scheme 4) in moderate to good yields.

For the synthesis of the fluoro-aza hybrid compound $\mathbf{9 j}$, the nitrostyrene $\mathbf{8 d}$ was synthesized from 6-fluoropicolinaldehyde $\mathbf{7 d}$. Aldehyde $\mathbf{7 d}$ was treated with nitromethane and $\mathrm{KO}^{\mathrm{t}} \mathrm{Bu}$ to obtain corresponding nitro alcohol, which was further dehydrated with $\mathrm{Ac}_{2} \mathrm{O} / \mathrm{DMAP}$ to get nitrostyrene $8 \mathbf{d}$ in good yield. ${ }^{48}$ Nitrostyrene $8 \mathbf{d}$ was treated with 2-phenylindole with $\mathrm{CF}_{3} \mathrm{COONH}_{4}$ under reflux to obtain the corresponding Michael adduct $\mathbf{9 j}$ in $90 \%$ yield (Scheme 6).

STRUCTURE-ACTIVITY RELATIONSHIP STUDIES: The influence of fluorine- and nitrogen-walks on biological activity of GAT211 was indexed in vitro as CB1R-dependent PAM inhibition of cAMP formation and $\beta$ arrestin2 recruitment in Chinese hamster ovary (CHO) cells stably-expressing hCB1R (DiscoveRx HitHunter and PathHunter, respectively) + CP55,940 $\left(\mathrm{EC}_{20}\right)$ according to previously described methods (Table 1 and 2). ${ }^{25}$ Cellular cAMP formation reflects $\mathrm{G}$ protein-mediated signaling, whereas $\beta$ arrestin2 recruitment reflects $\mathrm{G}$ proteinindependent information pathways. ${ }^{25}$ In the cAMP assay, inhibition of forskolin-stimulated cAMP is quantified through the production of a chemiluminescent signal in the HitHunter cell line proportional to cAMP abundance. ${ }^{25}$ Similarly, $\beta$ arrestin2 recruitment is quantified in the PathHunter assay through $\beta$ arrestin2 enzyme complementation between CB1R and $\beta$ arrestin2, each of which is expressed as a fusion protein with a fragment of $\beta$-galactosidase, thus interaction between CB1R and $\beta$ arrestin2 yields a complete enzyme whose activity is quantified via detection of a chemiluminescent signal. ${ }^{25}$ Previous data have shown that $\mathrm{G}$ protein-mediated signaling via CB1R is associated with sustained CB1R levels and cellular viability, whereas $\beta$ arrestin2 recruitment 
is associated with downregulation of CB1R and reduced cell viability. ${ }^{29}$ Thus, ideal candidate compounds are likely to display high potency and efficacy for $\mathrm{G}$ protein-mediated effects relative to $\beta$ arrestin2 recruitment. Our data thus provide insight into the bioactivity of our newly synthesized compounds on the two principal mechanisms of GPCR/CB1R signaling. The comprehensive in vitro SAR in these cell-based assays for GAT211 congeners obtained from the fluorine-walk are given in Table 1, and those from nitrogenwalk are shown in Table 2.

In comparison to parent compound $\mathbf{6 d}$, introduction of fluorine at C4, C5, C6 and C7 positions of the indole ring at Site I (6e-h) showed incrementally improved PAM activity in the cAMP assay with modest, if any, influence on $\beta$ arrestin2 recruitment. Among these, $\mathbf{6 g}$ (cAMP: $\mathrm{EC}_{50}=110 \mathrm{nM}, E_{\max }=120 \% ; \beta$ arrestin2: $\mathrm{EC}_{50}=1,100 \mathrm{nM}, E_{\max }=38 \%$ ) and $\mathbf{6 h}$, (cAMP: $\mathrm{EC}_{50}=22 \mathrm{nM}, E_{\max }=120 \%$; $\beta$ arrestin2: $\mathrm{EC}_{50}=750 \mathrm{nM}, E_{\max }=45 \%$ ), exhibited improved potency and signaling selectivity.

Compounds 6i-k were derived from the fluorine-atom introduction at the ortho-, meta-, and para-positions of the phenyl ring at the $\mathrm{C} 2$ position of indole (Site II). All analogs retained PAM activity in the cAMP and $\beta$ arrestin2 assays, and the meta-fluoro analog $6 \mathbf{j}$ (cAMP: $\mathrm{EC}_{50}=80 \mathrm{nM}, E_{\max }=140 \% ;$;arrestin2: $\left.\mathrm{EC}_{50}=1,300 \mathrm{nM}, E_{\max }=55 \%\right)$ displayed improved potency relative to the parent compound $\mathbf{6 d}$ and selectivity for cAMP relative to ßarrestin2 recruitment.

The remaining fluorine-analogs of this "fluoro-walk" series reflect the introduction of fluorine-atom into the phenyl ring (Site III). Intriguingly, all analogs (6a-c) showed significant variation in PAM activity. Ortho-fluoro-substitution at Site III, 6a (cAMP: EC 50 $=43 \mathrm{nM}, E_{\max }=110 \%$; $\beta$ arrestin2: $\mathrm{EC}_{50}=1,060 \mathrm{nM}, E_{\max }=63 \%$ ), was more potent than parent compound $\mathbf{6 d}$ and somewhat selective for cAMP relative to $\beta$ arrestin2. Meta- and para- fluorine substitution at this site led to analogs with decreased PAM activity ( $6 \mathbf{6}$ and 6c).

These GAT211 fluoro-walk data demonstrate the importance of the fluorine moiety and identified positions of active sites in each of the parent compound's rings (Sites I, II, and III) that can tolerate substitution without compromising biological activity as CB1R PAMs and, in some cases, that enhance activity and alter signaling bias between cAMP vs. $\beta$ arrestin2 recruitment.

To evaluate the potential for the cumulative effect of multiple fluoro-substitutions that were well tolerated at each site studied, we synthesized a series of four di-fluoro GAT211 analogs (61-o). The di-fluoro analogs $\mathbf{6}$ and $\mathbf{6 m}$ were more potent and efficacious hCB1R PAMs than the parent compound $\mathbf{6 d}$ and retained cAMP-selectivity, with $\mathbf{6 m}$ (C7 fluorinated analog) the more-potent of the two. In contrast difluoro analogs $\mathbf{6 n}$ (cAMP: $\mathrm{EC}_{50}=1,300$ $\mathrm{nM}, E_{\max }=47 \%$, Barrestin2: $\left.\mathrm{EC}_{50}=1,100 \mathrm{nM}, E_{\max }=32 \%\right)$ and $60\left(\mathrm{cAMP}: \mathrm{EC}_{50}=270\right.$ $\mathrm{nM}, E_{\max }=121 \%$, קarrestin2: $\mathrm{EC}_{50}=700 \mathrm{nM}, E_{\max }=27 \%$ ) exhibited reduced activity. The tri-fluoro analogs 6r (cAMP: $\mathrm{EC}_{50}=28 \mathrm{nM}, E_{\max }=93 \%$; $\beta$ arrestin2: $\mathrm{EC}_{50}=750 \mathrm{nM}, E_{\max }$ $=71 \%$ ) and $6 \mathbf{s}$ (cAMP: $\mathrm{EC}_{50}=9.1 \mathrm{nM}, E_{\max }=93 \%$; ßarrestin2: $\mathrm{EC}_{50}=510 \mathrm{nM}, E_{\max }=$ 
$82 \%$ ), were highly potent and fully efficacious CB1R PAMs relative to $\mathbf{6 d}$ with notable bias towards cAMP inhibition relative to $\beta$ arrestin2 recruitment.

Unlike $\mathbf{6 r}$ and $\mathbf{6 s}$, the tri-fluoro analogs $\mathbf{6 p}$ and $\mathbf{6 q}$ (para-substitution at Site III) exhibited unaltered or reduced PAM activity relative to parent compound $\mathbf{6 d}$. These combined data are congruent with the SAR of the mono-fluoro and di-fluoro analogs and lead to the general conclusion that fluoro-substitution at the para-position of Site III on the GAT211 scaffold is poorly tolerated.

Similar to GAT211 (6d), some 40-70\% of active pharmaceuticals exhibit poor aqueous solubility, a property which would compromise oral bioavailability without, for example, a suitable excipient or delivery system such as those that have been recognized and approved by regulatory authorities. ${ }^{49}$ With this in mind, we synthesized and profiled several nitrogenwalk analogs of $\mathbf{6 d}$ for their PAM activity in the cAMP-inhibition and $\beta$ arrestin2recruitment assays and calculated their solubility with the aim of reducing lipophilicity (i.e., improving aqueous solubility) while maintaining, if not improving, potency (Table 3).

The lack of activity exhibited by all aza compounds $9 f-i$ at Site I indicates that the polarity of the nitrogen substitution in Site I is not tolerated, suggesting that this region of the molecule interacts with hydrophobic residues in hCB1R. Notably, compound $9 \mathbf{i}$ demonstrated a huge increase in aqueous solubility compared to any other aza-analog from this series.

Similarly, aza-substitution of the aromatic ring at Site II (9d, 9e) reduced potency and efficacy relative to the GAT211 parent 6d. Among the Site III aza analogs tested, 9a (orthosubstitution) was the only analog that retained hCB1R PAM potency or efficacy in the cAMP inhibition assay (cAMP: $\mathrm{EC}_{50}=260 \mathrm{nM} ; E_{\max }=130 \%$; $\beta$ arrestin2: $\mathrm{EC}_{50}>10 \mu \mathrm{M}$ ) compared to 6d. Whereas other Site-III aza substitutions were not well tolerated $(\mathbf{9 b}, \mathbf{9 c})$.

A fluoro-aza-hybrid compound $(\mathbf{9 j}$ ) was synthesized bearing the well-tolerated Site-III aza orthosubstitution observed in 9a and the fluoro ortho-substitution observed in 6a. However, $\mathbf{9 j}$ displayed reduced potency and efficacy in both cAMP and $\beta$ arrestin 2 assays compared to parent 6d and both 6a and 9a (Table 2). Interestingly, it had improved aqueous solubility over the parent compound $\mathbf{6 d}$. In comparison with parent compound GAT211, there was also a significant decrease in the liver microsomal clearance of compound $\mathbf{6 s}$ in both human and rat (Table 3). Thus, these functional activity-based SAR study identified, the two tri-fluoro compounds $\mathbf{6 r}$ and $\mathbf{6 s}$ as the potent CB1R ago-PAMs with improved metabolic stability and compound $\mathbf{9 j}$ as a moderate PAM with improved aqueous solubility over the parent compound $\mathbf{6 d}$.

\section{Further in vitro and in vivo Characterization:}

Agonism and positive allosteric modulation in HEK293 cells: Following our initial SAR assessment, the key analogs $\mathbf{6 r}, \mathbf{6 s}$, and $\mathbf{9 j}$ were characterized for cAMP inhibition in HEK293 cells stably expressing GFP-tagged rat CB1R (GFP-rCB1R). As with our initial assessment, cells were treated with compound for $30 \mathrm{~min}$; unlike the initial assessment, however, cAMP levels were quantified via time-resolved fluorescence resonance energy 
transfer (TR-FRET) in a distinct cell line for both agonist activity (Fig. 2) and concentrationdependent PAM activity (Table 4; Fig. 3).

Compounds $\mathbf{6 r}$ and $\mathbf{6 s}$ both displayed greater potency and efficacy as allosteric agonist than the parent compound $\mathbf{6 d}$ for cAMP inhibition (Table 4; Fig. 2). 9j displayed greatly reduced agonist activity relative to GAT211 (Table 4; Fig. 2) as observed in the initial assessment. Increasing concentrations of all ago-PAMs produced a demonstrable downward and leftward shift in the CP55,940-dependent concentration-response curve, as expected for a CB1R agoPAM. The magnitude of both potency and efficacy shift was greatest for $\mathbf{6 r}$ and $\mathbf{6 s}$ and least for $\mathbf{9 j}$ (Table 4; Fig. 3). For both agonist and PAM activity evaluations, $6 \mathbf{s}$ was slightly, but not significantly, more potent than $\mathbf{6 r}$, which was consistent with initial SAR evaluations (Tables 1, 2).

Radioligand binding and GTP $\boldsymbol{\gamma}$ S assay: The parent compound GAT211 (6d) was previously shown to enhance the binding of $\left[{ }^{3} \mathrm{H}\right] \mathrm{CP} 55,940$ and reduce the binding of $\left[{ }^{3} \mathrm{H}\right] \mathrm{SR} 141716 \mathrm{~A}$ at hCB1R in membranes isolated from CHO cells stably-expressing hCB1R. ${ }^{25}$ This paradoxical enhancement of agonist binding and displacement of antagonist binding has been observed for all other CB1R allosteric modulators described to date, including the NAMs Org27569 and PSNCBAM-1. The tri-fluorinated compounds $\mathbf{6 r}$ and $\mathbf{6 s}$ reduced $\left[{ }^{3} \mathrm{H}\right] \mathrm{SR} 141716 \mathrm{~A}$ binding at hCB1R with low nanomolar affinities of $4.8 \mathrm{nM}$ and 5.2 $\mathrm{nM}$, respectively (Fig. 4a) in accordance with their high potency and efficacy in vitro (Table 1). The aza-fluoro-hybrid $9 \mathbf{j}$ reduced $\left[{ }^{3} \mathrm{H}\right] \mathrm{SR} 141716 \mathrm{~A}$ binding in the micromolar range $(2.3$ $\mu \mathrm{M}$; Fig. 4a). Compounds $\mathbf{6 r}, \mathbf{6 s}$, and $\mathbf{9 j}$ enhanced $\left[{ }^{3} \mathrm{H}\right] \mathrm{CP} 55,940$ binding to hCB1R similar to $\mathbf{6 d}\left(K_{\mathrm{i}}=88 \mathrm{nM}\right.$ for $\mathbf{6 r}, K_{\mathrm{i}}=94 \mathrm{nM}$ for $\mathbf{6 s}, K_{\mathrm{i}}=110 \mathrm{nM}$ for $\mathbf{9 j}$ ) (Fig. 4b). Compounds $\mathbf{6 r}$, $\mathbf{6 s}$, and $\mathbf{9 j}$ at $1 \mu \mathrm{M}$ concentration significantly increased CP55,940-dependent G-protein coupling (0.1 and $1 \mathrm{nM})$ (Fig. 4c). Both $6 \mathbf{r}$ and $\mathbf{6 s}$ enhanced G-protein coupling with nanomolar potency $\left(\mathrm{EC}_{50}=47 \mathrm{nM}\right.$ for $\mathbf{6 r}, K_{\mathrm{i}}=33 \mathrm{nM}$ for $\left.\mathbf{6 s}\right)$, whereas $\mathbf{9 j}$ was less potent than the parent compound $\left(\mathrm{EC}_{50}=170 \mathrm{nM}\right.$ for $\mathbf{9 j}$ ) when tested alone (Fig. $\left.4 \mathrm{~d}\right)$. These data support a SAR-driven correlation between potent CB1R PAM activity, enhancement of agonist binding, and reduction of antagonist binding.

Agonism, positive allosteric modulation, and bias in $\mathrm{CHO}$ cells: Our initial assessments of CB1R-dependent PAM activity utilized a high throughput screening approach to gather preliminary data in the presence of CP55,940 at $\mathrm{EC}_{20}$ for cAMP inhibition at $30 \mathrm{~min}$ and $\beta$ arrestin2 recruitment at $90 \mathrm{~min}$. Given the potential for our compounds to exhibit mixed agonist/PAM activity (i.e. ago-PAMs), it was important to assess their bias and PAM activity at a higher concentration of orthosteric agonist, because the bias activity of PAMs - particularly ago/PAMs - may change as a function of orthosteric agonist concentration. ${ }^{50}$ Further, we needed to have greater statistical power for assessing ligand bias between cAMP inhibition and $\beta$ arrestin2 recruitment. Therefore, the lead agoPAMs $(\mathbf{6 r}, \mathbf{6 s}$, and $\mathbf{9 j}$ ) were assessed with greater power $(n \geq 6)$ (i) alone to quantify intrinsic agonist activity, (ii) in the presence of $100 \mathrm{nM} \mathrm{CB1R}$ agonist $(\mathrm{CP} 55,940)$ to determine the extent of PAM enhancement at greater orthosteric agonist concentrations, (iii) at matched time points (90 min for both cAMP inhibition and ßarrestin2 recruitment), and (iv) for signaling bias. cAMP inhibition data were normalized to \% compound maxima for each 
respective compound in order to fit data to the operation model and estimate signaling bias (Table 4; Fig. 5).

Compounds $\mathbf{6 r}, \mathbf{6 s}$, and $\mathbf{9 j}$ each directly activated CB1R-dependent cAMP inhibition (90 min), with $\mathbf{6 s}$ having greater potency than $\mathbf{6 r}$, and $\mathbf{9 j}$ displaying low potency (Table 4; Fig. 5a). 6r, 6s, and 9j minimally enhanced CB1R-dependent $\beta$ arrestin 2 recruitment alone (Table 4; Fig. 5b). When these data were fit to the operational model, $\mathbf{6 r}$ and $\mathbf{6 s}$ displayed agonist bias toward cAMP inhibition in a similar manner to the parent compound $\mathbf{6 d}$ (Table 5; Fig.

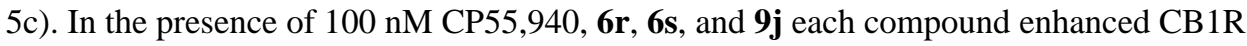
agonist-dependent cAMP inhibition with $\mathbf{6 r}$ and $\mathbf{6 s}$ displaying low nanomolar potency exceeding that of CP55,940 (Table 4; Fig. 5d).

In the presence of $100 \mathrm{nM} \mathrm{CP55,940} \mathrm{and} \mathrm{at} 90 \mathrm{~min}, \mathbf{6 r}$ and $\mathbf{6 s}$ promoted CP55,940dependent $\beta$ arrestin 2 recruitment at concentrations $\geq 190 \mathrm{nM}$ and $3.5 \mu \mathrm{M}$, respectively, whereas $9 \mathbf{j}$ did not (Table 5; Fig. 5e). From these data, $\mathbf{6 r}$ and $\mathbf{6 s}$, but not $\mathbf{9 j}$, display bias toward cAMP inhibition when CP55,940 is the agonist similar to the parent compound $\mathbf{6 d}$ (data fit to operational model; Table 5; Fig. 5f). These data show $\mathbf{6 r}$ and $\mathbf{6 s}$ as being highly biased for cAMP inhibition at high orthosteric agonist concentrations and matched time points, and that their PAM activity is demonstrable across a wide range of orthosteric agonist concentrations. ${ }^{49}$ The observed cAMP inhibition signaling bias of $\mathbf{6 r}$ and $\mathbf{6 s}$ has important potential biological implications because $\mathrm{Ga}_{\mathrm{i} / \mathrm{o}}$-biased inhibition of cAMP has previously been shown to enhance CB1R-dependent cell viability whereas $\beta$ arrestin2-biased ligand treatment is associated with CB1R downregulation and reduced cell viability. ${ }^{29}$ Thus, the observed bias in favor of cAMP inhibition of $\mathbf{6 r}$ and $\mathbf{6 s}$ may be an advantageous property of these compounds. Data for compounds $\mathbf{6 r}$ and $\mathbf{6 s}$ are in accordance with observations made in our initial high thru-put screen, radioligand binding, $G$ protein-coupling, and cAMP inhibition in HEK293 cells because each compound consistently displayed ago-PAM activity and $\mathbf{6 s}$ was consistently and slightly more potent. Compound $\mathbf{9 j}$ displayed greater PAM potency in HEK293 cell cAMP inhibition (Table 4; Fig. 3) and CHO cell $\left[{ }^{35} \mathrm{~S}\right] \mathrm{GTP} \gamma \mathrm{S}$ and cAMP inhibition assays with a longer treatment time and higher CP55,940 concentration (Table 5; Fig. 4, 5) than in our initial screen (Table 2). These distinctions likely reflect inter-assay differences in ligand equilibration time, orthosteric ligand concentration, and receptor density and serve to underscore the importance of thoroughly profiling novel allosteric ligands in multiple assay systems. ${ }^{19,25,50}$ Moreover, the ability of 6r and $\mathbf{6 s}$ to produce CB1R PAM effects over a wide range of agonist concentrations, with multiple orthosteric agonists utilized throughout our study, and in different model systems, are evidence for robust modulatory activity which is not limited by probe dependence or a narrow orthosteric agonist concentration range. ${ }^{25,29}$

\section{Electrophysiology Characterization of three ago-PAMs in autaptic hippocampal neurons: We made use of cultured excitatory autaptic hippocampal} neurons. We have previously shown that these neurons can be stimulated to produce depolarization-induced suppression of excitation (DSE), a form of retrograde inhibition that is mediated by endocannabinoid 2-AG, and that requires $\mathrm{CB} 1 \mathrm{R}^{51}$. Because 2-AG is not tonically released in autaptic neurons ${ }^{51}$, a PAM is not expected to directly inhibit synaptic 
transmission but should enhance the 2-AG mediated DSE response. We found that $\mathbf{6 r}$ and $\mathbf{6 s}$ strongly inhibited excitatory postsynaptic currents (EPSCs) independent of endocannabinoid production in all autaptic neurons that tested (Fig. 6A,F, Relative EPSC charge after 6r $(1 \mu \mathrm{M}): 0.52 \pm 0.11, \mathrm{n}=4 ; \mathbf{6 s}(1 \mu \mathrm{M}): 0.49 \pm 0.05, \mathrm{n}=5 ; \mathrm{p}<0.05$, one-tailed $t$-test vs. 1.0$)$. This substantial inhibition of EPSCs by $6 \mathbf{r}$ and $\mathbf{6 s}$ occluded cannabinoid signaling and is consistent with action as an agonist. In contrast, $\mathbf{9 j}$ also directly inhibited EPSCs, but to a lesser extent than $\mathbf{6 r}$ or $\mathbf{6 s}$ (Fig. 6C, Relative EPSC charge after $\mathbf{9 j}(1 \mu \mathrm{M})$ in WT: $0.70 \pm$ $0.09, \mathrm{n}=5 ; \mathrm{p}<0.05$, one-tailed t test vs. 1.0). Because $\mathbf{9 j}$ did not fully occlude DSE, we were able to assess the impact of $\mathbf{9 j}$ on DSE responses (e.g., Fig. 6E), finding that DSE was enhanced by $\mathbf{9 j}$. This signaling profile of EPSC inhibition combined with enhancement of DSE is consistent with action as an ago-PAM.

In vivo effects of $9 \mathrm{j}$ on the modulation of intraocular pressure: Cannabinoids and endocannabinoids that activate CB1R such as THC, CP55,940, WIN55,212-2 (WIN) and 2AG produce a reduction in IOP. ${ }^{52-54}$ We tested the ability of $\mathbf{9 j}$ to modulate IOP in ocular normotensive and hypertensive NEE mice. The NEE mice have a 1 base pair deletion in $S h 3 p x d 2 b$ gene, and exhibit several structural deformities, that also affect the eyes and lead to the development of elevated IOP. The effect of $\mathbf{9 j}$ was tested at 1,6 , and 12 hours following topical administration in both normotensive and NEE, as we previously demonstrated that another PAM GAT229 lowers IOP at these time points. ${ }^{28}$ We also used the orthosteric CB1 ligand WIN both alone or administered in combination with $\mathbf{9 j}$, to determine whether IOP reduction is mediated through CB1R. Previous studies in ocular normotensive animals demonstrated that the subthreshold concentration of topically applied CB1 ligand WIN (0.25\%) does not affect IOP, while 1\% WIN decreases IOP; however, this effect is short lasting. ${ }^{28}$ In this study, we showed that when subthreshold $0.25 \%$ WIN was co-administered with $0.2 \% \mathbf{9 j}$ the IOP was significantly reduced at all time points tested $(\mathrm{P}<$ $0.05,-0.7 \pm 0.2,-0.6 \pm 0.3$ and $0.1 \pm 0.2 \mathrm{mmHg}$ from baseline, respectively, $\mathrm{n}=5$; Figure 7A). To determine whether $\mathbf{9 j}$ will be effective in the reduction of IOP under pathological conditions, where endocannabinoid tone may be altered, i.e., increased, we used ocular hypertensive NEE mice. ${ }^{52,55-57}$ Topical $0.2 \%$ 9j alone significantly decreased IOP at $1-$ and 6-hours post-administration $(\mathrm{P}<0.05,-2.5 \pm 1$ and $-3.6 \pm 1 \mathrm{mmHg}$ from baseline, $\mathrm{n}=5$; Figure 7B) and was no longer present at 12 hours. This finding indicates that $9 \mathbf{j}$ potentiates the effect of WIN and prolongs its action in normotensive mice, and additionally that $\mathbf{9 j}$ is able to directly reduce IOP in a pathological setting in the ocular hypertensive NEE mice.

In vivo testing of $6 r$ and 6 s in an animal model of pain: Complete Freund's adjuvant (CFA) reduced mechanical paw withdrawal thresholds in the injected paw, consistent with the development of mechanical allodynia $\left(\mathrm{F}_{2,15}=43.008 p=0.001\right.$; Fig. 8A). Both $6 \mathbf{r}$ and $6 \mathbf{s}$ dose-dependently increased mechanical paw withdrawal thresholds in the CFA-injected (ipsilateral) paw $\left(\mathrm{F}_{14,105}=6.451, p=0.001\right.$; Fig. 8A) without altering paw withdrawal thresholds in the contralateral paw $\left(\mathrm{F}_{2,15}=1.325 p=0.295\right.$; Fig. 8B $)$. Doses of $6 \mathbf{r}$ and 6s, ranging from 3-30 mg/kg i.p. elevated mechanical paw withdrawal thresholds relative to groups receiving the vehicle at the same times (Fig. 8A; $\mathrm{p}<0.05$ for each comparison). Moreover, doses of $6 \mathbf{r}$ and $\mathbf{6 s}$ below $0.3 \mathrm{mg} / \mathrm{kg}$ i.p. did not alter mechanical paw withdrawal thresholds relative to vehicle $(\mathrm{p} \searrow 0.229)$ (Fig. 8A). Both $6 \mathbf{r}$ and $\mathbf{6 s}$, at doses 
of $30 \mathrm{mg} / \mathrm{kg}$ i.p., maximally suppressed CFA-induced inflammatory pain and, consequently, the duration of action was evaluated using this dose. Both $6 \mathbf{r}$ and $\mathbf{6 s}(30 \mathrm{mg} / \mathrm{kg}$ i.p.) increased mechanical paw withdrawal thresholds in a time-dependent manner in the CFAinjected paw (F2, 14=26.322, $p=0.001$; Fig. 8C) without altering paw withdrawal thresholds in the contralateral paw (Fig. 8D). Bonferroni post hoc tests revealed that both $6 \mathbf{r}(30 \mathrm{mg} / \mathrm{kg}$ i.p.) and $\mathbf{6 s}(30 \mathrm{mg} / \mathrm{kg}$ i.p.) increased mechanical paw withdrawal threshold at $30 \mathrm{~min}$ postinjection $(\mathrm{p}<0.001)$ but anti-allodynic efficacy was no longer present at $4 \mathrm{~h}$ post injection compared with the vehicle group ( $p=1$ for $\mathbf{6 r} ; p=0.107$ for $\mathbf{6 s}$, respectively) (Fig. 8C). Post hoc comparisons failed to reveal reliable differences in mechanical paw withdrawal thresholds in the CFA-injected paw of mice receiving $6 \mathbf{r}$ and $\mathbf{6 s}$ across the entire observation interval. Planned comparisons, nonetheless, revealed that $\mathbf{6 s}$ produced greater anti-allodynic efficacy than $\mathbf{6 s}$ at $4 \mathrm{~h}$ post injection ( $p=0.006$; two-tailed t-test), suggesting that $6 \mathbf{s}$ may exhibit a longer duration of action relative to $6 \mathbf{r}$. Neither $6 \mathbf{r}(30 \mathrm{mg} / \mathrm{kg}$ i.p.) nor $6 \mathbf{s}(30 \mathrm{mg} / \mathrm{kg}$ i.p.) suppressed CFA-induced mechanical allodynia in the ipsilateral paw of CB1KO mice $\left(F_{2}, 14=0.011, p=0.989\right.$; Fig. 8E). Thus, the antiallodynic effects of $\mathbf{6 r}$ and $\mathbf{6 s}$ in WT were dependent upon CB1R activation. None of the pharmacological manipulations altered mechanical paw withdrawal thresholds in the contralateral paw in either WT $\left(\mathrm{F}_{2,14}=0.341\right.$ $p=0.717$; Fig. E) or CB1 KO animals $\left(\mathrm{F}_{2,14}=0.015 p=0.985\right.$; Fig. $\left.8 \mathrm{~F}\right)$.

Our studies suggest that the CB1R ago-PAMs 6r and 6s suppress established mechanical allodynia in the CFA model of inflammatory nociception. Both compounds attenuated behavioral hypersensitivity induced by the inflammatory challenge in the ipsilateral paw, without altering basal nociceptive thresholds in the non-injected contralateral paw. These observations indicate that the CB1R ago-PAMs reversed sensitization without producing analgesia, consistent with our previous observations using $\mathbf{6 d}$ in the same pain model. ${ }^{27}$ Moreover, anti-allodynic efficacy was mediated by CB1R for each ligand. Neither $6 \mathbf{r}$ nor $\mathbf{6 s}$ altered mechanical paw withdrawal thresholds in CB1R KO mice, demonstrating that antiallodynic efficacy was dependent upon CB1R activation. Moreover, CB1R KO mice showed the characteristic development of CFA-induced allodynia, consistent with our previously published work ${ }^{58,59}$. Both $\mathbf{6 r}$ and $\mathbf{6 s}$ exhibit a longer duration of anti-allodynic efficacy than 6d. ${ }^{60}$. We previously reported that the anti-allodynic efficacy of $\mathbf{6 d}$ was maximal at 30 min post-injection, present at $1.5 \mathrm{~h}$ but absent at $2.5 \mathrm{~h}$ post injection in the same CFA model of inflammatory nociception. ${ }^{27}$ Post hoc comparisons failed to reveal differences between $\mathbf{6 s}$ and $\mathbf{6 r}$ in our study, suggesting that the compounds showed similar efficacies and time courses. However, at $2.5 \mathrm{~h}$ post injection $\mathbf{6 s}$ exhibited greater antinociceptive efficacy than $\mathbf{6 r}$, which could reflect a longer duration of action of $\mathbf{6 s}$ versus $\mathbf{6 r}$.

\section{In vivo assessment - Catalepsy, Hypothermia, and Anti-nociception Tests-}

Male C57BL/6 mice were treated with increasing doses of $\mathbf{6 r}, \mathbf{6 s}$, or $9 \mathbf{j}$ to determine whether these compounds produced acute catalepsy, hypothermia, or anti-nociceptive effects.

Previous studies have demonstrated cannabimimetic effects are sufficiently observed without open field assessment; therefore, locomotor effects were not assessed minimize animal handling and stress. ${ }^{22,66} \mathbf{6 r}, \mathbf{6 s}$, and $\mathbf{9 j}$ did not produce catalepsy or hypothermia at $0.1,1,3$, or $10 \mathrm{mg} / \mathrm{kg}$ (i.p.) compared to vehicle (Fig. 9a,b). Doses $>10 \mathrm{mg} / \mathrm{kg}$ were not tested in order to limit animal usage. Both $\mathbf{6 r}, \mathbf{6 s}-$ but not $\mathbf{9 j}$ - produced a dose-dependent anti- 
nociceptive effect in the tail flick assay that was significant relative to the vehicle at 3 and 10 $\mathrm{mg} / \mathrm{kg}$ (Fig. 9c). Therefore, the ago-PAMs 6r and 6s appear to augment CB1R-dependent signaling in acute treatment. Anti-nociceptive effects of $\mathbf{6 d}$ were reported previously, ${ }^{27}$ and these results are consistent with the analgesic effects of $\mathbf{6 r}$ and $\mathbf{6 s}$ are reported above (Fig. 8). Because $\mathbf{6 r}$ and $\mathbf{6 s}$, but not $\mathbf{9 j}$, evoked anti-nociceptive responses, this activity may be dependent upon the weak agonist activity of these ago-PAMs, rather than PAM activity. Importantly, $\mathbf{6 r}$ and $\mathbf{6 s}$ did not evoke agonist-like responses in the catalepsy and body temperature assays at any dose tested, whereas an orthosteric agonist capable of producing CB1R-dependent intoxicating responses such as CP55,940, WIN55,212-2, THC would produce significant catalepsy and hypothermic effects at a dose of $10 \mathrm{mg} / \mathrm{kg} .{ }^{22,27,66}$ Thus, the ago-PAMs differ in their in vivo activity to orthosteric CB1R agonists.

SAR explanation using the computational model: Recently we reported the identification of distinct allosteric agonist and PAM binding sites at the CB1R using ForceBiased MMC Simulated studies. ${ }^{61}$ Our studies suggest that GAT228, CB1R allosteric agonist binds in an intracellular (IC) TMH1-2-4 exosite that would allow this compound to be an agonist as well as a PAM whereas GAT229, CB1R PAM binds to a distinct site at the extracellular (EC) ends of TMH2/3, just beneath the EC1 loop. Since we observed super enhanced allosteric agonist activity with newly synthesized compounds, we focused on binding sites of an allosteric agonist GAT228 (Figure 10). The indole 4-7 positions, Site I, face hydrophobic residues or the acyl chain region of the bilayer. The residues that line this part of the GAT228 binding pocket are L1.54, I1.57, L1.58, G2.44 and V2.48. The indole 6 position, which can accommodate a halogen atom is directly next to L1.54, I1.57, and G2.44. The indole 7 position, while able to accommodate fluorine or proton, is bounded by I1.57 and may not be able to accommodate a larger moiety. Substitution of the 4-7 position carbons with nitrogen is unfavorable. The 7 position substitution places the nitrogen between I1.57 and near the unprotonated nitrogen in the fivemembered ring of $\mathrm{H} 2.41$. The 5 position is packed tightly against hydrophobic L1.54. The 4 position is in contact with V2.48 and lipid acyl chains. Nitrogen at the 4 position may also influence the low energy preferred conformation of the ligand, since the stereocenter proton may prefer to be near the nitrogen instead of 180 degrees away.

The Site II phenyl when substituted with a meta- or para- nitrogen is unfavorable due to the nitrogen facing V4.43 or the glycerol/acyl chain region of the lower leaflet lipids. The Site III phenyl may accommodate ortho-nitrogen since it can be positioned next to the $\mathrm{CH}_{2}$ protons and not near the nitro group itself. This allows the protons on the opposite side of the ring to form a tilted-T aromatic stack with the face of W4.50. A meta-substitution has the nitrogen either facing lipid acyl chains or the face of W4.50. A para substitution has the nitrogen packed against the face of W4.50. S2.45, though near GAT228, is interacting with W4.50, occluded by F4.46 and is unavailable to the ligand. Fluorine substitutions work well on the indole since the pocket for the 4-7 positions is hydrophobic, and the substituted atom is similar in size to a proton.

The Site III phenyl with an ortho-fluoro substitution increases the positive partial charge on the protons involved with W4.50. If a meta-substitution is present, the fluorine can face away from W4.50, while a para-substitution is unable to avoid being near the face of W4.50. 
A special case of having an ortho-fluoro and ortho-nitrogen is unfavorable since the docked conformation of GAT228 will have one of the substituted atoms facing the indole pi system, and neither would prefer this. The docked conformation of that analog would have an unfavorable conformational cost. For GAT234, with the Site II phenyl having para-fluorine, the para-fluoro atom would be in the glycerol region of the bilayer, and that may not be favorable.

Conclusion: $\mathrm{CB} 1 \mathrm{R}$ is a well-established therapeutic target for the treatment of several pathologies, including pain, glaucoma, epilepsy, and neurodegenerative diseases. Despite decades of medicinal chemistry efforts and the new chemical matter so generated, orthosteric CB1R modulators (agonists, antagonists/inverse agonists) have met with disfavor due to demonstrated (pre)clinical associations with adverse events. Our previous studies established the efficacy and safety of CB1R ago-PAMs in treating neuropathic pain, glaucoma and Huntington's disease in animal models. This work focused on identifying key sites on the 2-phenylindole scaffold of GAT211 to improve mixed agonist and PAM activity (ago-PAM) and drug-like physicochemical properties. Several new GAT211 analogs reported herein showed improved solubility and ago-PAM activity with good potency, efficacy, and selectivity at sub micromolar concentrations. Two key analogs, $\mathbf{6 r}$ and $\mathbf{6 s}$, were identified as the most potent ago-PAMs ( $>50$-fold improved potency) and exhibited relative to the GAT211 lead, improved selectivity for cAMP inhibition over $\beta$ arrestin2 recruitment, enhanced microsomal stability, good in vivo potency in a preclinical inflammatory pain model, and increased duration of action. The effects of these compounds were solely mediated through CB1R, as these effects were absent in CB1KO mice. A moderately acting PAM with improved solubility, $\mathbf{9 j}$ demonstrated efficacy in reducing IOP in a murine NEE glaucoma model. Finally, using recently characterized binding site for allosteric agonism, we accounted for the observed SAR trend. These two potent CB1R ago-PAMs with improved lipophilicity and metabolic stability are currently being explored in vivo for treating select CNS disorders.

\section{EXPERIMENTAL SECTION}

\section{Materials and Methods:}

All commercial chemicals and solvents were purchased from Sigma Aldrich, Inc. (St. Louis, MO), Alfa Aesar, and Combi-blocks as reagent grade and unless otherwise specified were used without further purification. Biotage $®$ Initiator microwave system was used for the synthesis of a few of the intermediates of the final covalent probes. Reaction progress was monitored by thin-layer chromatography (TLC) using commercially prepared silica gel 60 F254 glass plates. Compounds were visualized under ultraviolet (UV) light or by staining with iodine, phosphomolybdic acid, or p-anisaldehyde reagent. Flash column chromatography was carried out on a Biotage $₫$ SP1, Biotage $₫$ Isolera, or Interchim purification unit using prepacked columns from Reveleris ${ }_{\text {, Biotage }}{ }^{\circ}$, and Luknova. Solvents used include hexanes, ethyl acetate, acetone, methanol, and dichloromethane. Characterization of compounds and their purity were established by a combination of HPLC, TLC, mass spectrometry, and NMR analyses. NMR spectra were recorded in DMSO- $\mathrm{d}_{6}$, chloroform-d, or methanol- $\mathrm{d}_{4}$, on a Varian NMR spectrometer $\left({ }^{1} \mathrm{H} \mathrm{NMR}\right.$ at $500 \mathrm{MHz}$ and 
${ }^{13} \mathrm{C}$ NMR at $125 \mathrm{MHz}$ ). Chemical shifts were recorded in parts per million ( $\delta$ ) relative to tetramethylsilane (TMS; $0.00 \mathrm{ppm}$ ) or solvent peaks as the internal reference.

Multiplicities are indicated as br (broadened), s (singlet), d (doublet), t (triplet), q (quartet), quin (quintet), sept (septet), or $\mathrm{m}$ (multiplet). Coupling constants (J) are reported in hertz $(\mathrm{Hz})$. All test compounds were greater than $95 \%$ pure as determined by LC/MS analysis performed using a Agilent Technologies 1260 Infinity reverse phase HPLC, with a dualwavelength UV-visible detector and an Agilent Technologies 6120 Quadrupole mass spectrometer (electrospray ionization). HRMS was done on SCIEX TOF/TOFTM 5800 System in a positive ion mode with delay time of 100ns. Each sample well was surveyed to find a "sweet spot", and then 400 laser pulses were averaged to generate a spectrum.

\section{General procedure for the preparation of fluorinated 2-phenylindoles $(5 \mathrm{e}-\mathrm{m})$ :}

In a $50 \mathrm{~mL}$ round bottom flask boronic acid $(5.12 \mathrm{mmol}), 1 \mathrm{H}$-indole $(3.41 \mathrm{mmol})$, palladium (II) acetate $(0.171 \mathrm{mmol})$ were taken in $10 \mathrm{~mL} \mathrm{AcOH}$. Reaction was degassed thoroughly and stirred under oxygen atmosphere (balloon pressure) for 12-24 hrs. Acetic acid was evaporated under reduced pressure and the residue was diluted with $200 \mathrm{~mL}$ ice cold water. Product was extracted in ethyl acetate. The organic layer was washed with brine and dried over anhydrous sodium sulfate, filtered and concentrated under vacuum to give crude product. The reaction mixture was purified by flash chromatography (ethyl acetate or acetone/hexane) using GRACE ${ }^{\mathrm{TM}}$ column to get pure product.

\section{4-Fluoro-2-phenyl-1H-indole (5e):}

Compound 5e was synthesized using above general procedure on $400 \mathrm{mg}$ scale and purified using $10 \%$ acetone in hexane. Yield $67 \%$ (white solid); ${ }^{1} \mathrm{H} \mathrm{NMR}\left(\mathrm{CDCl}_{3}, 500 \mathrm{MHz}\right): \delta$ 8.41(bs, 1H), $7.66(\mathrm{~d}, J=5.5 \mathrm{~Hz}, 2 \mathrm{H}), 7.45(\mathrm{t}, J=8.0 \mathrm{~Hz}, 2 \mathrm{H}), 7.35(\mathrm{t}, J=7.5 \mathrm{~Hz}, 1 \mathrm{H}), 7.18$ $(\mathrm{d}, J=7.5 \mathrm{~Hz}, 1 \mathrm{H}), 7.08(\mathrm{td}, J=5.0,7.5 \mathrm{~Hz}, 1 \mathrm{H}), 6.89(\mathrm{~d}, J=2.5 \mathrm{~Hz}, 1 \mathrm{H}), 6.79(\mathrm{dd}, J=5.5$, $10.5 \mathrm{~Hz}, 1 \mathrm{H})$

\section{5-Fluoro-2-phenyl-1H-indole (5f):}

Compound $\mathbf{5 f}$ was synthesized using above general procedure on $450 \mathrm{mg}$ scale and purified using $10 \%$ acetone in hexane. Yield $53 \%$ (white solid); ${ }^{1} \mathrm{H} \mathrm{NMR}\left(\mathrm{CDCl}_{3}, 500 \mathrm{MHz}\right): \delta$ 8.31(bs, 1H), 7.65 (d, $J=8.0 \mathrm{~Hz}, 2 \mathrm{H}), 7.46(\mathrm{t}, J=7.5 \mathrm{~Hz}, 2 \mathrm{H}), 7.35$ (tt, $J=1.5,7 \mathrm{~Hz}, 1 \mathrm{H}$ ), $7.31(\mathrm{dd}, J=3.5,9.0 \mathrm{~Hz}, 1 \mathrm{H}), 7.27(\mathrm{~d}, J=2.5 \mathrm{~Hz}, 1 \mathrm{H}), 6.93(\mathrm{td}, J=2.5,9.5 \mathrm{~Hz}, 1 \mathrm{H}), 6.78$ $(\mathrm{d}, J=2.5 \mathrm{~Hz}, 1 \mathrm{H})$.

\section{6-Fluoro-2-phenyl-1H-indole (5g):}

Compound $\mathbf{5 g}$ was synthesized using above general procedure on $450 \mathrm{mg}$ scale and purified using $10 \%$ acetone in hexane. Yield $62 \%$ (white solid), ${ }^{1} \mathrm{H} \mathrm{NMR}\left(\mathrm{CDCl}_{3}, 500 \mathrm{MHz}\right): \delta 8.32$ (bs, 1H), 7.63 (dt, $J=1.5,8.5 \mathrm{~Hz}, 2 \mathrm{H}), 7.53(\mathrm{dd}, J=5.5,9.0 \mathrm{~Hz}, 1 \mathrm{H}), 7.44$ (tt, $J=2.0,7.5$ $\mathrm{Hz}, 2 \mathrm{H}), 7.32$ (tt, $J=2.0,7.5 \mathrm{~Hz}, 1 \mathrm{H}$ ), 7.08 (dd, $J=2.5,9.5, \mathrm{~Hz}, 1 \mathrm{H}$ ), 6.89 (ddd, $J=2.5,7.0$, $11.0 \mathrm{~Hz}, 1 \mathrm{H}), 6.79(\mathrm{~d}, J=2.5 \mathrm{~Hz}, 1 \mathrm{H})$. 


\section{7-Fluoro-2-phenyl-1H-indole (5h):}

Compound $\mathbf{5 h}$ was synthesized using above general procedure on $400 \mathrm{mg}$ scale and purified using $10 \%$ acetone in hexane. Yield $51 \%$ (white solid); ${ }^{1} \mathrm{H} \mathrm{NMR}\left(\mathrm{CDCl}_{3}, 500 \mathrm{MHz}\right): \delta$ 8.41(bs, 1H), $7.60(\mathrm{~d}, J=8.0 \mathrm{~Hz}, 2 \mathrm{H}), 7.40(\mathrm{t}, J=7.5 \mathrm{~Hz}, 2 \mathrm{H}), 7.36(\mathrm{~d}, J=8.0 \mathrm{~Hz}, 1 \mathrm{H}), 7.31$ (t, $J=7.5 \mathrm{~Hz}, 1 \mathrm{H}), 7.0(\mathrm{td}, J=5.0,8.0 \mathrm{~Hz}, 1 \mathrm{H}), 6.89(\mathrm{dd}, J=7.5,11.5 \mathrm{~Hz}, 1 \mathrm{H}), 6.80(\mathrm{dd}, J=$ $1.0,2.5 \mathrm{~Hz}, 1 \mathrm{H})$.

\section{2-(2-Fluorophenyl)-1H-indole (5i):}

Compound 5i was synthesized using above general procedure on $400 \mathrm{mg}$ scale and purified using $10 \%$ acetone in hexane. Yield $43 \%$ (white solid); ${ }^{1} \mathrm{H} \mathrm{NMR}\left(\mathrm{CDCl}_{3}, 500 \mathrm{MHz}\right.$ ): $\delta 8.88$ (bs, $1 \mathrm{H}), 7.80(\mathrm{td}, J=2.0,8.0 \mathrm{~Hz}, 1 \mathrm{H}), 7.65(\mathrm{dd}, J=1.0,7.0 \mathrm{~Hz}, 1 \mathrm{H}), 7.43(\mathrm{dd}, J=1.0,7.0$ $\mathrm{Hz}, 1 \mathrm{H}), 7.30-7.26(\mathrm{~m}, 1 \mathrm{H}), 7.24-7.20(\mathrm{~m}, 2 \mathrm{H}), 7.18(\mathrm{td}, J=1.5,7.0 \mathrm{~Hz}, 1 \mathrm{H}), 7.13(\mathrm{td}, J=$ $1.0,7.5 \mathrm{~Hz}, 1 \mathrm{H}), 6.95(\mathrm{~d}, J=2.0 \mathrm{~Hz}, 1 \mathrm{H})$.

\section{2-(3-Fluorophenyl)-1H-indole (5j):}

Compound $\mathbf{5 j}$ was synthesized using above general procedure on $400 \mathrm{mg}$ scale and purified using $10 \%$ acetone in hexane. Yield $77 \%$ (off white solid); ${ }^{1} \mathrm{H}$ NMR $\left(\mathrm{CDCl}_{3}, 500 \mathrm{MHz}\right): \delta$ 8.29 (bs, $1 \mathrm{H}), 7.64(\mathrm{~d}, J=8.5 \mathrm{~Hz}, 1 \mathrm{H}), 7.44-7.37(\mathrm{~m}, 3 \mathrm{H}), 7.34(\mathrm{dt}, J=1.5,8.0 \mathrm{~Hz}, 1 \mathrm{H})$, $7.21(\mathrm{~d}, J=8.0 \mathrm{~Hz}, 1 \mathrm{H}), 7.12(\mathrm{t}, J=7.0 \mathrm{~Hz}, 1 \mathrm{H}), 7.01(\mathrm{tt},, J=1.5,7.5 \mathrm{~Hz}, 1 \mathrm{H}) ; 6.84(\mathrm{~d}, J=$ $2.0 \mathrm{~Hz}, 1 \mathrm{H})$.

\section{2-(4-Fluorophenyl)-1H-indole (5k):}

Compound 5k was synthesized using above general procedure on $450 \mathrm{mg}$ scale and purified using $10 \%$ acetone in hexane. Yield $72 \%$ (white solid); ${ }^{1} \mathrm{H} \mathrm{NMR}\left(\mathrm{CDCl}_{3}, 500 \mathrm{MHz}\right): \delta 8.24$ (bs, 1H), 7.63-7.59 (m, 3H), 7.39 (d, $J=8.0 \mathrm{~Hz}, 1 \mathrm{H}), 7.20$ (td, $J=1.5,8.0 \mathrm{~Hz}, 1 \mathrm{H}), 7.16-$ 7.11(m, $3 \mathrm{H}), 6.76(\mathrm{~d}, J=2.0 \mathrm{~Hz}, 1 \mathrm{H})$.

\section{6-Fluoro-2-(3-fluorophenyl)-1H-indole (5I):}

Compound $\mathbf{5 l}$ was synthesized using above general procedure on $1 \mathrm{gm}$ scale and purified using 5\% ethyl acetate in hexane. Yield 89\% (white solid); ${ }^{1} \mathrm{H} \mathrm{NMR}\left(\mathrm{CDCl}_{3}, 400 \mathrm{MHz}\right)$ : 8.32 (bs, $1 \mathrm{H}), 7.54(\mathrm{dd}, J=5.3,8.7 \mathrm{~Hz}, 1 \mathrm{H}), 7.44-7.37(\mathrm{~m}, 2 \mathrm{H}), 7.32(\mathrm{~d}, J=9.9 \mathrm{~Hz}, 1 \mathrm{H}), 7.09$ (d, $J=9.4 \mathrm{~Hz}, 1 \mathrm{H}), 7.04-7.00(\mathrm{~m}, 1 \mathrm{H}), 6.91(\mathrm{t}, J=9.6 \mathrm{~Hz}, 1 \mathrm{H}), 6.81 \mathrm{~s}, 1 \mathrm{H}) .7$-Fluoro-2-(3fluorophenyl)- $1 H$-indole (5m): Compound $5 \mathrm{~m}$ was synthesized using above general procedure on $1 \mathrm{gm}$ scale and purified using 5\% ethyl acetate in hexane. Yield 64\% (white solid); ${ }^{1} \mathrm{H}$ NMR ( $\left.\mathrm{CDCl}_{3}, 400 \mathrm{MHz}\right): 8.48$ (bs, 1H), 7.46-7.35 (m, 4H), 7.07-7.01 (m, 2H), 6.92 (dd, $J=8.2,11.4 \mathrm{~Hz}, 1 \mathrm{H}), 6.86(\mathrm{~s}, 1 \mathrm{H})$.

\section{General procedure A, for Michael addition reaction}

In a $5 \mathrm{~mL}$ microwave vial 2-arylindole derivative (1.0 eq.), nitro alkenes (1.3 eq.), $\mathrm{CF}_{3} \mathrm{COONH}_{4}$ (0.2 eq.) were taken in of $25 \%$ aq. $\mathrm{EtOH}(2 \mathrm{~mL})$. The tube was sealed and irradiated under microwave for an appropriate time at $100{ }^{\circ} \mathrm{C}$ under stirring. After completion of reaction, the reaction mixture was diluted with cold water followed by extraction with dichloromethane ( 3 times). Combined dichloromethane layer was evaporated 
under vacuum, the residue was purified by silica gel flash chromatography using GRACETM column to get pure product.

3-(1-(2-Fluorophenyl)-2-nitroethyl)-2-phenyl-1H-indole (6a):

Compound 6a was synthesized using general procedure $\mathbf{A}$ on $400 \mathrm{mg}$ scale and purified using $12 \%$ acetone in hexane. Yield $76 \%$ (white solid), ${ }^{1} \mathrm{H} \mathrm{NMR}\left(\mathrm{CDCl}_{3}, 500 \mathrm{MHz}\right): \delta 8.1$ (bs, $1 \mathrm{H}), 7.52(\mathrm{~d}, J=8.0 \mathrm{~Hz}, 1 \mathrm{H}), 7.4-7.29(\mathrm{~m}, 7 \mathrm{H}), 7.19-7.13(\mathrm{~m}, 2 \mathrm{H}), 7.06(\mathrm{t}, J=8.0 \mathrm{~Hz}$, $1 \mathrm{H}), 7.0-6.95(\mathrm{~m}, 2 \mathrm{H}), 5.49(\mathrm{t}, J=8.5 \mathrm{~Hz}, 1 \mathrm{H}), 5.13-5.05(\mathrm{~m}, 2 \mathrm{H})$; HRMS: m/z calcd for $\mathrm{C}_{22} \mathrm{H}_{17} \mathrm{FN}_{2} \mathrm{O}_{2}[\mathrm{M}+\mathrm{H}]^{+}, 361.1347$; found, 361.1381.

\section{3-(1-(3-Fluorophenyl)-2-nitroethyl)-2-phenyl-1H-indole (6b):}

Compound $\mathbf{6 b}$ was synthesized using general procedure $\mathbf{A}$ on $400 \mathrm{mg}$ scale and purified using $12 \%$ acetone in hexane. Yield $80 \%$ (white solid) ; ${ }^{1} \mathrm{H} \mathrm{NMR}\left(\mathrm{CDCl}_{3}, 500 \mathrm{MHz}\right): \delta 8.13$ (bs, 1H), 7.45-7.37 (m, 6H), 7.35 (d, $J=8.5 \mathrm{~Hz}, 1 \mathrm{H}), 7.24-7.16(\mathrm{~m}, 2 \mathrm{H}), 7.08$ (t, $J=8.0 \mathrm{~Hz}$, $2 \mathrm{H}), 6.97(\mathrm{dt}, J=2.0,10.5 \mathrm{~Hz}, 1 \mathrm{H}) ; 6.88(\mathrm{td}, J=2.5,8.5 \mathrm{~Hz}, 1 \mathrm{H}), 5.26(\mathrm{t}, J=8.0 \mathrm{~Hz}, 1 \mathrm{H})$, $5.13(\mathrm{dd}, J=12.5 \mathrm{~Hz}, J=7 \mathrm{~Hz}, 1 \mathrm{H}), 5.10(\mathrm{qd}, J=7.5,12.5 \mathrm{~Hz}, 2 \mathrm{H}) ;$ HRMS: $\mathrm{m} / \mathrm{z}$ calcd for $\mathrm{C}_{22} \mathrm{H}_{17} \mathrm{FN}_{2} \mathrm{O}_{2}[\mathrm{M}+\mathrm{H}]^{+}, 361.1347$; found, 361.1383 .

\section{3-(1-(4-Fluorophenyl)-2-nitroethyl)-2-phenyl-1H-indole (6c):}

Compound $\mathbf{6 c}$ was synthesized using general procedure $\mathbf{A}$ on $450 \mathrm{mg}$ scale and purified using $12 \%$ acetone in hexane Yield $86 \%$ (off white solid); ${ }^{1} \mathrm{H} \mathrm{NMR}\left(\mathrm{CDCl}_{3}, 500 \mathrm{MHz}\right.$ ): $\delta$ 8.16 (bs, $1 \mathrm{H}), 7.51-7.38(\mathrm{~m}, 7 \mathrm{H}), 7.29(\mathrm{dd}, J=8.5,5.5 \mathrm{~Hz}, 2 \mathrm{H}), 7.22(\mathrm{t}, J=7.0 \mathrm{~Hz}, 1 \mathrm{H})$, $7.13(\mathrm{t}, J=7.0 \mathrm{~Hz}, 1 \mathrm{H}), 6.97(\mathrm{t}, J=9.0 \mathrm{~Hz}, 2 \mathrm{H}), 5.28(\mathrm{t}, J=7.5 \mathrm{~Hz}, 1 \mathrm{H}), 5.13(\mathrm{qd}, J=1.0,7.5$ $\mathrm{Hz}, 2 \mathrm{H})$, HRMS: $\mathrm{m} / \mathrm{z}$ calcd for $\mathrm{C}_{22} \mathrm{H}_{17} \mathrm{FN}_{2} \mathrm{O}_{2}[\mathrm{M}+\mathrm{H}]^{+}, 361.1347$; found, 361.1374 .

\section{3-(2-Nitro-1-phenylethyl)-2-phenyl-1H-indole (6d, GAT211):}

Compound 6d was synthesized using general procedure A on $400 \mathrm{mg}$ scale and purified using $12 \%$ acetone in hexane. Yield $88 \%$ (white solid); ${ }^{1} \mathrm{H} \mathrm{NMR}\left(\mathrm{CDCl}_{3}, 500 \mathrm{MHz}\right) \delta 8.15$ $(\mathrm{s}, 1 \mathrm{H}), 7.52(\mathrm{~d}, J=8.0 \mathrm{~Hz}, 1 \mathrm{H}), 7.49-7.41(\mathrm{~m}, 5 \mathrm{H}), 7.39(\mathrm{~d}, J=8.0 \mathrm{~Hz}, 1 \mathrm{H}), 7.37-7.26(\mathrm{~m}$, $4 \mathrm{H}), 7.26-7.18(\mathrm{~m}, 2 \mathrm{H}), 7.11$ (ddd, J = 1.0, 7.5, 8.5 Hz, 1H), 5.32 (t, $J=8.0 \mathrm{~Hz}, 1 \mathrm{H}), 5.19$ (dd, $J=7.5,12.5 \mathrm{~Hz}, 1 \mathrm{H}), 5.13(\mathrm{dd}, J=8.5,12.5 \mathrm{~Hz}, 1 \mathrm{H})$.

\section{4-Fluoro-3-(2-nitro-1-phenylethyl)-2-phenyl-1H-indole (6e):}

Compound 6e was synthesized using general procedure $\mathbf{A}$ on $420 \mathrm{mg}$ scale and purified using $12 \%$ acetone in hexane. Yield $83 \%$ (white solid); ${ }^{1} \mathrm{H} \mathrm{NMR}\left(\mathrm{CDCl}_{3}, 500 \mathrm{MHz}\right): \delta 8.25$ (bs, $1 \mathrm{H}), 7.47-7.40(\mathrm{~m}, 5 \mathrm{H}), 7.29-7.20(\mathrm{~m}, 5 \mathrm{H}), 7.18(\mathrm{~m}, 2 \mathrm{H}), 6.83(\mathrm{dd}, J=7.5,11.5 \mathrm{~Hz}$, $1 \mathrm{H}), 5.32-5.23(\mathrm{~m}, 2 \mathrm{H}), 5.14(\mathrm{dd}, J=6.0,12.0 \mathrm{~Hz}, 1 \mathrm{H})$; HRMS: $\mathrm{m} / \mathrm{z}$ calcd for $\mathrm{C}_{22} \mathrm{H}_{17} \mathrm{FN}_{2} \mathrm{O}_{2}$ $[\mathrm{M}+\mathrm{H}]^{+}, 361.1347$; found, 361.1357 .

\section{5-Fluoro-3-(2-nitro-1-phenylethyl)-2-phenyl-1H-indole (6f):}

Compound $6 \mathbf{f}$ was synthesized using general procedure $\mathbf{A}$ on $440 \mathrm{mg}$ scale and purified using $12 \%$ acetone in hexane. Yield $74 \%$ (white solid); ${ }^{1} \mathrm{H} \mathrm{NMR}\left(\mathrm{CDCl}_{3}, 500 \mathrm{MHz}\right): \delta 8.08$ (bs, 1H), 7.42-7.36 (m, 5H), 7.25-7.17(m, 6H), 7.06 (dd, $J=2.0,10.0 \mathrm{~Hz}, 1 \mathrm{H}), 6.89$ (td, $J$ 
$=2.5,9.0 \mathrm{~Hz}, 1 \mathrm{H}), 5.21(\mathrm{dd}, J=7.0,9.0 \mathrm{~Hz}, 1 \mathrm{H}), 5.05(\mathrm{qd}, J=6.5,12.5 \mathrm{~Hz}, 2 \mathrm{H})$, HRMS: m/z calcd for $\mathrm{C}_{22} \mathrm{H}_{17} \mathrm{FN}_{2} \mathrm{O}_{2}[\mathrm{M}+\mathrm{H}]^{+}, 361.1347$; found, 361.1312 .

\section{6-Fluoro-3-(2-nitro-1-phenylethyl)-2-phenyl-1H-indole (6g):}

Compound $\mathbf{6 g}$ was synthesized using general procedure $\mathbf{A}$ on $400 \mathrm{mg}$ scale and purified using $12 \%$ acetone in hexane. Yield $76 \%$ (white solid); ${ }^{1} \mathrm{H} \mathrm{NMR}\left(\mathrm{CDCl}_{3}, 500 \mathrm{MHz}\right): \delta 8.15$ (bs, 1H), 7.47-7.41(m, 5H), 7.39 (dd, $J=5.0,8.5 \mathrm{~Hz}, 1 \mathrm{H}), 7.31-7.24(\mathrm{~m}, 5 \mathrm{H}), 7.07$ (dd, $J$ $=2.0,9.5 \mathrm{~Hz}, 1 \mathrm{H}), 6.87(\mathrm{td}, J=2.0,9.0 \mathrm{~Hz}, 1 \mathrm{H}), 5.31(\mathrm{dd}, J=7.5,9.0 \mathrm{~Hz}, 1 \mathrm{H}), 5.13(\mathrm{qd}, J=$ 7.0, $13.0 \mathrm{~Hz}, 2 \mathrm{H}), \mathrm{HRMS}: \mathrm{m} / \mathrm{z}$ calcd for $\mathrm{C}_{22} \mathrm{H}_{17} \mathrm{FN}_{2} \mathrm{O}_{2}[\mathrm{M}+\mathrm{H}]^{+}, 361.1347$; found, 361.1346 .

\section{7-Fluoro-3-(2-nitro-1-phenylethyl)-2-phenyl-1H-indole (6h):}

Compound $\mathbf{6 h}$ was synthesized using general procedure A on $400 \mathrm{mg}$ scale and purified using $12 \%$ acetone in hexane. Yield $73 \%$ (white solid); ${ }^{1} \mathrm{H} \mathrm{NMR}\left(\mathrm{CDCl}_{3}, 500 \mathrm{MHz}\right): \delta 8.33$ (bs, 1H), 7.49-7.44 (m, 5H), 7.32-7.23 (m, , 6H), 7.02 (td, $J=4.5,7.5 \mathrm{~Hz}, 1 \mathrm{H}), 6.93$ (dd, $J$ $=8.0,1.5 \mathrm{~Hz}, 1 \mathrm{H}), 5.30(\mathrm{dd}, J=7.5,8.5 \mathrm{~Hz}, 1 \mathrm{H}), 5.14(\mathrm{qd}, J=7.0,12.0 \mathrm{~Hz}, 2 \mathrm{H})$; HRMS: $\mathrm{m} / \mathrm{z}$ calcd for $\mathrm{C}_{22} \mathrm{H}_{17} \mathrm{FN}_{2} \mathrm{O}_{2}[\mathrm{M}+\mathrm{H}]^{+}, 361.1347$; found, 361.1370 .

\section{2-(2-Fluorophenyl)-3-(2-nitro-1-phenylethyl)-1H-indole (6i):}

Compound 6i was synthesized using general procedure A on $400 \mathrm{mg}$ scale and purified using $12 \%$ acetone in hexane. Yield $71 \%$ (white solid); ${ }^{1} \mathrm{H} \mathrm{NMR}\left(\mathrm{CDCl}_{3}, 500 \mathrm{MHz}\right): \delta 8.23$ (bs, $1 \mathrm{H}) ; 7.46(\mathrm{~d}, J=8.0 \mathrm{~Hz}, 1 \mathrm{H}) ; 7.43-7.38(\mathrm{~m}, 1 \mathrm{H}) ; 7.37-7.33(\mathrm{~m}, 2 \mathrm{H}) ; 7.30-7.24(\mathrm{~m}, 4 \mathrm{H})$; 7.23-7.17(m, 4H); 7.08(t, $J=7.0 \mathrm{~Hz}, 1 \mathrm{H}) ; 5.24-5.16(\mathrm{~m}, 2 \mathrm{H}), 5.09-5.04(\mathrm{~m}, 1 \mathrm{H})$; HRMS: $\mathrm{m} / \mathrm{z}$ calcd for $\mathrm{C}_{22} \mathrm{H}_{17} \mathrm{FN}_{2} \mathrm{O}_{2}[\mathrm{M}+\mathrm{H}]^{+}, 361.1347$; found, 361.1353 .

\section{2-(3-Fluorophenyl)-3-(2-nitro-1-phenylethyl)-1H-indole (6j):}

Compound $\mathbf{6 j}$ was synthesized using general procedure $\mathbf{A}$ on $450 \mathrm{mg}$ scale and purified using $12 \%$ acetone in hexane. Yield $81 \%$ (white solid); ${ }^{1} \mathrm{H} \mathrm{NMR}\left(\mathrm{CDCl}_{3}, 500 \mathrm{MHz}\right): \delta 8.16$ (bs, 1H), 7.54 (d, $J=8.0 \mathrm{~Hz}, 1 \mathrm{H})$; 7.44-7.38 (m, 2H), 7.35-7.28 (m, 4H), 7.26-7.20 (m, $3 \mathrm{H}), 7.16-7.10(\mathrm{~m}, 3 \mathrm{H}), 5.31(\mathrm{t}, J=7.5 \mathrm{~Hz}, 1 \mathrm{H}), 5.20-5.13(\mathrm{~m}, 2 \mathrm{H})$; HRMS: $\mathrm{m} / \mathrm{z}$ calcd for $\mathrm{C}_{22} \mathrm{H}_{17} \mathrm{FN}_{2} \mathrm{O}_{2}[\mathrm{M}+\mathrm{H}]^{+}$, 361.1347; found, 361.1359.

\section{2-(4-Fluorophenyl)-3-(2-nitro-1-phenylethyl)-1H-indole (6k):}

Compound 6k was synthesized using general procedure A on $500 \mathrm{mg}$ scale and purified using $12 \%$ acetone in hexane. Yield $72 \%$ (white solid); ${ }^{1} \mathrm{H}$ NMR (DMSO $d_{6}, 500 \mathrm{MHz}$ ): $\delta$ 11.47 (bs, 1H), $7.64(\mathrm{~d}, J=8.0 \mathrm{~Hz}, 1 \mathrm{H}), 7.56(\mathrm{td}, J=5.5,9.0 \mathrm{~Hz}, 2 \mathrm{H}), 7.43-7.37$ (m, 3H), $7.33-7.27(\mathrm{~m}, 4 \mathrm{H}), 7.21(\mathrm{tt}, J=1.5,7.0 \mathrm{~Hz}, 1 \mathrm{H}), 7.11(\mathrm{dd}, J=1.0,7.5 \mathrm{~Hz}, 1 \mathrm{H}), 6.98(\mathrm{t}, J=$ $1.0,7.5 \mathrm{~Hz}, 1 \mathrm{H}), 5.56(\mathrm{dd}, J=7.0,13.0 \mathrm{~Hz}, 1 \mathrm{H}), 5.44(\mathrm{dd}, J=9.5,13.0 \mathrm{~Hz}, 1 \mathrm{H}), 5.15(\mathrm{t}, J=$ $8.0 \mathrm{~Hz}, 1 \mathrm{H}) ; \mathrm{HRMS}$ : $\mathrm{m} / \mathrm{z}$ calcd for $\mathrm{C}_{22} \mathrm{H}_{17} \mathrm{FN}_{2} \mathrm{O}_{2}[\mathrm{M}+\mathrm{H}]^{+}$, 361.1347; found, 361.1357 .

\section{6-Fluoro-3-(1-(2-fluorophenyl)-2-nitroethyl)-2-phenyl-1H-indole (6I):}

Compound $\mathbf{6 1}$ was synthesized using general procedure A on $410 \mathrm{mg}$ scale and purified using $12 \%$ acetone in hexane. Yield $70 \%$ (white solid); ${ }^{1} \mathrm{H} \mathrm{NMR}\left(\mathrm{CDCl}_{3}, 500 \mathrm{MHz}\right): \delta 8.17$ (bs, 1H), 7.54-7.40 (m, 6H), 7.32(t, $J=8.0 \mathrm{~Hz}, 1 \mathrm{H}), 7.28-7.22(\mathrm{~m}, 1 \mathrm{H}), 7.09-7.04(\mathrm{~m}, 3 \mathrm{H})$, 
$6.90(\mathrm{td}, J=2.0,8.5 \mathrm{~Hz}, 1 \mathrm{H}), 5.53(\mathrm{t}, J=8.0 \mathrm{~Hz}, 1 \mathrm{H}), 5.13(\mathrm{~d}, J=8.0 \mathrm{~Hz}, 2 \mathrm{H}) ; \mathrm{HRMS}: \mathrm{m} / \mathrm{z}$ calcd for $\mathrm{C}_{22} \mathrm{H}_{16} \mathrm{~F}_{2} \mathrm{~N}_{2} \mathrm{O}_{2}[\mathrm{M}+\mathrm{H}]^{+}, 379.1253$; found, 379.1250 .

7-Fluoro-3-(1-(2-fluorophenyl)-2-nitroethyl)-2-phenyl-1H-indole (6m):

Compound 6m was synthesized using general procedure $\mathbf{A}$ on $400 \mathrm{mg}$ scale and purified using $12 \%$ acetone in hexane. Yield $85 \%$ (white solid); ${ }^{1} \mathrm{H} \mathrm{NMR}\left(\mathrm{CDCl}_{3}\right): \delta 8.35(\mathrm{bs}, 1 \mathrm{H})$, 7.51-7.43 (m, 5H), 7.35-7.32(m, 2H), 7.28-7.23(m, 1H), 7.08-7.04(m, 3H), 6.93(dd, $J=3.0$, $8.0 \mathrm{~Hz}, 1 \mathrm{H}), 5.53(\mathrm{t}, J=8.5 \mathrm{~Hz}, 1 \mathrm{H}), 5.18-5.10(\mathrm{~m}, 2 \mathrm{H})$; HRMS: $\mathrm{m} / \mathrm{z}$ calcd for $\mathrm{C}_{22} \mathrm{H}_{16} \mathrm{~F}_{2} \mathrm{~N}_{2} \mathrm{O}_{2}[\mathrm{M}+\mathrm{H}]^{+}$, 379.1253; found, 379.1248 .

7-Fluoro-3-(1-(4-fluorophenyl)-2-nitroethyl)-2-phenyl-1H-indole (6n):

Compound 6e was synthesized using general procedure $\mathbf{A}$ on $600 \mathrm{mg}$ scale and purified using $15 \%$ ethyl acetate in hexane. Yield $65 \%$ (white semi-solid); ${ }^{1} \mathrm{H} \mathrm{NMR}\left(\mathrm{CDCl}_{3}, 500\right.$ MHz): $\delta 8.17$ (bs, 1H), 7.48-7.43 (m, 3 H), 7.41-7.35 (m, 3H), 7.28-7.25 (m, 2H), 7.06 (dd, $J=3.0,9.0 \mathrm{~Hz}, 1 \mathrm{H}), 7.00-6.97(\mathrm{~m}, 2 \mathrm{H}), 6.88(\mathrm{dt}, J=2.6,9.0 \mathrm{~Hz}, 1 \mathrm{H}), 5.27(\mathrm{t}, J=8.0 \mathrm{~Hz}, 1 \mathrm{H})$, $5.11(\mathrm{dd}, J=7.5,12.7 \mathrm{~Hz}, 1 \mathrm{H}), 5.07$ (dd, $J=8.5,12.4 \mathrm{~Hz}, 1 \mathrm{H})$; HRMS: $\mathrm{m} / \mathrm{z}$ calcd for $\mathrm{C}_{22} \mathrm{H}_{16} \mathrm{~F}_{2} \mathrm{~N}_{2} \mathrm{O}_{2}[\mathrm{M}+\mathrm{H}]^{+}$, 379.1253; found, 379.1226.

\section{6-Fluoro-3-(1-(4-fluorophenyl)-2-nitroethyl)-2-phenyl-1H-indole (60):}

Compound 60 was synthesized using general procedure $\mathbf{A}$ on $600 \mathrm{mg}$ scale and purified using $15 \%$ ethyl acetate in hexane. Yield $51 \%$ (off white solid); ${ }^{1} \mathrm{H}$ NMR $\left(\mathrm{CDCl}_{3}, 500\right.$ MHz): $\delta 8.34$ (bs, 1H), 7.50-7.43 (m, 5H), 7.28-7.24 (m, 3H), 7.05-6.91 (m, 4H), $5.26(\mathrm{t}$, $J=7.3 \mathrm{~Hz}, 1 \mathrm{H}), 5.15-5.06(\mathrm{~m}, 2 \mathrm{H})$; HRMS: $\mathrm{m} / \mathrm{z}$ calcd for $\mathrm{C}_{22} \mathrm{H}_{16} \mathrm{~F}_{2} \mathrm{~N}_{2} \mathrm{O}_{2}[\mathrm{M}+\mathrm{H}]^{+}$, 379.1253; found, 379.1251 .

\section{6-Fluoro-2-(3-fluorophenyl)-3-(1-(4-fluorophenyl)-2-nitroethyl)-1H-indole (6p):}

Compound 6p was synthesized using general procedure A under reflux condition on $650 \mathrm{mg}$ scale and purified using 15\% ethyl acetate in hexane. Yield 63\% (white solid); ${ }^{1} \mathrm{H}$ NMR $\left(\mathrm{CDCl}_{3}, 500 \mathrm{MHz}\right.$ ): $\delta 8.18$ (bs, 1H), 7.46-7.38 (m, 2H), 7.28-7.25 (m, 2H), 7.19 (dd, J=1.0, $7.8 \mathrm{~Hz}, 1 \mathrm{H}), 7.15-7.11(\mathrm{~m}, 2 \mathrm{H}), 7.07(\mathrm{dd}, J=2.4,6.8 \mathrm{~Hz}, 1 \mathrm{H}), 7.02-6.99(\mathrm{~m}, 2 \mathrm{H}), 6.90(\mathrm{dt}$, $J=2.6,8.7 \mathrm{~Hz}, 1 \mathrm{H}), 5.26(\mathrm{t}, J=9.6 \mathrm{~Hz}, 1 \mathrm{H}), 5.15-5.07(\mathrm{~m}, 2 \mathrm{H}) ; \mathrm{HRMS}: \mathrm{m} / \mathrm{z}$ calcd for $\mathrm{C}_{22} \mathrm{H}_{15} \mathrm{~F}_{3} \mathrm{~N}_{2} \mathrm{O}_{2}[\mathrm{M}+\mathrm{H}]^{+}$, 397.1158; found, 397.1183.

\section{7-Fluoro-2-(3-fluorophenyl)-3-(1-(4-fluorophenyl)-2-nitroethyl)-1H-indole (6q):}

6q was synthesized using general procedure $\mathbf{A}$ under reflux condition on $450 \mathrm{mg}$ scale and purified using $15 \%$ ethyl acetate in hexane. Yield $73 \%$ (white solid); ${ }^{1} \mathrm{H}$ NMR $\left(\mathrm{CDCl}_{3}, 500\right.$ MHz): $\delta 8.35$ (bs, 1H), 7.48-7.44 (m, 1H), 7.29-7.23 (m, 4H), 7.19-7.15 (m, 2H), 7.08$7.04(\mathrm{~m}, 1 \mathrm{H}), 7.02-6.94(\mathrm{~m}, 3 \mathrm{H}), 5.26(\mathrm{t}, J=8.6 \mathrm{~Hz}, 1 \mathrm{H}), 5.13(\mathrm{bs}, 1 \mathrm{H}), 5.12(\mathrm{bs}, 1 \mathrm{H})$; HRMS: $\mathrm{m} / \mathrm{z}$ calcd for $\mathrm{C}_{22} \mathrm{H}_{15} \mathrm{~F}_{3} \mathrm{~N}_{2} \mathrm{O}_{2}[\mathrm{M}+\mathrm{H}]^{+}, 397.1158$; found, 397.1182 .

\section{6-Fluoro-2-(3-fluorophenyl)-3-(1-(2-fluorophenyl)-2-nitroethyl)-1H-indole (6r):}

Compound $\mathbf{6 r}$ was synthesized using general procedure $\mathbf{A}$ under reflux condition on $300 \mathrm{mg}$ scale and purified using $15 \%$ ethyl acetate in hexane. Yield 80\%; (white solid) ${ }^{1} \mathrm{H}$ NMR $\left(\mathrm{CDCl}_{3}, 400 \mathrm{MHz}\right): 8.17$ (bs, 1H), 7.49 (dd, $\left.J=5.3,8.8 \mathrm{~Hz}, 1 \mathrm{H}\right), 7.47-7.41(\mathrm{~m}, 1 \mathrm{H}), 7.33-$ 
7.20 (m, 3H), 7.15-7.05 (m,5H), $6.91(\mathrm{dt}, J=1.9,8.7 \mathrm{~Hz}, 1 \mathrm{H}),$,5.52 (t, $J=8.1 \mathrm{~Hz}, 1 \mathrm{H}), 5.15$ (s, $1 \mathrm{H}), 5.13(\mathrm{~s}, 1 \mathrm{H}) ;{ }^{13} \mathrm{C}$ NMR $\left(100 \mathrm{MHz}, \mathrm{DMSO}-d_{6}\right) \delta 162.63(\mathrm{~d}, J=227.3 \mathrm{~Hz}), 160.18$ (d, $J=229.1 \mathrm{~Hz}), 159.41(\mathrm{~d}, J=236.6 \mathrm{~Hz}) 136.60(\mathrm{~d}, J=12.6 \mathrm{~Hz}), 136.18(\mathrm{~d}, J=2.8 \mathrm{~Hz})$, $134.75(\mathrm{~d}, J=8.4 \mathrm{~Hz}), 131.24(\mathrm{~d}, J=8.5 \mathrm{~Hz}), 129.58(\mathrm{~d}, J=8.4 \mathrm{~Hz}), 128.73(\mathrm{~d}, J=3.6 \mathrm{~Hz})$, 126.99 (d, $J=13.8 \mathrm{~Hz}), 125.21(\mathrm{~d}, J=2.7 \mathrm{~Hz}), 124.93(\mathrm{~d}, J=3.4 \mathrm{~Hz}), 123.45,121.51$ (d, $J=$ $10.0 \mathrm{~Hz}), 116.11(\mathrm{~d}, J=21.8 \mathrm{~Hz}), 115.76(\mathrm{~d}, J=22.3 \mathrm{~Hz}), 115.48(\mathrm{~d}, J=20.9 \mathrm{~Hz}), 108.52$ (d, $J=9.2 \mathrm{~Hz}), 108.33,98.01$ (d, $J=25.3 \mathrm{~Hz}), 77.02,34.39$ (d, $J=2.8 \mathrm{~Hz}) ; \mathrm{HRMS} \mathrm{:} \mathrm{m/z}$ calcd for $\mathrm{C}_{22} \mathrm{H}_{15} \mathrm{~F}_{3} \mathrm{~N}_{2} \mathrm{O}_{2}[\mathrm{M}+\mathrm{H}]^{+}$, 397.1158; found, 397.1177.

\section{7-Fluoro-2-(3-fluorophenyl)-3-(1-(2-fluorophenyl)-2-nitroethyl)-1H-indole (6s):}

Compound 6s was synthesized using general procedure $\mathbf{A}$ under reflux condition on $300 \mathrm{mg}$ scale and purified using 15\% ethyl acetate in hexane. Yield 83\% (white solid); ${ }^{1} \mathrm{H}$ NMR $\left(\mathrm{CDCl}_{3}, 400 \mathrm{MHz}\right): 8.35(\mathrm{~s}, 1 \mathrm{H}), 7.45(\mathrm{q}, J=8.22 \mathrm{~Hz}, 1 \mathrm{H}), 7.37-7.33(\mathrm{~m}, 2 \mathrm{H}), 7.31-7.24(\mathrm{~m}$, 2H), 7.18-7.14 (m, 2H), 7.187.14 (m, 2H), 7.10-7.04 (m, 3H), 6.98-6.94 (m, 1H), $5.52(\mathrm{t}$, $J=7.6 \mathrm{~Hz}, 1 \mathrm{H}), 5.21-5.10(\mathrm{~m}, 2 \mathrm{H}) ; 13 \mathrm{C}$ NMR $(100 \mathrm{MHz}, \mathrm{DMSO}-\mathrm{d} 6) \delta 162.57$ (d, J = 217.3 $\mathrm{Hz}), 160.13(\mathrm{~d}, \mathrm{~J}=219.0 \mathrm{~Hz}), 149.63(\mathrm{~d}, \mathrm{~J}=243.8 \mathrm{~Hz}), 136.98,134.34$ (d, J = 8.4 Hz), 131.09 (d, J = 8.6 Hz), $130.36(\mathrm{~d}, \mathrm{~J}=5.5 \mathrm{~Hz}), 129.59$ (d, J = 8.6 Hz), 128.72, $126.86(\mathrm{~d}, \mathrm{~J}=$ $13.8 \mathrm{~Hz}), 125.70,124.91(\mathrm{~d}, \mathrm{~J}=3.5 \mathrm{~Hz}), 124.56(\mathrm{~d}, \mathrm{~J}=13.6 \mathrm{~Hz}), 120.30(\mathrm{~d}, \mathrm{~J}=6.1 \mathrm{~Hz})$, 116.39 (d, J = 7.6 Hz), 116.29 (d, J = 17.7 Hz), 116.10 (d, J = 21.8 Hz) 115.75 (d, J = 20.9 $\mathrm{Hz}$ ), 109.44, 107.13 (d, J = 15.9 Hz), 76.94, 34.39; HRMS: $\mathrm{m} / \mathrm{z}$ calcd for $\mathrm{C}_{22} \mathrm{H}_{15} \mathrm{~F}_{3} \mathrm{~N}_{2} \mathrm{O}_{2}$ [M $+\mathrm{H}]^{+}, 397.1158$; found, 397.1160 .

\section{(E)-3-fluoro-2-(2-nitrovinyl)pyridine (8d):}

To a solution of 3-fluoropyridine-2-carboxaldehyde (12 mmol, 1 eq.) in ${ }^{t} \mathrm{BuOH}: T H F$ (1:1; $14.4 \mathrm{~mL}$ ) was added nitromethane $(19.2 \mathrm{mmol}, 1.6$ eq.); the reaction mixture was stirred at 0 ${ }^{\circ} \mathrm{C}$ then potassium tert-butoxide $(0.72 \mathrm{mmol}, 6 \mathrm{~mol} \%)$ was added directly added. Following two hours of stirring at $0^{\circ} \mathrm{C}$, the reaction mixture was concentrated under reduced pressure to remove ${ }^{t} \mathrm{BuOH}$, diluted with diethyl ether and ethyl acetate, then washed with water, saturated $\mathrm{NaHCO}_{3}$ solution, and brine. The aqueous phase was extracted $3 \mathrm{X}$ with diethyl ether; the combined organic extracts were dried with $\mathrm{Na}_{2} \mathrm{SO}_{4}$ then concentrated under reduced pressure. The nitroalcohol intermediate obtained from workup was used for the next step without any further purification.

To a $100 \mathrm{~mL}$ round bottom flask containing the crude nitroalcohol ( $8.06 \mathrm{mmol}, 1 \mathrm{eq}$.) and 4DMAP (0.4 mmol, $5 \mathrm{~mol} \%)$ was added anhydrous DCM $(40 \mathrm{~mL})$; the mixture was stirred under argon at room temp. Acetic anhydride $(8.87 \mathrm{mmol}, 1.1 \mathrm{eq}$.) was added dropwise to the stirred mixture; the resulting reaction mixture continued stirring under argon at room temp. Following two hours of room temp stirring, the reaction mixture was quenched with saturated $\mathrm{NaHCO}_{3}$ solution then washed with water and brine. The aqueous phase was extracted $3 \mathrm{X}$ with DCM; combined organic extracts were dried with $\mathrm{Na}_{2} \mathrm{SO}_{4}$, then concentrated under reduced pressure. The crude organic resin was purified by silica gel flash chromatography using ethyl acetate/hexanes eluent to obtain the desired nitrovinyl compound as a yellow solid, yield $=67 \% .{ }^{1} \mathrm{H}$ NMR $\left(500 \mathrm{MHz}, \mathrm{CDCl}_{3}\right) \delta: 8.51(\mathrm{~d}, J=4.2$ $\mathrm{Hz}, 1 \mathrm{H}), 8.18(\mathrm{~d}, J=13.5 \mathrm{~Hz}, 1 \mathrm{H}), 8.04(\mathrm{~d}, J=13.5 \mathrm{~Hz}, 1 \mathrm{H}), 7.53(\mathrm{t}, J=9.1 \mathrm{~Hz}, 1 \mathrm{H}), 7.45$ (dt, $J=8.4,4.3 \mathrm{~Hz}, 1 \mathrm{H})$. 


\section{3-(2-Nitro-1-(pyridin-2-yl)ethyl)-2-phenyl-1H-indole (9a):}

Compound 9a was synthesized using reported literature protocol ${ }^{41}$ on $400 \mathrm{mg}$ scale and purified using 30-70\% acetone in hexane. Yield 58\% (off white solid); ${ }^{1} \mathrm{H} \mathrm{NMR}\left(\mathrm{CDCl}_{3}\right.$, $500 \mathrm{MHz}): 8.16(\mathrm{bs}, 1 \mathrm{H}), 7.53(\mathrm{~d}, J=8.0 \mathrm{~Hz}, 1 \mathrm{H}), 7.49-7 . .43(\mathrm{~m}, 5 \mathrm{H}), 7.40(\mathrm{~d}, J=7.7 \mathrm{~Hz}$, $1 \mathrm{H}), 7.34$ (d, $J=7.6 \mathrm{~Hz}, 2 \mathrm{H}), 7.30(\mathrm{t}, J=7.2 \mathrm{~Hz}, 2 \mathrm{H}), 7.22(\mathrm{t}, J=8.4 \mathrm{~Hz}, 1 \mathrm{H}), 7.12(\mathrm{t}, J=8.1 \mathrm{~Hz}$, $1 \mathrm{H}), 5.33(\mathrm{t}, J=8.2 \mathrm{~Hz}, 1 \mathrm{H}), 5.19(\mathrm{dd}, J=7.4,12.5 \mathrm{~Hz}, 1 \mathrm{H}), 5.13$ (dd, $J=8.4,12.5 \mathrm{~Hz}, 1 \mathrm{H})$; HRMS: $\mathrm{m} / \mathrm{z}$ calcd for $\mathrm{C}_{21} \mathrm{H}_{17} \mathrm{~N}_{3} \mathrm{O}_{2}[\mathrm{M}+\mathrm{H}]^{+}, 344.1394$; found, 344.1400 .

\section{3-(2-Nitro-1-(pyridin-3-yl)ethyl)-2-phenyl-1H-indole (9b):}

9b was synthesized using reported literature protocol ${ }^{41}$ on $400 \mathrm{mg}$ scale and purified using 30-70\% acetone in hexane. Yield 40\% (off white solid); ${ }^{1} \mathrm{H}$ NMR (DMSO $d_{6}, 500 \mathrm{MHz}$ ): $11.52(\mathrm{~s}, 1 \mathrm{H}), 8.49(\mathrm{~d}, J=2.2 \mathrm{~Hz}, 1 \mathrm{H}), 8.42(\mathrm{dd}, J=1.6,4.4 \mathrm{~Hz}, 1 \mathrm{H}), 7.77-7.75(\mathrm{~m}, 1 \mathrm{H}), 7.69$ (d, $J=7.7 \mathrm{~Hz}, 1 \mathrm{H}), 7.58-7.53(\mathrm{~m}, 4 \mathrm{H}), 7.50-7.47(\mathrm{~m}, 1 \mathrm{H}), 7.13(\mathrm{t}, J=7.9 \mathrm{~Hz}, 1 \mathrm{H}), 7.00(\mathrm{t}$, $J=7.5 \mathrm{~Hz}, 1 \mathrm{H}), 5.65(\mathrm{dd}, J=7.6,13.8 \mathrm{~Hz}, 1 \mathrm{H}), 5.51(\mathrm{dd}, J=9.0,13.2 \mathrm{~Hz}, 1 \mathrm{H}), 5.24(\mathrm{t}, J=7.7$ $\mathrm{Hz}, 1 \mathrm{H}) ; \mathrm{HRMS}: \mathrm{m} / \mathrm{z}$ calcd for $\mathrm{C}_{21} \mathrm{H}_{17} \mathrm{~N}_{3} \mathrm{O}_{2}[\mathrm{M}+\mathrm{H}]^{+}, 344.1394$; found, 344.1413 .

\section{3-(2-Nitro-1-(pyridin-4-yl)ethyl)-2-phenyl-1H-indole (9c):}

Compound $9 \mathrm{c}$ was synthesized using reported literature protocol ${ }^{41}$ on $450 \mathrm{mg}$ scale and purified using 30-70\% acetone in hexane. Yield 27\% (off white solid); ${ }^{1} \mathrm{H} \mathrm{NMR}\left(\mathrm{CDCl}_{3}\right.$, $500 \mathrm{MHz}$ ): 8.53-8.52 (bs, 1H), 8.31 (s, 1H), 7.517.46 (m, 3H), 7.45-7.42 (m, 4H), 7.25$7.22(\mathrm{~m}, 3 \mathrm{H}), 7.15-7.11(\mathrm{~m}, 1 \mathrm{H}), 5.31(\mathrm{t}, J=7.9 \mathrm{~Hz}, 1 \mathrm{H}), 5.23(\mathrm{dd}, J=7.8,12.9 \mathrm{~Hz}, 1 \mathrm{H}), 5.09$ (dd, $J=7.8,12.6 \mathrm{~Hz}, 1 \mathrm{H}$ ); HRMS: $\mathrm{m} / \mathrm{z}$ calcd for $\mathrm{C}_{21} \mathrm{H}_{17} \mathrm{~N}_{3} \mathrm{O}_{2}[\mathrm{M}+\mathrm{H}]^{+}, 344.1394$; found, 344.1378 .

\section{3-(2-Nitro-1-phenylethyl)-2-(pyridin-4-yl)-1H-indole (9e):}

Compound 9e was synthesized using reported literature protocol ${ }^{41}$ using $\mathrm{Et}_{4} \mathrm{NBr}$ on $420 \mathrm{mg}$ scale and purified using 30-70\% acetone in hexane.; Yield 54\% (off white solid); ${ }^{1} \mathrm{H}$ NMR $\left(\mathrm{CDCl}_{3}, 500 \mathrm{MHz}\right): 9.26$ (bs, 1H), 8.60 (d, $\left.J=5.8 \mathrm{~Hz}, 2 \mathrm{H}\right), 7.56$ (d, $\left.J=8.0 \mathrm{~Hz}, 1 \mathrm{H}\right), 7.41$ (d, $J=8.4 \mathrm{~Hz}, 1 \mathrm{H}), 7.35-7.30(\mathrm{~m}, 6 \mathrm{H}), 7.28-7.23(\mathrm{~m}, 2 \mathrm{H}), 7.13(\mathrm{t}, J=7.9 \mathrm{~Hz}, 1 \mathrm{H}), 5.36(\mathrm{dd}$, $J=7.2,8.8 \mathrm{~Hz}, 1 \mathrm{H}), 5.22(\mathrm{dd}, J=8.7,12.8 \mathrm{~Hz}, 1 \mathrm{H}), 5.17(\mathrm{dd}, J=6.9,12.2 \mathrm{~Hz}, 1 \mathrm{H})$; HRMS: $\mathrm{m} / \mathrm{z}$ calcd for $\mathrm{C}_{21} \mathrm{H}_{17} \mathrm{~N}_{3} \mathrm{O}_{2}[\mathrm{M}+\mathrm{H}]^{+}, 344.1394$; found, 344.1374 .

\section{3-(2-Nitro-1-phenylethyl)-2-(pyridin-3-yl)-1H-indole (9d):}

Compound 9d was synthesized using reported literature protocol ${ }^{41}$ using $\mathrm{Et}_{4} \mathrm{NBr}$ on $400 \mathrm{mg}$ scale and purifies using 30-70\% acetone in hexane. Yield 68\% (off white solid); ${ }^{1} \mathrm{H}$ NMR $\left(\mathrm{CDCl}_{3}, 500 \mathrm{MHz}\right): 8.69(\mathrm{~d}, J=2.0 \mathrm{~Hz}, 1 \mathrm{H}), 8.65-8.64(\mathrm{~m}, 2 \mathrm{H}), 7.74(\mathrm{dt}, J=7.8,1.82 \mathrm{~Hz}$, $1 \mathrm{H}), 8.65-8.64(\mathrm{~m}, 2 \mathrm{H}), 7.74(\mathrm{dt}, J=7.8,1.8 \mathrm{~Hz}, 1 \mathrm{H}), 7.57(\mathrm{~d}, J=8.2 \mathrm{~Hz}, 1 \mathrm{H}), 7.42(\mathrm{~d}, J=8.1$ $\mathrm{Hz}, 1 \mathrm{H}), 7.37(\mathrm{dd}, J=4.9,8.1 \mathrm{~Hz}, 1 \mathrm{H}), 7.34-7.27(\mathrm{~m}, 4 \mathrm{H}), 7.26-7.21(\mathrm{~m}, 2 \mathrm{H}), 7.15(\mathrm{t}, J=7.5$ $\mathrm{Hz}, 1 \mathrm{H}), 5.25-5.22(\mathrm{~m}, 1 \mathrm{H}), 5.20-5.14(\mathrm{~m}, 2 \mathrm{H}) ; \mathrm{HRMS}: \mathrm{m} / \mathrm{z}$ calcd for $\mathrm{C}_{21} \mathrm{H}_{17} \mathrm{~N}_{3} \mathrm{O}_{2}[\mathrm{M}+$ $\mathrm{H}]^{+}$, 344.1394; found, 344.1395 .

\section{General Procedure B, for Michael addition reaction:}

In an oven dried two neck round bottom flask aza idole (1 eq.) was taken under argon atmosphere, dissolved with anhydrous THF and cooled to $-78{ }^{\circ} \mathrm{C}$. ${ }^{\mathrm{n}} \mathrm{BuLi}$ (5 eq.) was added 
slowly to the solution and after complete addition the reaction mixture was stirred at RT for 3 hours (colorless solution turned into brown color solution). Again, the reaction mixture was cooled to $-78{ }^{\circ} \mathrm{C}$ and then a solution of nitrostyrene (5eq.) in anhydrous THF was added dropwise. The reaction mixture temp was slowly raised to RT and stirred for overnight. The reaction mixture was cooled and quenched with sat. $\mathrm{NH}_{4} \mathrm{Cl}$ solution. The aqueous phase was extracted with EtOAc. The combined organic layer was washed with brine $(7 \mathrm{~mL})$ and dried over anhydrous $\mathrm{Na}_{2} \mathrm{SO}_{4}$, filtered, and concentrated under reduced pressure. Purification of the residue on a silica gel column using $\mathrm{MeOH}$ :DCM as a solvent system furnished the Michael adduct.

\section{3-(2-Nitro-1-phenylethyl)-2-phenyl-1H-pyrrolo[3,2-b]pyridine (9f):}

Compound $9 f$ was synthesized using general procedure B on $1.6 \mathrm{gm}$ scale and purified using $10 \% \mathrm{CH}_{3} \mathrm{OH}$ in DCM. Yield: $52 \%$ (yellowish white solid); ${ }^{1} \mathrm{H} \mathrm{NMR}\left(\mathrm{CDCl}_{3}, 400 \mathrm{MHz}\right): \delta$ $8.50(\mathrm{~d}, J=4.4 \mathrm{~Hz}, 1 \mathrm{H}), 8.24(\mathrm{bs}, 1 \mathrm{H}), 7.66(\mathrm{~d}, J=7.8 \mathrm{~Hz}, 1 \mathrm{H}), 7.54-7.48(\mathrm{~m}, 3 \mathrm{H}), 7.41-7.37$ (m, 2H), 7.28-7.29 (m 2H), 7.187.14 (m, 1H), 7.09 (d, J=7.2 Hz, 2H), $6.70(\mathrm{~s}, 1 \mathrm{H}), 5.30(\mathrm{dd}$, $J=6.5,10.1 \mathrm{~Hz}, 1 \mathrm{H}), 5.13(\mathrm{dd}, J=10.5,12.8 \mathrm{~Hz}, 1 \mathrm{H}), 4.89(\mathrm{dd}, J=6.0,13.0 \mathrm{~Hz}, 1 \mathrm{H})$; HRMS: $\mathrm{m} / \mathrm{z}$ calcd for $\mathrm{C}_{21} \mathrm{H}_{17} \mathrm{~N}_{3} \mathrm{O}_{2}[\mathrm{M}+\mathrm{H}]^{+}$, 344.1394; found, 344.1419.

\section{3-(2-Nitro-1-phenylethyl)-2-phenyl-1H-pyrrolo[3,2-c]pyridine (9g):}

Compound $9 \mathrm{~g}$ was synthesized using general procedure $\mathrm{B}$ on $1.2 \mathrm{gm}$ scale and purified using $10 \% \mathrm{CH}_{3} \mathrm{OH}$ in DCM. Yield: $43 \%$ (brown solid); ${ }^{1} \mathrm{H}$ NMR $(\mathrm{CDCl} 3,500 \mathrm{MHz})$ : $\delta$ $8.89(\mathrm{~s}, 1 \mathrm{H}), 8.60(\mathrm{bs}, 1 \mathrm{H}), 8.35(\mathrm{~d}, J=5.7 \mathrm{~Hz}, 1 \mathrm{H}), 7.53-7.46(\mathrm{~m}, 5 \mathrm{H}), 7.33-7.31(\mathrm{~m}, 5 \mathrm{H})$, 7.28-7.27 (m, 1H), 5.32 (dd, J=7.3, 8.7 Hz, 1H), 5.18 (bs, $1 \mathrm{H}), 5.16$ (d, $J=2.3 \mathrm{~Hz}, 1 \mathrm{H}$ ); HRMS: $\mathrm{m} / \mathrm{z}$ calcd for $\mathrm{C}_{21} \mathrm{H}_{17} \mathrm{~N}_{3} \mathrm{O}_{2}[\mathrm{M}+\mathrm{H}]^{+}, 344.1394$; found, 344.1380 .

\section{3-(2-Nitro-1-phenylethyl)-2-phenyl-1H-pyrrolo[2,3-c]pyridine (9h):}

Compound $9 \mathrm{~h}$ was synthesized using general procedure B on $1.2 \mathrm{gm}$ and purified using $10 \%$ $\mathrm{CH}_{3} \mathrm{OH}$ in DCM. Yield: $30 \%$ (brown solid); ${ }^{1} \mathrm{H} \mathrm{NMR}\left(\mathrm{CDCl}_{3}, 500 \mathrm{MHz}\right): \delta 8.93$ (bs, $1 \mathrm{H}$ ), $8.11(\mathrm{~d}, J=5.7,1 \mathrm{H}), 7.54-7.48(\mathrm{~m}, 5 \mathrm{H}), 7.42(\mathrm{~d}, J=5.6 \mathrm{~Hz}, 1 \mathrm{H}), 7.35-7.26(\mathrm{~m}, 5 \mathrm{H}), 5.32(\mathrm{t}$, $J=8.0 \mathrm{~Hz}, 1 \mathrm{H}), 5.15(\mathrm{bs}, 1 \mathrm{H}), 5.13(\mathrm{~d}, J=1.3 \mathrm{~Hz}, 1 \mathrm{H})$; HRMS (ESI): $\mathrm{m} / \mathrm{z}$ calcd for $\mathrm{C}_{21} \mathrm{H}_{17} \mathrm{~N}_{3} \mathrm{O}_{2}[\mathrm{M}+\mathrm{H}]^{+}$, 344.1394; found, 344.1407.

\section{3-(2-Nitro-1-phenylethyl)-2-phenyl-1H-pyrrolo[2,3-b]pyridine (9i):}

Compound 9i was synthesized using general procedure B on $1.5 \mathrm{gm}$ scale and purified using $10 \% \mathrm{CH}_{3} \mathrm{OH}$ in DCM. Yield: 63\% (brown solid); ${ }^{1} \mathrm{H} \mathrm{NMR}\left(\mathrm{CDCl}_{3}, 500 \mathrm{MHz}\right): \delta 12.13$ (bs, $1 \mathrm{H}), 8.07(\mathrm{~d}, J=4.5 \mathrm{~Hz}, 1 \mathrm{H}), 7.82(\mathrm{~d}, J=8.1 \mathrm{~Hz}, 1 \mathrm{H}), 7.61(\mathrm{~d}, J=1.6 \mathrm{~Hz}, 1 \mathrm{H}), 7.59$ (bs, $1 \mathrm{H})$, 7.56-7.50 (m, 3H), 7.33-7.32 (m, 4H), 7.29-7.26 (m, 1H), 7.03(dd, $J=4.5,8.1, \mathrm{~Hz}, 1 \mathrm{H})$, $5.39(\mathrm{t}, J=8.6 \mathrm{~Hz}, 1 \mathrm{H}), 5.17(\mathrm{dd}, J=7.7,12.7 \mathrm{~Hz}, 1 \mathrm{H}), 5.11(\mathrm{dd}, J=9.1,12.4 \mathrm{~Hz}, 1 \mathrm{H}) ;$ HRMS: $\mathrm{m} / \mathrm{z}$ calcd for $\mathrm{C}_{21} \mathrm{H}_{17} \mathrm{~N}_{3} \mathrm{O}_{2}[\mathrm{M}+\mathrm{H}]^{+}, 344.1394$; found, 344.1419 .

\section{3-(1-(3-Fluoropyridin-2-yl)-2-nitroethyl)-2-phenyl-1H-indole (9j):}

Compound $9 \mathbf{j}$ was synthesized using general procedure A. Yield: $90 \% ;{ }^{1} \mathrm{H} \mathrm{NMR}\left(\mathrm{CDCl}_{3}\right.$, $400 \mathrm{MHz}$ ): $\delta 8.40$ (d, $J=5.2 \mathrm{~Hz}, 1 \mathrm{H}), 8.17(\mathrm{~s}, 1 \mathrm{H}), 7.62(\mathrm{~d}, J=7.2 \mathrm{~Hz}, 2 \mathrm{H}), 7.55$ (dd, $J=$ 8.0,14.8 Hz, 3H), 7.46-7.49 (m, 1H), 7.34 (d, J=8.0 Hz, 1H), 7.14-7.24 (m, 3H) 7.01 (t, 
$J=8.0 \mathrm{~Hz}, 1 \mathrm{H}), 5.86(\mathrm{dd}, J=9.6,12.4 \mathrm{~Hz}, 1 \mathrm{H}), 5.65(\mathrm{dd}, J=5.6,10.0 \mathrm{~Hz}, 1 \mathrm{H}), 4.87(\mathrm{dd}, J=5.6$, $14.0 \mathrm{~Hz}, 1 \mathrm{H}) ;{ }^{13} \mathrm{C}$ NMR $\left(100 \mathrm{MHz}, \mathrm{DMSO}-d_{6}\right) \delta 157.44(\mathrm{~d}, J=257.6 \mathrm{~Hz}), 147.46(\mathrm{~d}, J=$ $13.4 \mathrm{~Hz}), 144.56$ (d, $J=5.3 \mathrm{~Hz}), 137.01,136.40,132.77,129.34,129.16,128.63,126.98$, 124.61 (d, $J=3.9 \mathrm{~Hz}), 124.00$ (d, $J=18.1 \mathrm{~Hz}), 121.96,119.70,119.46,112.02,106.15$, 75.34, $36.41(\mathrm{~d}, J=1.8 \mathrm{~Hz})$; HRMS: $\mathrm{m} / \mathrm{z}$ calcd for $\mathrm{C}_{21} \mathrm{H}_{16} \mathrm{FN}_{3} \mathrm{O}_{2}[\mathrm{M}+\mathrm{H}]^{+}, 362.1299$; found, 362.1281 .

\section{2-Phenyl-1H-pyrrolo[3,2-b]pyridine (11d):}

3-Amino-2-methyl pyridine (12) (3 gm, $27.8 \mathrm{mmol}$ ) was dissolved in $30 \mathrm{~mL}$ anhydrous THF in an oven dried two neck round neck flask under argon. The solution was cooled to $-78{ }^{\circ} \mathrm{C}$ and a solution of sec-BuLi (64.15 mL, $83.4 \mathrm{mmol}, 1.3 \mathrm{M}$ in cyclohexane) was added dropwise in $10 \mathrm{~min}$. The solution was warmed to room temperature, stirred at that temperature for $3 \mathrm{~h}$, and cooled to $-78{ }^{\circ} \mathrm{C}$. Ethyl benzoate $(1.98 \mathrm{~mL}, 13.9 \mathrm{mmol})$ was added and the resulting mixture was stirred at $-78{ }^{\circ} \mathrm{C}$ for 1 hour. $20 \mathrm{~mL}$ methanol was added very slowly in $5 \mathrm{~min}$ and the solution was warmed to room temperature slowly and stirred for overnight. The reaction mixture was quenched with sat. $\mathrm{NH}_{4} \mathrm{Cl}$ solution. The aqueous phase was extracted with EtOAc. The combined organic layer was washed with brine $(7 \mathrm{~mL})$ and dried over anhydrous $\mathrm{Na}_{2} \mathrm{SO}_{4}$, filtered, and concentrated under reduced pressure. Purification of the residue on a silica gel column using $10 \% \mathrm{CH}_{3} \mathrm{OH}$ in DCM furnished the corresponding indole 11d as a brown solid [1.5 gm, 39\% (based on starting material recovered, bsmr)] as a brown solid. ${ }^{1} \mathrm{H}$ NMR (DMSO d6, $500 \mathrm{MHz}$ ): $\delta 11.77$ (bs, 1H), 8.29 (dd, $J=1.1,4.4 \mathrm{~Hz}, 1 \mathrm{H}), 7.92(\mathrm{~d}, J=7.3 \mathrm{~Hz}, 2 \mathrm{H}), 7.74$ (d, $J=8.3 \mathrm{~Hz}, 1 \mathrm{H}), 7.50$ (t, $J=7.9 \mathrm{~Hz}$, 2H), $7.38(\mathrm{t}, J=7.4 \mathrm{~Hz}, 1 \mathrm{H}), 7.08(\mathrm{dd}, J=4.8,8.2 \mathrm{~Hz}, 1 \mathrm{H}), 7.06(\mathrm{~d}, J=1.9 \mathrm{~Hz}, 1 \mathrm{H})$.

\section{2-Phenyl-1H-pyrrolo[3,2-c]pyridine (11e):}

To an oven dried round bottom flask $\mathrm{Pd}\left(\mathrm{PPh}_{3}\right)_{2} \mathrm{Cl}_{2}(95 \mathrm{mg}, 0.135 \mathrm{mmol})$ and copper(I) iodide (43 $\mathrm{mg}, 0.230 \mathrm{mmol}$ ) were taken and evacuated under vacuum and then filled with argon. To the flask degassed DMF $(5 \mathrm{~mL})$ were added via cannula, then degassed solution of $\mathrm{N}, \mathrm{N}$-diisopropylethylamine $(2.5 \mathrm{~mL}, 14.5 \mathrm{mmol})$ and 4-amino-3iodopyridine, $\mathbf{1 3}$ (1 gm, 4.5 $\mathrm{mmol}$ ) was added. At the end a degassed solution of phenyl acetylene $(1.05 \mathrm{~mL}, 9.50 \mathrm{mmol})$ in DMF was added. The reaction mixture was stirred for overnight at RT. The reaction mixture was quenched with sat. $\mathrm{NH}_{4} \mathrm{Cl}$ solution. The aqueous phase was extracted with EtOAc. The combined organic layer was washed with brine $(7 \mathrm{~mL})$ and dried over anhydrous $\mathrm{Na}_{2} \mathrm{SO}_{4}$, filtered, and concentrated under reduced pressure. Purification of the residue on a silica gel column using $5 \% \mathrm{CH}_{3} \mathrm{OH}$ in DCM furnished the coupling product [820 $\mathrm{mg}, 93 \%]$ as a brown solid which was used for cyclization reaction.

In an oven-dried RB flask, alkyne amine compound (500 mg, $2.60 \mathrm{mmol})$ and potassium tertbutoxide (577 mg, $5.15 \mathrm{mmol}$ ) were mixed in NMP. The reaction mixture was heated at $100{ }^{\circ} \mathrm{C}$ for 2 hours. After completion of the reaction, the reaction mixture was cooled and quenched with water. The aqueous layer was extracted with ethyl acetate. The combined organic layer was washed with brine $(7 \mathrm{~mL})$ and dried over anhydrous $\mathrm{Na}_{2} \mathrm{SO}_{4}$, filtered, and concentrated under reduced pressure. Purification of the residue on a silica gel column using $10 \% \mathrm{CH}_{3} \mathrm{OH}$ in DCM furnished the cyclized product 11e [456 $\mathrm{mg}, 91 \%$ ] as a brown solid. 
${ }^{1} \mathrm{H}$ NMR (400 MHz, DMSO-d6) $\delta: 11.97$ (s, 1H), $8.82(\mathrm{~s}, 1 \mathrm{H}), 8.17$ (d, $\left.J=4.3 \mathrm{~Hz}, 1 \mathrm{H}\right)$, 7.90 (d, $J=7.3 \mathrm{~Hz}, 2 \mathrm{H}), 7.49$ (t, $J=7.7 \mathrm{~Hz}, 2 \mathrm{H}), 7.38-7.35(\mathrm{~m}, 2 \mathrm{H}), 7.04(\mathrm{~s}, 1 \mathrm{H})$.

\section{2-Phenyl-1H-pyrrolo[2,3-c]pyridine (11f):}

3-Amino-4-methyl pyridine, 14 (2.5 gm g, $0.023 \mathrm{~mol})$ was dissolved in $50 \mathrm{~mL}$ anhydrous THF in an oven dried two neck round neck flask under argon. The solution was cooled to $-78^{\circ} \mathrm{C}$ and a solution of s-BuLi ( $53 \mathrm{~mL}, 0.069 \mathrm{mmol}, 1.3 \mathrm{M}$ in cyclohexane) was added dropwise in $10 \mathrm{~min}$. The solution was warmed to room temperature, stirred at that temperature for 3 hours, and cooled to $-78^{\circ} \mathrm{C}$. Ethyl benzoate $(1.65 \mathrm{~mL}, 0.011 \mathrm{mmol})$ was added and the resulting mixture was stirred at $-78^{\circ} \mathrm{C}$ for 1 hour. $20 \mathrm{~mL}$ methanol was added very slowly in $5 \mathrm{~min}$ and the solution was warmed to room temperature slowly and stirred for overnight. The reaction mixture was quenched with sat. $\mathrm{NH}_{4} \mathrm{Cl}$ solution. The aqueous phase was extracted with EtOAc. The combined organic layer was washed with brine $(7 \mathrm{~mL})$ and dried over anhydrous $\mathrm{Na}_{2} \mathrm{SO}_{4}$, filtered, and concentrated under reduced pressure. Purification of the residue on a silica gel column using $10 \% \mathrm{CH}_{3} \mathrm{OH}$ in DCM furnished the corresponding indole 11f [1.7 g, 53\% (based on starting material recovered)] as a brown solid. ${ }^{1}$ H NMR (DMSO d6, $500 \mathrm{MHz}$ ): $\delta 12.04$ (bs, 1H), 8.75 (s, 1H), 8.09 (d, $J=4.8 \mathrm{~Hz}$, $1 \mathrm{H}), 7.93(\mathrm{~d}, J=7.5 \mathrm{~Hz}, 2 \mathrm{H}), 7.53-7.50(\mathrm{~m}, 3 \mathrm{H}), 7.40$ (t, d=7.3 Hz, 1H), $6.98(\mathrm{~s}, 1 \mathrm{H})$.

\section{2-Phenyl-1H-pyrrolo[2,3-b]pyridine (11g):}

$\mathrm{N}$-(3-methylpyridin-2-yl)benzamide, 15 (1.05 gm, $4.98 \mathrm{mmol})$ was dissolved in $15 \mathrm{~mL}$ anhydrous THF and cooled to $-78{ }^{\circ} \mathrm{C}$. ${ }^{\mathrm{n}} \mathrm{BuLi}(6 \mathrm{~mL}, 14.9 \mathrm{mmol})$ was added dropwise and stirred for 1 hour at that temp. then reaction mixture was slowly heated to room temp. and stirred for 5 hours. The reaction mixture was quenched with sat. $\mathrm{NH}_{4} \mathrm{Cl}$ solution. The aqueous phase was extracted with EtOAc. The combined organic layer was washed with brine $(7 \mathrm{~mL})$ and dried over anhydrous $\mathrm{Na}_{2} \mathrm{SO}_{4}$, filtered, and concentrated under reduced pressure. Purification of the residue on a silica gel column using $10 \% \mathrm{CH}_{3} \mathrm{OH}$ in DCM furnished the corresponding indole $11 \mathrm{~g}$ [499 $\mathrm{mg}, 52 \%$ ] as a brown solid. ${ }^{1} \mathrm{H}$ NMR (DMSO d6, $500 \mathrm{MHz}): \delta 12.14$ (bs, 1H), 8.20 (dd, $J=1.4,4.4, \mathrm{~Hz}, 1 \mathrm{H}), 7.95-7.92(\mathrm{~m}, 3 \mathrm{H}), 7.47$ (t, $J=7.8 \mathrm{~Hz}, 2 \mathrm{H}), 7.35$ (t, $J=7.3 \mathrm{~Hz}, 1 \mathrm{H}), 7.06$ (dd, $J=4.7,7.8, \mathrm{~Hz}, 1 \mathrm{H}), 6.93(\mathrm{~d}, J=1.9 \mathrm{~Hz}, 1 \mathrm{H})$.

\section{Aqueous Solubility:}

Samples (ranging from 0.9-3.2 mg) were weighed into Whatman vials for thermodynamic solubility analysis in $1 \mathrm{X}$ PBS pH7.4. Phosphate buffered saline solution $(450 \mu \mathrm{L})$ added to the vial for a dose concentration of $2.0-7.1 \mathrm{mg} / \mathrm{mL}$.

1X PBS, pH7.4: Phosphate Buffered Saline solution 10X, PBS (Fisher Bioreagent part number BP399- 500) $50 \mathrm{~mL}$ was added to approximately $450 \mathrm{~mL} \mathrm{HPLC}$ grade $\mathrm{H}_{2} \mathrm{O}$. The volume of the solution was then adjusted to $500 \mathrm{~mL}$ for a total dilution factor of $1: 10$ and a final PBS concentration of $1 \mathrm{X}$.

After shaking at ambient temperature $\left(24.5-26.5^{\circ} \mathrm{C}\right)$ for 24 hours on a rotary shaker at 200RPM, the visible appearance of each powder preparation was noted. Samples were filtered, and the filtrates were injected into the nitrogen detector for quantification on Analiza's Automated Discovery Workstation. The results are reported in $\mu \mathrm{g} / \mathrm{mL}$ and $\mu \mathrm{M}$. 
The equimolar nitrogen response of the detector is calibrated using standards which span the dynamic range of the instrument from 0.08 to $4500 \mu \mathrm{g} / \mathrm{mL}$ nitrogen. The filtrates were quantitated with respect to the calibration curve and the calculated solubility values are corrected for background nitrogen in the buffer.

\section{Kinetic Aqueous Solubility:}

The kinetic water solubility of each tested compound was measured by using a Turbidimetric solubility assay; the assays were performed by Cyprotex. Each compound was prepared as a 100X stock solution in DMSO from which serial dilutions were performed to yield eight test article solutions; the micromolar concentrations for the test article solutions were 1.6, 3.21, 6.25, 12.5, 25, 50, 100, and 200. The test article solutions were spotted in a 96-well plate then diluted 100-fold in PBS buffer $(\mathrm{pH}=7.4)$; the diluted test articles in PBS buffer were mixed then incubated for two hours. Ensuing two-hour incubation, absorbance was measured at $540 \mathrm{~nm}$; an absorbance value greater than $3 \mathrm{X}$ standard deviation of the average blank absorption value was considered turbidity. The highest test article concentration with no sign of turbidity represented the kinetic water solubility value of the compound.

\section{Microsomal Stability:}

Microsomal stability assays were performed by Cyprotex; both human and rat liver microsomes were utilized. Each test compound was prepared as a $1 \mu \mathrm{M}$ solution in DMSO, then incubated at $37^{\circ} \mathrm{C}$ with $0.3 \mathrm{mg} / \mathrm{mL}$ microsomal protein, $100 \mathrm{mM}$ PBS buffer $(\mathrm{pH}=$ 7.4), $2 \mathrm{mM} \mathrm{NADPH}$, and $3 \mathrm{mM} \mathrm{MgCl2}$; a control void of NADPH was included for each assay to detect NADPH-free degradation. An aliquot was taken from the reaction mixture at 0 minutes, 5 minutes, 15 minutes, 30 minutes, and 45 minutes from the start of incubation; each aliquot taken was treated with an equal volume of ice-cold methanol containing internal standards to halt the reaction and precipitate proteins. The quenched aliquot was centrifuged to remove proteins then the supernatant was analyzed by LC-MS/MS to determine $\%$ remaining. The $\%$ of parent compound remaining for each time point was plotted to fit a first order decay model for calculating the slope, $\mathrm{k}$, which inturn was used for calculating the half-life from the formula $\mathrm{t} 1 / 2=0.693 / \mathrm{k}$. The calculated half-life was then used to calculate the intrinsic clearance using the formula CLint $=\ln (2) / \mathrm{t} 1 / 2$.

\section{Biological evaluation:}

As we have done previously with our parent compound $\mathbf{6 d}$ (GAT211) ${ }^{25}$, we chose to characterize these newly synthesized analogues by use of standard functional assays.

\section{Compounds used:}

All compounds and reagents were purchased from Sigma-Aldrich (Mississauga ON), unless otherwise noted. CP55,940 was purchased from Cayman Chemical (Ann Arbor, MI). All compounds were initially dissolved in DMSO and diluted in a 10\% DMSO solution in PBS. Compounds were added directly to cell culture at the times and concentrations indicated at a final concentration of $0.1 \%$ DMSO. 


\section{Cell culture:}

HitHunter® (cAMP) and PathHunter® (ßarrestin2) CHO-K1 cells stably-expressing human CB1R (hCB1R) from DiscoveRx $®$ (Eurofins, Fremont, CA) were maintained between passage 5-35 at $37^{\circ} \mathrm{C}, 5 \% \mathrm{CO}_{2}$ in F-12 DMEM (Corning Cellgro, Manassas VA) containing $10 \%$ FBS and $1 \%$ penicillin-streptomycin with $800 \mu \mathrm{g} / \mathrm{mL}$ geneticin (HitHunter $($ ) or 800 $\mu \mathrm{g} / \mathrm{mL}$ geneticin and $300 \mu \mathrm{g} / \mathrm{mL}$ hygromycin B (PathHunter $\left.{ }^{\circledR}\right)$. HitHunter ${ }^{\circledR}$ and PathHunter ${ }^{\circledR}$ hCB1R CHO-K1 cells were used for data presented in tables 1, 2, and 4 and figure 5. $\mathrm{CHO}$ cells stably transfected with cDNA encoding human cannabinoid $\mathrm{CB}_{1}$ Rs were maintained at $37^{\circ} \mathrm{C}$ and $5 \% \mathrm{CO}_{2}$ in Ham's F-12 Nutrient Mix, supplemented both with 2 $\mathrm{mM}$ L-glutamine, $10 \% \mathrm{FBS}$ and $0.6 \%$ penicillin-streptomycin, all also supplied by (Gibco $^{\mathrm{TM}}$, Fisher Scientific UK Ltd), and the disulphate salt of G418 [(2R,3S,4R,5R,6S)-5amino-6-\{[(1R,2S,3S,4R,6S)-4,6-diamino-3\{[(2R,3R,4R,5R)-3,5-dihydroxy-5-methyl-4(methylamino)oxan-2-yl]oxy\}-2-hydroxy cyclohexyl]oxy \}-2-[(1R)-1hydroxyethyl]oxane-3,4-diol; $600 \mathrm{mg} \cdot \mathrm{mL}^{-1}$ ] ( Sigma-Aldrich UK). All cells were exposed to $5 \% \mathrm{CO}_{2}$ in their media, and were passaged twice a week using nonenzymatic cell dissociation solution. For membrane preparation, cells were removed from flasks by scraping, centrifuged, and then frozen as a pellet at $-20^{\circ} \mathrm{C}$ until required. Before use in a radioligand binding assay, cells were defrosted, diluted in Tris buffer $(50 \mathrm{mM}$ Tris- $\mathrm{HCl}$ and 50 mM Tris-base). Human Embryonic Kidney (HEK293; American Type Culture Collection, Rockville, MD) cells were cultured in DMEM supplemented with 10\% FBS (GE Healthcare Hyclone Laboratories, Logan UT). HEK293 cells stably expressing GFP-tagged (N-terminus) GFP-rCB1R were generated as previously described. Briefly, HEK293 cells were transfected with GFP-rCB1R-pcDNA3.1 using Lipofectamine 2000 (Invitrogen, Carlsbad CA) and selected in DMEM containing 10\% FBS and geneticin $(800 \mu \mathrm{g} / \mathrm{mL})$. Colonies were picked 2 weeks after transfection and allowed to expand before analysis of GFP-tagged receptor expression by fluorescence microscopy. Cell lines with moderate to high receptor expression were maintained in DMEM with $10 \% \mathrm{FBS}$ and $500 \mu \mathrm{g} / \mathrm{mL}$ geneticin.

\section{HitHunter ${ }^{\circledR}$ CAMP assay:}

Inhibition of forskolin-stimulated cAMP was determined using the DiscoveRx® HitHunter ${ }^{\circledR}$ assay in hCB1R CHO-K1 cells. Cells (20,000 cells/well in low-volume 96 well plates) were incubated overnight in Opti-MEM (Invitrogen) containing $1 \% \mathrm{FBS}$ at $37^{\circ} \mathrm{C}$ and $5 \% \mathrm{CO}_{2}$. Following this, Opti-MEM media was removed and replaced with cell assay buffer (DiscoveRx) and cells were co-treated at $37^{\circ} \mathrm{C}$ with $10 \mu \mathrm{M}$ forskolin and hCB1R ligands $(0.10 \mathrm{nM}-10 \mu \mathrm{M})$ for $30 \mathrm{~min}$ (Tables 1 and 2; Suppl Fig. 1) or 90 min (Table 4; Fig. 5). cAMP antibody solution and cAMP working detection solutions were then added to cells according to the manufacturer's directions (DiscoveRx ${ }^{\circledR}$ ) and cells were incubated for 60 min at room temperature. cAMP solution A was added according to the manufacturer's directions (DiscoveRx ${ }^{\circledR}$ ) and cells were incubated for an additional $60 \mathrm{~min}$ at room temperature before chemiluminescence was measured on a Cytation 5 plate reader (top read, gain 200, integration time 10,000 ms). Standard agonist properties in the assays used were as follows: CP55,940: $\mathrm{EC}_{50}=3.6 \pm 1.7 \mathrm{nM} ; E_{\mathrm{Max}}=1.5 \pm 0.07$ (fold over baseline). $n \geq 6$ individual experiments performed in triplicate. 


\section{PathHunter ${ }^{\circledR}$ CB1R $\beta$ arrestin2 assay:}

ßarrestin2 recruitment was determined using the hCB1R CHO-K1 cell PathHunter ${ }^{\circledR}$ assay (DiscoveRx®). Cells (20,000 cells/well in low-volume 96 well plates) were incubated overnight in Opti-MEM (Invitrogen) containing $1 \% \mathrm{FBS}$ at $37^{\circ} \mathrm{C}$ and $5 \% \mathrm{CO}_{2}$. Following this, cells were co-treated at $37^{\circ} \mathrm{C}$ with hCB1R ligands $(0.10 \mathrm{nM}-10 \mu \mathrm{M})$ for $90 \mathrm{~min}$ (Fig. 3; Tables 1, 2, 5; Suppl Fig. 1). Detection solution was then added to cells according to the manufacturer's directions (DiscoveRx ${ }^{\circledR}$ ) and cells were incubated for $60 \mathrm{~min}$ at room temperature. Chemiluminescence was measured on a Cytation 5 plate reader (top read, gain 200 , integration time $10,000 \mathrm{~ms}$ ). Standard agonist properties in the assays used were as follows: $\mathrm{CP} 55,940: \mathrm{EC}_{50}=34 \pm 4.4 \mathrm{nM} ; E_{\mathrm{Max}}=8.0 \pm 1.3$ (fold over baseline). $n \geq 6$ individual experiments performed in triplicate.

\section{Detection of cAMP:}

HEK293 cells stably expressing GFP-hCB1R were plated in a 24-well plate and cultured until 70-80\% confluent. Cells were then dissociated in Trypsin (0.05\%)-EDTA (0.1\%) (Quality Biological, Gaithersburg MD), centrifuged at 200g for $5 \mathrm{~min}$ and resuspended in Hank's Balanced Salt Solution (HBSS) (Corning Cellgro) containing 0.1\% BSA and 0.5mM IBMX (Sigma-Aldrich, St. Louis MO). Cells in suspension were transferred to a white 384well plate at a density of 500 cells/well and treated with $5 \mu \mathrm{M}$ forskolin (Cayman Chemical, Ann Arbor MI) along with different concentration of designated compounds for $30 \mathrm{~min}$. After drug treatment, cAMP levels were detected using the LANCE Ultra cAMP detection kit (PerkinElmer, Waltham MA) according to manufacturer's instructions. In this timeresolved fluorescence resonance energy transfer (TR-FRET) immunoassay, cells are lysed and incubated with europium (Eu) chelate-labeled cAMP and ULight ${ }^{\mathrm{TM}}$ dye-labeled monoclonal antibody directed against cAMP. After at least $1 \mathrm{~h}$ incubation, light emission at $665 \mathrm{~nm}$ was measured in an EnVision 2104 multilabel plate reader (PerkinElmer).

Fluorescence counts were used to estimate cAMP concentration in samples based on a cAMP standard curve. The cAMP concentration in each sample was normalized to cAMP levels in samples treated only with $5 \mu \mathrm{M}$ forskolin. Data was then fitted to a four-parameter least squares nonlinear regression analysis using GraphPad Prism 7.05 (GraphPad Software, San Diego CA).

\section{[ $\left.{ }^{3} \mathrm{H}\right] \mathrm{CP} 55940$ Radioligand displacement assay:}

The assays were carried out with $\left[{ }^{3} \mathrm{H}\right] \mathrm{CP} 55940$ and Tris binding buffer $(50 \mathrm{mM}$ Tris- $\mathrm{HCl}$, $50 \mathrm{mM}$ Tris-base, $0.1 \%$ BSA, pH 7.4), total assay volume $500 \mu$ l. Binding was initiated by the addition of transfected human $\mathrm{CB}_{1} \mathrm{CHO}$ cell membranes ( $50 \mu \mathrm{g}$ protein per well). All assays were performed at $37^{\circ} \mathrm{C}$ for $60 \mathrm{~min}$ before termination by the addition of ice-cold Tris binding buffer, followed by vacuum filtration using a 24-well sampling manifold (Brandel Cell Harvester; Brandel Inc, Gaithersburg, MD, USA) and Brandel GF/B filters that had been soaked in wash buffer at $4^{\circ} \mathrm{C}$ for at least $24 \mathrm{~h}$. Each reaction well was washed six times with a $1.2 \mathrm{~mL}$ aliquot of Tris-binding buffer. The filters were oven-dried for $60 \mathrm{~min}$ and then placed in $3 \mathrm{~mL}$ of scintillation fluid (Ultima Gold XR, PerkinElmer, Seer Green, Buckinghamshire, UK). Radioactivity was quantified by liquid scintillation spectrometry. Specific binding was defined as the difference between the binding that occurred in the 
presence and absence of $1 \mu \mathrm{M}$ unlabeled CP55940. The concentration of [ $\left.{ }^{3} \mathrm{H}\right] \mathrm{CP} 55940$ used in our displacement assays was $0.7 \mathrm{nM}$. The compounds used in this investigation were stored as stock solutions of $10 \mathrm{mM}$ in DMSO, the vehicle concentration in all assay wells being $0.1 \%$ DMSO. Data are presented as \% ligand bound.

\section{[ $\left.{ }^{3} \mathrm{H}\right] \mathrm{SR} 141716 \mathrm{~A}$ Radioligand displacement assay:}

Assays were carried out with $\left[{ }^{3} \mathrm{H}\right] \mathrm{SR} 141716 \mathrm{~A}$ and Tris binding buffer (75 mM Tris, 12.5 $\mathrm{mM} \mathrm{MgCl} 2,1 \mathrm{mM}$ EDTA, $1 \% \mathrm{BSA}, \mathrm{pH} 7.4)$, total assay volume $200 \mu \mathrm{L}$. Binding was initiated by the addition of transfected human $\mathrm{CB}_{1} \mathrm{CHO}$ cell membranes $(25 \mu \mathrm{g}$ protein per well). All assays were performed at room temperature for $2 \mathrm{~h}$ before termination by the addition of ice-cold Tris binding buffer, followed by vacuum filtration using a Millipore Sigma 12-well sampling manifold and Brandel GF/B filters that had been soaked in wash buffer at $4^{\circ} \mathrm{C}$ for at least $24 \mathrm{~h}$. Each reaction well was washed three times with a $2 \mathrm{~mL}$ aliquot of Tris-binding buffer. The filters were oven-dried for $60 \mathrm{~min}$ and then placed in 5 $\mathrm{mL}$ of scintillation fluid (Ultima Gold F, PerkinElmer, Billerica, MA). Radioactivity was quantified by liquid scintillation spectrometry. Specific binding was defined as the difference between the binding that occurred in the presence and absence of $1 \mu \mathrm{M}$ unlabelled SR141716A. The concentration of $\left[{ }^{3} \mathrm{H}\right] \mathrm{SR} 141716 \mathrm{~A}$ used in our displacement assays was 1.0 $\mathrm{nM}$. The compounds used in this investigation were stored as stock solutions of $10 \mathrm{mM}$ in DMSO, the vehicle concentration in all assay wells being 0.1\% DMSO. Data are presented as $\%$ ligand bound.

\section{$\left.{ }^{35} \mathrm{~S}\right] \mathrm{GTP} \gamma \mathrm{S}$ assay:}

The assay was carried out in the presence of $\left[{ }^{35} \mathrm{~S}\right] \mathrm{GTP} \gamma \mathrm{S}(0.1 \mathrm{nM})$, GDP $(30 \mu \mathrm{M}), \mathrm{GTP} \gamma \mathrm{S}$ $(30 \mu \mathrm{M})$ and $\mathrm{CHO}$ cell membranes $(1 \mathrm{mg} / \mathrm{mL})$ overexpressing $h \mathrm{CB}_{1}$ Rs. The assay buffer contained $50 \mathrm{mM}$ Tris, $10 \mathrm{mM} \mathrm{MgCl}_{2}, 100 \mathrm{mM} \mathrm{NaCl}, 0.2 \mathrm{mM}$ EDTA and $1 \mathrm{mM}$ DTT (dithiothreitol) at $\mathrm{pH}$ 7.4. Incubations were carried out at $30{ }^{\circ} \mathrm{C}$ for $90 \mathrm{~min}$ in a total volume of $500 \mathrm{~mL}$. The reaction was terminated by the addition of ice-cold wash buffer $(50 \mathrm{mM}$ Tris and $1 \mathrm{mg} / \mathrm{mL}$ BSA, $\mathrm{pH}$ 7.4) followed by rapid filtration under vacuum through Whatman GF/B glass-fibre filters (pre-soaked in wash buffer) 24-well sampling manifold (Brandel Cell Harvester; Brandel Inc, Gaithersburg, MD, USA) and Brandel GF/B filters that had been soaked in wash buffer at $4^{\circ} \mathrm{C}$ for at least $24 \mathrm{~h}$. Each reaction well was washed six times with a $1.2 \mathrm{~mL}$ aliquot of Tris-binding buffer. The filters were oven-dried for $60 \mathrm{~min}$ and then placed in $3 \mathrm{~mL}$ of scintillation fluid (Ultima Gold XR, PerkinElmer, Seer Green, Buckinghamshire, UK). Bound radioactivity was determined by liquid scintillation counting. Basal binding of $\left[{ }^{35} \mathrm{~S}\right] \mathrm{GTP} \gamma \mathrm{S}$ was determined in the presence of $20 \mathrm{mM}$ GDP and absence of cannabinoid. Non-specific binding was determined in the presence of $10 \mathrm{mM} \mathrm{GTP \gamma S}$. The compounds used in this investigation were stored as stock solutions of $10 \mathrm{mM}$ in DMSO, the vehicle concentration in all assay wells being $0.1 \%$ DMSO.

\section{Hippocampal culture preparation:}

All procedures used in this study were approved by the Animal Care Committee of Indiana University and conform to the Guidelines of the National Institutes of Health on the Care and Use of Animals. Mouse hippocampal neurons isolated from the CA1-CA3 region were cultured on microislands as described previously ${ }^{62,63}$. Neurons were obtained from mice 
(C57Bl/6, postnatal day 0-2, of indeterminate sex) and plated onto a feeder layer of hippocampal astrocytes that had been laid down previously ${ }^{64}$. Cultures were grown in highglucose $(20 \mathrm{mM})$ DMEM containing $10 \%$ horse serum, without mitotic inhibitors and used for recordings after 8 days in culture and for no more than three hours after removal from culture medium. ${ }^{65}$

\section{Electrophysiology:}

When a single neuron is grown on a small island of permissive substrate, it forms synapses —or "autapses"—onto itself. All experiments were performed on isolated autaptic neurons. Whole cell voltage-clamp recordings from autaptic neurons were carried out at room temperature using an Axopatch 200A amplifier (Axon Instruments, Burlingame, CA). The extracellular solution contained (in $\mathrm{mM}$ ) $119 \mathrm{NaCl}, 5 \mathrm{KCl}, 2.5 \mathrm{CaCl}_{2}, 1.5 \mathrm{MgCl}_{2}, 30$ glucose, and 20 HEPES. Continuous flow of solution through the bath chamber $(\sim 2 \mathrm{~mL} /$ min) ensured rapid drug application and clearance. Drugs were typically prepared as stocks, and then diluted into extracellular solution at their final concentration and used on the same day.

Recording pipettes of 1.8-3 $\mathrm{M} \Omega$ were filled with (in $\mathrm{mM}$ ) 121.5 KGluconate, $17.5 \mathrm{KCl}, 9$ $\mathrm{NaCl}, 1 \mathrm{MgCl}_{2}$, 10 HEPES, 0.2 EGTA, $2 \mathrm{MgATP}$, and $0.5 \mathrm{LiGTP}$. Access resistance and holding current were monitored and only cells with both stable access resistance and holding current were included for data analysis. Conventional stimulus protocol: the membrane potential was held at $-70 \mathrm{mV}$ and excitatory postsynaptic currents (EPSCs) were evoked every 20 seconds by triggering an unclamped action current with a $1.0 \mathrm{~ms}$ depolarizing step. The resultant evoked waveform consisted of a brief stimulus artifact and a large downward spike representing inward sodium currents, followed by the slower EPSC. The size of the recorded EPSCs was calculated by integrating the evoked current to yield a charge value (in pC). Calculating the charge value in this manner yields an indirect measure of the amount of neurotransmitter released while minimizing the effects of cable distortion on currents generated far from the site of the recording electrode (the soma). Data were acquired at a sampling rate of $5 \mathrm{kHz}$.

\section{DSE stimuli:}

After establishing a 10-20 second $0.5 \mathrm{~Hz}$ baseline, DSE was evoked by depolarizing to 0 $\mathrm{mV}$ for $50 \mathrm{~ms}, 100 \mathrm{~ms}, 300 \mathrm{~ms}, 500 \mathrm{~ms} 1 \mathrm{~s}, 3 \mathrm{~s}$ and $10 \mathrm{~s}$, followed in each case by resumption of a $0.5 \mathrm{~Hz}$ stimulus protocol for $20-80+$ seconds, allowing EPSCs to recover to baseline values. This approach allowed us to determine the sensitivity of the synapses to DSE induction. To allow comparison, baseline values (prior to the DSE stimulus) are normalized to one. DSE inhibition values are presented as fractions of 1, i.e. a 50\% inhibition from the baseline response is $0.50 \pm$ standard error of the mean. The $\mathrm{x}$-axis of DSE depolarization-response curves are log-scale seconds of the duration of the depolarization used to elicit DSE. Depolarization response curves are obtained to determine pharmacological properties of endogenous 2-AG signaling by depolarizing neurons for progressively longer durations $(50 \mathrm{~ms}, 100 \mathrm{~ms}, 300 \mathrm{~ms}, 500 \mathrm{~ms}, 1 \mathrm{sec}, 3 \mathrm{~s}$ and $10 \mathrm{~s}$ ). 


\section{Triad assessment in mice:}

Male C57BL/6 mice between 4- 7 months of age were utilized for these studies.

Compounds administered intraperitoneally (i.p.) were prepared in vehicle [DMSO and cremaphor in saline (1:1:8)]. Mouse weight was recorded daily. Catalepsy was assessed in the bar holding assay $5 \mathrm{~min}$ after drug administration. ${ }^{22}$ Mice were placed such that their forepaws clasped a $0.7 \mathrm{~cm}$ ring clamp positioned $4.5 \mathrm{~cm}$ above the surface of the testing space. The length of time the ring was held was recorded $(\mathrm{sec})$. The trial was ended if the mouse turned its head or body or made 3 consecutive escape attempts. ${ }^{22}$ Body temperature was measured by rectal thermometer $15 \mathrm{~min}$ after drug administration. Antinociceptive effects were assessed in the warm water $\left(52^{\circ} \mathrm{C}\right)$ tail-flick test 20 min after drug administration. Response was defined as the removal of the tail from the warm water, with a threshold time of $20 \mathrm{sec}$. Catalepsy and tail flick data are presented as \% maximum possible effect (MPE). ${ }^{66}$ Locomotor effects were not assessed in an open field paradigm to minimize animal handling and stress, as previous studies have demonstrated cannabimimetic effects are sufficiently observed without open field assessment. ${ }^{22,66}$

Baseline measurements of catalepsy, temperature, and anti-nociception were taken at the beginning of the study in untreated animals. Compounds were administered at the doses indicated. Experimenters were blinders to treatment for all behavioral assessments and analyses. In all cases, experiments were performed with the approval of the University Animal Care Committee (UACC) and Scientific Merit Review Committee for Animal-Based Research (SMRCABR) at the University of Saskatchewan and are in keeping with the guidelines of the Canadian Council on Animal Care (CCAC) and the ARRIVE guidelines. ${ }^{67}$

\section{Ocular pressure assessment in mice:}

Normotensive C57B1/6J mice and Sh3pxd2b mice were obtained from Jackson Laboratory (Bar Harbor, Maine). The Sh3pxd2b mice were bred in house, and their progenies with abnormal phenotypical morphology, identified as a nee mice, were used for experiments.

\section{Drugs:}

GAT592 was synthetized in Dr. Thakur's Laboratory at the Northeastern University, Boston, MA. Each drug was dissolved in a standard vehicle containing 2\% DMSO (Sigma Aldrich, Oakville, ON, Canada) and 4\% Tween-20 (Sigma-Aldrich) in Tocrisolve ${ }^{\mathrm{TM}}$ (Bio-Techne, Minneapolis, MN). In normotensive C57B1/6J animals WIN55,212-2 (0.25\%) was dissolved together with GAT592 (0.2\%). In the ocular hypertensive nee mice GATs were administered alone at $0.2 \%$. Drugs were administered topically ( $5 \mu \mathrm{L} /$ eye) to the right eyes, while the left eyes received vehicle control ( $2 \% \mathrm{DMSO}+4 \%$ Tween- 20 in Tocrisolve ${ }^{\mathrm{TM}} ; 5 \mu \mathrm{L}$ ).

\section{IOP Measurements:}

Mice were anesthetized with the isoflurane (3\% induction, $1.5 \%$ maintenance). The intraocular pressure (IOP) was measured with a handheld rebound tonometer (Tonolab, Icare, Finland), calibrated to mouse. Ten recording were taken for each eye and then averaged. The IOP readings were taken at time 0 (baseline), 1, 6 and $12 \mathrm{hrs}$ after the drug/ vehicle administration. All the measurements were taken at the same time of the day, in order to minimize variability related to diurnal changes in IOP. Data was analyzed by 
GraphPad version 6.0 (GraphPad Software, Inc., La Jolla, CA). Paired t-tests were used to compare between eyes of the same animal. A $P$ value of $<0.05$ was considered.

\section{Evaluation of $6 r$ and $6 s$ in CFA model:}

Subjects: Wild type CD1 male adult mice $(30 \pm 10 \mathrm{~g})$ were purchased from Charles River laboratories (Wilmington, MA) or bred at Indiana University. CB1 knockout (KO) mice on a CD1 background strain were bred and genotyped at Indiana University. Animals were single-housed at relatively constant temperature $\left(73 \pm 2^{\circ} \mathrm{F}\right)$ and humidity $(45 \%)$ under lightdark cycles of 12/12 h. All the experimental procedures were approved by Bloomington Institutional Animal Care and Use Committee of Indiana University and followed the guidelines for the treatment of animals of the International Association for the Study of Pain (Zimmermann, 1983).

Chemicals: 6r and 6s were dissolved in a vehicle of dimethysulfoxide (Sigma-Aldrich, St. Louis, MO), Emulphor (Alkamuls EL 620L, Solvay, Princeton, NJ), ethanol (SigmaAldrich), and sterile saline (Aquilite System, Hospira Inc., Lake Forest, IL) in a ratio of 5:2:2:16, respectively. Drugs were delivered via intraperitoneal (i.p.) injection in a volume of $10 \mathrm{~mL} / \mathrm{kg}$.

Complete Freunds Adjuvant (CFA)-Induced Inflammatory Nociception: A single intraplantar (i.pl.) injection of complete Freund's adjuvant (CFA) and saline (at ratio of 1:1; $20 \mu \mathrm{L}$ total volume) was delivered unilaterally into the plantar surface of the right hind paw.

Assessment of Mechanical Allodynia: Mice were placed in individual transparent Plexiglass chambers on an elevated mesh platform and allowed to habituate to the test chamber for a minimum of 30 minutes prior to testing. A semi-flexible tip connected to an electronic vonFrey anesthesiometer (IITC Life Science Inc., Woodland Hills, CA) was applied vertically to the midplantar region of the hind paw with gradually increased force as described previously. ${ }^{68}$ The force in grams (g) that was applied to the plantar surface of the hindpaw and elicited paw withdrawal was recorded. Each paw was tested twice, with an interval of several minutes separating successive stimulations of the same paw to avoid behavioral sensitization to mechanical stimulation. Mechanical paw withdrawal thresholds $(\mathrm{g})$ were averaged for each paw.

General In Vivo Experimental Protocol: The experimenter was blinded to the treatment condition, and all mice were randomly assigned to experimental conditions. Effects of pharmacological manipulations were assessed during the maintenance phase of CFA induced inflammatory pain (i.e., beginning 48 hours after CFA injection). Mechanical paw withdrawal thresholds were assessed in duplicate in each paw before and 30 minutes after drug administration or at the post-injection timepoints specified (i.e. 0.5, 1.5, 2.5 or 4 h). The impact of ascending doses of GAT591 (0.1, 0.3, 1, 3, 10, $30 \mathrm{mg} / \mathrm{kg}$, i.p.) or GAT593 $(0.1,0.3,1,3,10,30 \mathrm{mg} / \mathrm{kg}$, i.p.) was assessed within subjects at $3 \mathrm{~h}$ intervals across 2 successive days. Three doses were tested on each day in ascending order. 
Statistical Analysis: Two-way mixed ANOVA was used to analyze the main effect of drug treatments, and main effect of groups, as well as interaction between drug treatments and groups. Bonferroni post hoc test was performed for all pairwise comparisons. SPSS 24 (IBM Corporation, Armonk, NY) was used to analyze in vivo data. $\mathrm{P}<0.05$ was considered statistically significant. Data was graphed using GraphPad Prism version 5.02 (GraphPad Software, San Diego, CA). Data are expressed as mean \pm S.E.M.

Concentration-response curve data analysis and statistics: Data are presented as the mean \pm the standard error of the mean (S.E.M.) or $95 \%$ confidence interval (C.I.) of at least 3 independent experiments conducted in duplicate or triplicate, as indicated. Significance was determined by non-overlapping $95 \%$ C.I. or by one- or two-way ANOVA followed by Tukey's or Bonferroni's post-hoc test, as indicated. $P<0.05$ was considered significant. Concentration-response curves for are presented as $\%$ forskolin response for HEK293 cell (Fig. 2, 3), \% bound (Fig. 4a,b), \% stimulation over baseline (Fig. 4c, d), \% compound maximum for CHO hCB1R cAMP HitHunter cells (Fig. 5), or \% CP55,940 response for $\mathrm{CHO}$ hCB1R $\beta$ arrestin2 PathHunter cells (Fig. 5). ${ }^{69}$ Agonist concentrationresponse curves were fit to a nonlinear regression (4 parameter) model to determine $\mathrm{EC}_{50}$ and $E_{\mathrm{Min}}$, and $E$ Max in Prism (v. 7, GraphPad Software Inc., San Diego, CA). In order to calculate agonist bias, concentration-response curves were globally fit to the operational model (eq. 1 ; Prism). ${ }^{69-71}$

$$
E=\frac{E_{\max }[A]^{n} \tau^{n}}{[A]^{n} \tau^{n}+\left([A]+K_{A}\right)^{n}}
$$

To best fit data, the transduction coefficient $\log \left(\tau / K_{\mathrm{A}}\right)$ (i.e. $\left.\operatorname{logR}\right), n$, and $E_{\mathrm{Max}}$ are shared across datasets and $\log K_{\mathrm{A}}$ is constrained between 0 and $-15 .{ }^{69,71}$ Relative agonist activity compared to a reference agonist (CP55,940 as indicated) is calculated as follows:

$$
\Delta \log R=\log \left(\tau / K_{A}\right)_{\text {Test compound }}-\log \left(\tau / K_{A}\right)_{\text {Ref compound }}
$$

$\Delta \log R$ values are then compared for test compounds between assays measuring inhibition of cAMP and $\beta$ arrestin2 recruitment to determine bias factor $(\Delta \Delta \log R)$ (eq. 3). ${ }^{69,71}$

$$
\begin{aligned}
& \log \text { bias }=\Delta \Delta \log R=\Delta \Delta \log \left(\tau / K_{A}\right)_{R 1-R 2}=\Delta \log \left(\tau / K_{A}\right)_{R 1} \\
& -\Delta \log \left(\tau / K_{A}\right)_{R 2}
\end{aligned}
$$

\section{Supplementary Material}

Refer to Web version on PubMed Central for supplementary material.

\section{ACKNOWLEDGMENT}

Funding Sources

This work was supported by EY024727 (to G.A.T., R.P., A.S., and M.K.), DA047858 (to A.G.H. and K.M.), DA041229 (to A.G.H. and K.M.), DA009158 (to A.G.H., K.M., and M.E.A.), DA013429 (to M.E.A. and L.M.L.), DA007327 (to L.M.L.), DA045698 (to M.E.A. and P.H.R.), and DA003934 (to P.H.R.). This research was also 
funded with support through a partnership grant to R.B.L. from GlaxoSmithKline and the Canadian Institutes of Health Research (386427). T.B. is supported by a research scholarship from the College of Pharmacy and Nutrition, University of Saskatchewan.

\section{ABBREVIATIONS USED}

AEA

2-AG

BSA

bsmr

cAMP

CB1R

CB2R

CHO

CI

bsmr

CNS

DMSO

DCM

EtOAc

$\mathbf{E t}_{\mathbf{3}} \mathbf{N}$

GPCRs

$\left.{ }^{35} \mathrm{~S}\right] \mathrm{GTP} \gamma \mathrm{S}$

HEK293

HPLC

HTS

Hz

$\mathrm{K}_{2} \mathrm{CO}_{3}$

LAPS

LCMS

MHz

$\mathrm{MeOH}$ arachidonoylethanol amine

2-arachidonoylglycerol

bovine serum albumin

based on starting material recovered

cyclic adenosine monophosphate

cannabinoid 1 receptor

cannabinoid 2 receptor

Chinese hamster ovary cells

confidence interval

based on starting material recovered

central nervous system

dimethyl sulfoxide

dichloromethane

ethyl acetate

triethylamine

G-protein-coupled receptors

guanosine $5^{\prime}-\mathrm{O}-\left(3-{ }^{35} \mathrm{~S}\right]$ thio $)$ triphosphate

human embryonic kidney 293 cells

high performance liquid chromatography

high-throughput screening

hertz

potassium carbonate

ligand-assisted protein structure

liquid chromatography mass spectrometry

megahertz

methanol 


\begin{tabular}{|c|c|}
\hline NaBH4 & sodium borohydride \\
\hline NAMs & negative allosteric modulators \\
\hline $\mathrm{Na}_{2} \mathrm{SO}_{4}$ & sodium sulfate \\
\hline NaOAc & sodium acetate \\
\hline $\mathrm{NaHCO}_{3}$ & sodium bicarbonate \\
\hline $\mathrm{NaNO}_{2}$ & sodium nitrite \\
\hline $\mathrm{NH}_{4} \mathrm{OAc}$ & ammonium acetate \\
\hline $\mathrm{NH}_{4} \mathrm{Cl}$ & ammonium chloride \\
\hline NMR & nuclear magnetic resonance spectroscopy \\
\hline NMP & N-methylpyrrolidinone \\
\hline PPA & polyphosphoric acid \\
\hline THF & tetrahydrofuran \\
\hline TLC & thin layer chromatography \\
\hline SAR & structure-activity relationship \\
\hline SEM & standard error of mean \\
\hline Tris & tris(hydroxymethyl)- aminomethane \\
\hline $\mathbf{U V}$ & ultraviolet \\
\hline rt & room temperature \\
\hline
\end{tabular}

\section{REFERENCES:}

1. Pertwee RG, Endocannabinoids and Their Pharmacological Actions In: Pertwee R (eds) Endocannabinoids. Handbook of Experimental Pharmacology, vol 231 Springer, Cham, 2015; pp 137. [PubMed: 26408156]

2. Jung SW; Cho AE; Yu W, Exploring the Ligand Efficacy of Cannabinoid Receptor 1 (CB1) using Molecular Dynamics Simulations. Sci. Rep 2018, 8, 13787. [PubMed: 30213978]

3. Pertwee RG, Ligands that Target Cannabinoid Receptors in the Brain: from THC to Anandamide and Beyond. Addict. Biol 2008, 13, 147-159. [PubMed: 18482430]

4. Aizpurua-Olaizola O; Elezgarai I; Rico-Barrio I; Zarandona I; Etxebarria N; Usobiaga A, Targeting the Endocannabinoid System: Future Therapeutic Strategies. Drug Discov. Today 2017, 22, 105110. [PubMed: 27554802]

5. Di Marzo V, Targeting the Endocannabinoid System: to Enhance or Reduce? Nat. Rev. Drug Discov 2008, 7, 438-455. [PubMed: 18446159]

6. Janero DR, Cannabinoid-1 Receptor (CB1R) Blockers as Medicines: Beyond Obesity and Cardiometabolic Disorders to Substance Abuse/Drug Addiction with CB1R Neutral Antagonists. Expert Opin. Emerg. Drugs 2012, 17, 17-29. [PubMed: 22335400]

7. Jung SW; Cho AE; Yu W, Exploring the Ligand Efficacy of Cannabinoid Receptor 1 (CB1) using Molecular Dynamics Simulations. Sci. Rep 2018, 8, 13787. [PubMed: 30213978] 
8. Lu Y; Anderson HD, Cannabinoid Signaling in Health and Disease. Can. J. Physiol. and Pharmacol. 2017, 95, 311-327. [PubMed: 28263083]

9. Marzo VD; Bifulco M; Petrocellis LD, The Endocannabinoid System and its Therapeutic Exploitation. Nat. Rev. Drug Discov. 2004, 3, 771-784. [PubMed: 15340387]

10. Pacher P; Bátkai S; Kunos G, The Endocannabinoid System as an Emerging Target of Pharmacotherapy. Pharmacol. Rev 2006, 58, 389-462. [PubMed: 16968947]

11. Vemuri VK; Janero DR; Makriyannis A, Pharmacotherapeutic Targeting of the Endocannabinoid Signaling System: Drugs for Obesity and the Metabolic Syndrome. Physiol Behav 2008, 93, 671686. [PubMed: 18155257]

12. Wang J; Wang Y; Tong M; Pan H; Li D, New Prospect for Cancer Cachexia: Medical Cannabinoid. J. Cancer 2019, 10, 716-720. [PubMed: 30719170]

13. Pertwee RG, Targeting the Endocannabinoid System with Cannabinoid Receptor Agonists: Pharmacological Strategies and Therapeutic Possibilities. Philos. Trans. Royal Soc. B 2012, 367, 3353-3363.

14. Ross RA, Allosterism and Cannabinoid CB(1) Receptors: the Shape of Things to Come. Trends Pharmacol. Sci 2007, 28, 567-572. [PubMed: 18029031]

15. Paula M; Pilar G; Nadine J; Laura H-F, Allosteric Modulators of the CB1 Cannabinoid Receptor: A Structural Update Review. Cannabis and Cannabinoid Research 2016, 1, 22-30. [PubMed: 28861476]

16. Busquets Garcia A; Soria-Gomez E; Bellocchio L; Marsicano G, Cannabinoid Receptor Type-1: Breaking the Dogmas. F1000Research 2016, 5, F1000 Faculty Rev-990.

17. Abood ME, Allosteric Modulators: A Side Door. J. Med. Chem 2016, 59, 42-43. [PubMed: 26645411]

18. Dopart R; Lu D; Lichtman AH; Kendall DA, Allosteric Modulators of Cannabinoid Receptor 1: Developing Compounds for Improved Specificity. Drug Metab. Rev 2018, 50, 3-13. [PubMed: 29355030]

19. Alaverdashvili M; Laprairie RB, The Future of Type 1 Cannabinoid Receptor Allosteric Ligands. Drug Metab. Rev 2018, 50, 14-25. [PubMed: 29355038]

20. Janero DR; Thakur GA, Leveraging Allostery to Improve G Protein-Coupled Receptor (GPCR)Directed Therapeutics: Cannabinoid Receptor 1 as Discovery Target. Expert Opin Drug Discov. 2016, 11, 1223-1237. [PubMed: 27712124]

21. Kulkarni AR; Garai S; Janero DR; Thakur GA, Chapter Thirteen - Design and Synthesis of Cannabinoid 1 Receptor (CB1R) Allosteric Modulators: Drug Discovery Applications In Methods in Enzymology, Reggio PH, Ed. Academic Press2017; Vol. 593, pp 281-315. [PubMed: 28750808]

22. Ignatowska-Jankowska BM; Baillie GL; Kinsey S; Crowe M; Ghosh S; Owens RA; Damaj IM; Poklis J; Wiley JL; Zanda M; Zanato C; Greig IR; Lichtman AH; Ross RA, A Cannabinoid CB1 Receptor-Positive Allosteric Modulator Reduces Neuropathic Pain in the Mouse with No Psychoactive Effects. Neuropsychopharmacology 2015, 40, 29482959.

23. Tseng C-C; Baillie G; Donvito G; Mustafa MA; Juola SE; Zanato C; Massarenti C; Dall'Angelo S; Harrison WTA; Lichtman AH; Ross RA; Zanda M; Greig IR, The Trifluoromethyl Group as a Bioisosteric Replacement of the Aliphatic Nitro Group in CB1 Receptor Positive Allosteric Modulators. J. Med. Chem 2019, 62, 5049-5062. [PubMed: 31050898]

24. Pamplona FA; Ferreira J; Menezes de Lima O Jr.; Duarte FS; Bento AF; Forner S; Villarinho JG; Bellocchio L; Wotjak CT; Lerner R; Monory K; Lutz B; Canetti C; Matias I; Calixto JB; Marsicano G; Guimaraes MZ; Takahashi RN, Anti-inflammatory Lipoxin A4 is an Endogenous Allosteric Enhancer of CB1 Cannabinoid Receptor. Proc. Natl. Acad. Sci. U.S.A. 2012, 109, 21134-21139. [PubMed: 23150578]

25. Laprairie RB; Kulkarni PM; Deschamps JR; Kelly MEM; Janero DR; Cascio MG; Stevenson LA; Pertwee RG; Kenakin TP; Denovan-Wright EM; Thakur GA, Enantiospecific Allosteric Modulation of Cannabinoid 1 Receptor. ACS Chem. Neurosci 2017, 8, 1188-1203. [PubMed: 28103441] 
26. Mitjavila J; Yin D; Kulkarni PM; Zanato C; Thakur GA; Ross R; Greig I; Mackie K; Straiker A, Enantiomer-Specific Positive Allosteric Modulation of CB1 Signaling in Autaptic Hippocampal Neurons. Pharmacol. Res 2018, 129, 475-481. [PubMed: 29158048]

27. Slivicki RA; Xu Z; Kulkarni PM; Pertwee RG; Mackie K; Thakur GA; Hohmann AG, Positive Allosteric Modulation of Cannabinoid Receptor Type 1 Suppresses Pathological Pain Without Producing Tolerance or Dependence. Biol. Psychiatry 2018, 84, 722-733. [PubMed: 28823711]

28. Cairns EA; Szczesniak A-M; Straiker AJ; Kulkarni PM; Pertwee RG; Thakur GA; Baldridge WH; Kelly MEM, The In Vivo Effects of the CB1-Positive Allosteric Modulator GAT229 on Intraocular Pressure in Ocular Normotensive and Hypertensive Mice. J. Ocul. Pharmacol. Ther 2017, 33, 582590. [PubMed: 28719234]

29. Laprairie RB; Bagher AM; Rourke JL; Zrein A; Cairns EA; Kelly MEM; Sinal CJ; Kulkarni PM; Thakur GA; Denovan-Wright EM, Positive Allosteric Modulation of the Type 1 Cannabinoid Receptor Reduces the Signs and Symptoms of Huntington's Disease in the R6/2 Mouse Model. Neuropharmacology 2019, 151, 1-12. [PubMed: 30940536]

30. Conn PJ; Kuduk SD; Doller D, Drug Design Strategies for GPCR Allosteric Modulators. Annu. Rep. Med. Chem 2012, 47, 441-457. [PubMed: 26962268]

31. Berninger M; Erk C; Fuß A; Skaf J; Al-Momani E; Israel I; Raschig M; Güntzel P; Samnick S; Holzgrabe U, Fluorine walk: The Impact of Fluorine in Quinolone Amides on their Activity Against African Sleeping Sickness. Eur. J. Med. Chem 2018, 152, 377-391. [PubMed: 29742443]

32. Meanwell NA, Fluorine and Fluorinated Motifs in the Design and Application of Bioisosteres for Drug Design. J. Med. Chem 2018, 61, 5822-5880. [PubMed: 29400967]

33. Gillis EP; Eastman KJ; Hill MD; Donnelly DJ; Meanwell NA, Applications of Fluorine in Medicinal Chemistry. J. Med. Chem 2015, 58, 8315-8359. [PubMed: 26200936]

34. Pennington LD; Moustakas DT, The Necessary Nitrogen Atom: A Versatile High-Impact Design Element for Multiparameter Optimization. J. Med. Chem 2017, 60, 3552-3579. [PubMed: 28177632]

35. Lindsley CW; Emmitte KA; Hopkins CR; Bridges TM; Gregory KJ; Niswender CM; Conn PJ, Practical Strategies and Concepts in GPCR Allosteric Modulator Discovery: Recent Advances with Metabotropic Glutamate Receptors. Chem. Rev 2016, 116, 6707-6741. [PubMed: 26882314]

36. Scully SS; Tang AJ; Lundh M; Mosher CM; Perkins KM; Wagner BK, SmallMolecule Inhibitors of Cytokine-Mediated STAT1 Signal Transduction in $\beta$-Cells with Improved Aqueous Solubility. J. Med. Chem 2013, 56, 4125-4129. [PubMed: 23617753]

37. Worrall DE, Nitrostyrene. Org. Synth 1929, 9, 66.

38. Kulkarni PM; Ranade A; Garai S; Thakur GA, Microwave-accelerated Conjugate Addition of 2Arylindoles to Substituted $\beta$-Nitrostyrenes in the Presence of Ammonium Trifluoroacetate: An Efficient Approach for the Synthesis of a Novel Class of CB1 Cannabinoid Receptor Allosteric Modulators. J. Het. Chem 2017, 54, 2079-2084.

39. Yang S-D; Sun C-L; Fang Z; Li B-J; Li Y-Z; Shi Z-J, Palladium-Catalyzed Direct Arylation of (Hetero)Arenes with Aryl Boronic Acids. Angew. Chem. Int. Ed 2008, 47, 14731476.

40. Lopchuk JM; Gribble GW, A Convenient 1,3-Dipolar Cycloaddition Approach to Pyridylpyrroles. Tetrahedron Lett. 2011, 52, 4106-4108.

41. Thakur G, Kulkarni A, Pushkar M, Allosteric Modulators of CB1 Cannabinoid Receptors. US 10246414 B 22013.

42. Aslanian RG Berlin MY; Mangia-Racina P; MC Cormick KD; Mutahi MW; Rosenblum SB, Indole Derivatives Useful as Histamine H3 Antagonists. WO 2004/000831 2004, A1.

43. Song JJ; Tan Z; Gallou F; Xu J; Yee NK; Senanayake CH, A Novel One-Step Synthesis of 2Substituted 6-Azaindoles from 3-Amino-4-picoline and Carboxylic Esters. The J. Org. Chem 2005, 70, 6512-6514. [PubMed: 16050720]

44. Gilmore K; Alabugin IV, Cyclizations of Alkynes: Revisiting Baldwin's Rules for Ring Closure. Chem. Rev 2011, 111, 6513-6556. [PubMed: 21861478]

45. Lu X; Petersen JL; Wang KK, Synthesis of Novel Heteroaromatics Structurally Related to Ellipticine Alkaloids via Thermolysis of Pyridannulated Enyne-Carbodiimides. J. Org. Chem 2002, 67, 5412-5415. [PubMed: 12126441] 
46. Jose G; Suresha Kumara TH; Nagendrappa G; Sowmya HBV; Jasinski JP; Millikan SP; More SS; Janardhan B; Harish BG; Chandrika N, Synthesis, Crystal Structure, Molecular Docking and Antimicrobial Evaluation of New Pyrrolo[3,2-c]pyridine Derivatives. J. Mol. Struct 2015, 1081, 85-95.

47. Noland WE; Christensen GM; Sauer GL; Dutton GGS, The Reaction of Nitroölefins with Indole. J. Am. Chem. Soc 1955, 77, 456-457.

48. Kuster George J. T.; Steeghs Ruud H. J.; Scheeren Hans W., Novel Five/Five- and Six/ FiveMembered Bicyclic Nitroso Acetals from High-Pressure-Promoted Cyclisation Reactions of pMethoxybenzyl Vinyl Ether, 1-Nitro-2-heteroaryl Ethenes, and Mono- and Di-Substituted Olefins. Eur. J. Org. Chem 2001, 2001, 553-560.

49. Porter CJ; Trevaskis NL; Charman WN, Lipids and Lipid-based Formulations: Optimizing the Oral Delivery of Lipophilic Drugs. Nat. Rev. Drug. Discov 2007, 6, 231-48. [PubMed: 17330072]

50. Kenakin T, A Scale of Agonism and Allosteric Modulation for Assessment of Selectivity, Bias, and Receptor Mutation. Mol. Pharmacol 2017, 92, 414-424. [PubMed: 28679508]

51. Straiker A; Mackie K, Depolarization-induced Suppression of Excitation in Murine Autaptic Hippocampal Neurones. J. Physiol 2005, 569, 501-517. [PubMed: 16179366]

52. Cairns EA; Baldridge WH; Kelly MEM, The Endocannabinoid System as a Therapeutic Target in Glaucoma. Neural Plast 2016, 2016, Article ID 9364091, 10 pages.

53. Caldwell MD; Hu SSJ; Viswanathan S; Bradshaw H; Kelly MEM; Straiker A, A GPR18-based Signalling System Regulates IOP in Murine Eye. Br. J. Pharmacol 2013, 169, 834-843. [PubMed: 23461720]

54. Hudson BD; Beazley M; Szczesniak AM; Straiker A; Kelly MEM, Indirect Sympatholytic Actions at beta-Adrenoceptors Account for the Ocular Hypotensive Actions of Cannabinoid Receptor Agonists. J. Pharm. Exp. Ther 2011, 339, 757-767.

55. Chen J; Matias I; Dinh T; Lu T; Venezia S; Nieves A; Woodward DF; Di Marzo V, Finding of Endocannabinoids in Human Eye Tissues: Implications for Glaucoma. Biochem. Biophys. Res. Commun 2005, 330, 1062-1067. [PubMed: 15823551]

56. Nucci C; Bari M; Spano A; Corasaniti M; Bagetta G; Maccarrone M; Morrone LA, Potential Roles of (Endo)Cannabinoids in the Treatment of Glaucoma: from Intraocular Pressure Control to Neuroprotection. Glaucoma: An Open Window to Neurodegeneration and Neuroprotection 2008, 173, 451-464.

57. Cairns Elizabeth A; Toguri JT; Porter Richard F; Szczesniak A-M; Kelly Melanie EM, Seeing over the Horizon - Targeting the Endocannabinoid System for the Treatment of Ocular Disease. J. Basic Clin. Physiol. Pharmacol 2016, 27, 253-265. [PubMed: 26565550]

58. Li AL; Carey LM; Mackie K; Hohmann AG, Cannabinoid CB2 Agonist GW405833 Suppresses Inflammatory and Neuropathic Pain through a CB1 Mechanism that is Independent of CB2 Receptors in Mice. J. Pharmacol. Exp. Ther 2017, 362, 296-305. [PubMed: 28592614]

59. Li AL; Lin X; Dhopeshwarkar AS; Thomaz AC; Carey LM; Liu Y; Nikas SP; Makriyannis A; Mackie K; Hohmann AG, Cannabinoid CB2 Agonist AM1710 Differentially Suppresses Distinct Pathological Pain States and Attenuates Morphine Tolerance and Withdrawal. Mol. Pharmacol 2019, 95, 155-168. [PubMed: 30504240]

60. Slivicki RA; Xu Z; Kulkarni PM; Pertwee RG; Mackie K; Thakur GA; Hohmann AG, Positive Allosteric Modulation of Cannabinoid Receptor Type 1 Suppresses Pathological Pain Without Producing Tolerance or Dependence. Biol. Psychiatry 2018, 84, 722-733. [PubMed: 28823711]

61. Hurst DP; Garai S; Kulkarni PM; Schaffer PC; Reggio PH; Thakur GA, Identification of CB1 Receptor Allosteric Sites Using Force-Biased MMC Simulated Annealing and Validation by SAR Studies. ACS Med. Chem. Lett 2019, 10, 1216-1221. [PubMed: 31413808]

62. Bekkers JM; Stevens CF, Excitatory and Inhibitory Autaptic Currents in Isolated Hippocampal Neurons Maintained in Cell Culture. Proc. Natl. Acad. Sci. U. S. A 1991, 88, 7834-7838. [PubMed: 1679238]

63. Furshpan EJ; MacLeish PR; O’Lague PH; Potter DD, Chemical Transmission between Rat Sympathetic Neurons and Cardiac Myocytes Developing in Microcultures: Evidence for Cholinergic, Adrenergic, and Dual-function Neurons. Proc. Natl. Acad. Sci. U. S. A 1976, 73, 4225-4229. [PubMed: 186792] 
64. Levison SW; McCarthy KD, Characterization and Partial Purification of AIM: a Plasma Protein that Induces Rat Cerebral Type 2 Astroglia from Bipotential Glial Progenitors. J. Neurochem 1991, 57, 782-794. [PubMed: 1861150]

65. Tao Q; Abood ME, Mutation of a Highly Conserved Aspartate Residue in the Second Transmembrane Domain of the Cannabinoid Receptors, CB1 and CB2, Disrupts G-Protein Coupling. J. Pharmacol. Exp. Ther 1998, 285, 651-658. [PubMed: 9580609]

66. Grim TW; Morales AJ; Thomas BF; Wiley JL; Endres GW; Negus SS; Lichtman AH, Apparent CB(1) Receptor Rimonabant Affinity Estimates: Combination with THC and Synthetic Cannabinoids in the Mouse In Vivo Triad Model. J. Pharmacol. Exp. Ther 2017, 362, 210-218. [PubMed: 28442584]

67. Kilkenny C; Browne WJ; Cuthill IC; Emerson M; Altman DG, Improving Bioscience Research Reporting: The ARRIVE Guidelines for Reporting Animal Research. PLOS Biology 2010, 8, e1000412. [PubMed: 20613859]

68. Lin X; Dhopeshwarkar AS; Huibregtse M; Mackie K; Hohmann AG, Slowly Signaling G ProteinBiased CB2 Cannabinoid Receptor Agonist LY2828360 Suppresses Neuropathic Pain with Sustained Efficacy and Attenuates Morphine Tolerance and Dependence. Mol. Pharmacol 2018, 93, 49-62. [PubMed: 29192123]

69. Stahl EL; Zhou L; Ehlert FJ; Bohn LM, A Novel Method for Analyzing Extremely Biased Agonism at G Protein-Coupled Receptors. Mol. Pharmacol 2015, 87, 866-877. [PubMed: 25680753]

70. Black JW; Leff P, Operational Models of Pharmacological Agonism. Proc. R. Soc. Ser. Lond. B 1983, 220, 141-162. [PubMed: 6141562]

71. Kenakin T; Watson C; Muniz-Medina V; Christopoulos A; Novick S, A Simple Method for Quantifying Functional Selectivity and Agonist Bias. ACS Chem. Neurosci 2012, 3, 193-203. [PubMed: 22860188] 
<smiles>CCc1c(C(=O)NCCc2ccc(N3CCCCC3)cc2)[nH]c2ccc(Cl)cc12</smiles>

Org27569<smiles>CCCCC[C@H](O)/C=C\C=C/CC[C@@H](O)[C@@H](O)CCCC(=O)O</smiles>

Lipoxin A4<smiles>O=C(Nc1ccc(Cl)cc1)Nc1cccc(-c2cccc(N3CCCC3)n2)c1</smiles>

PSNCBAM-1<smiles>O=[N+]([O-])CC(c1ccccc1)c1c(-c2ccccc2)[nH]c2ccccc12</smiles>

GAT228

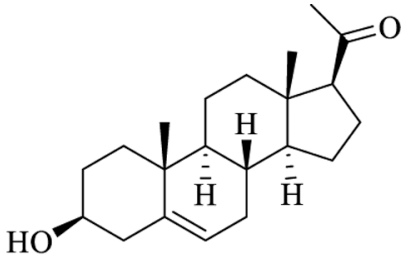

Pregnenolone

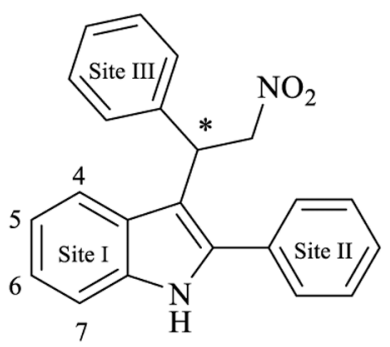

GAT211

Figure 1.

Structure of representative CB1 allosteric modulators 


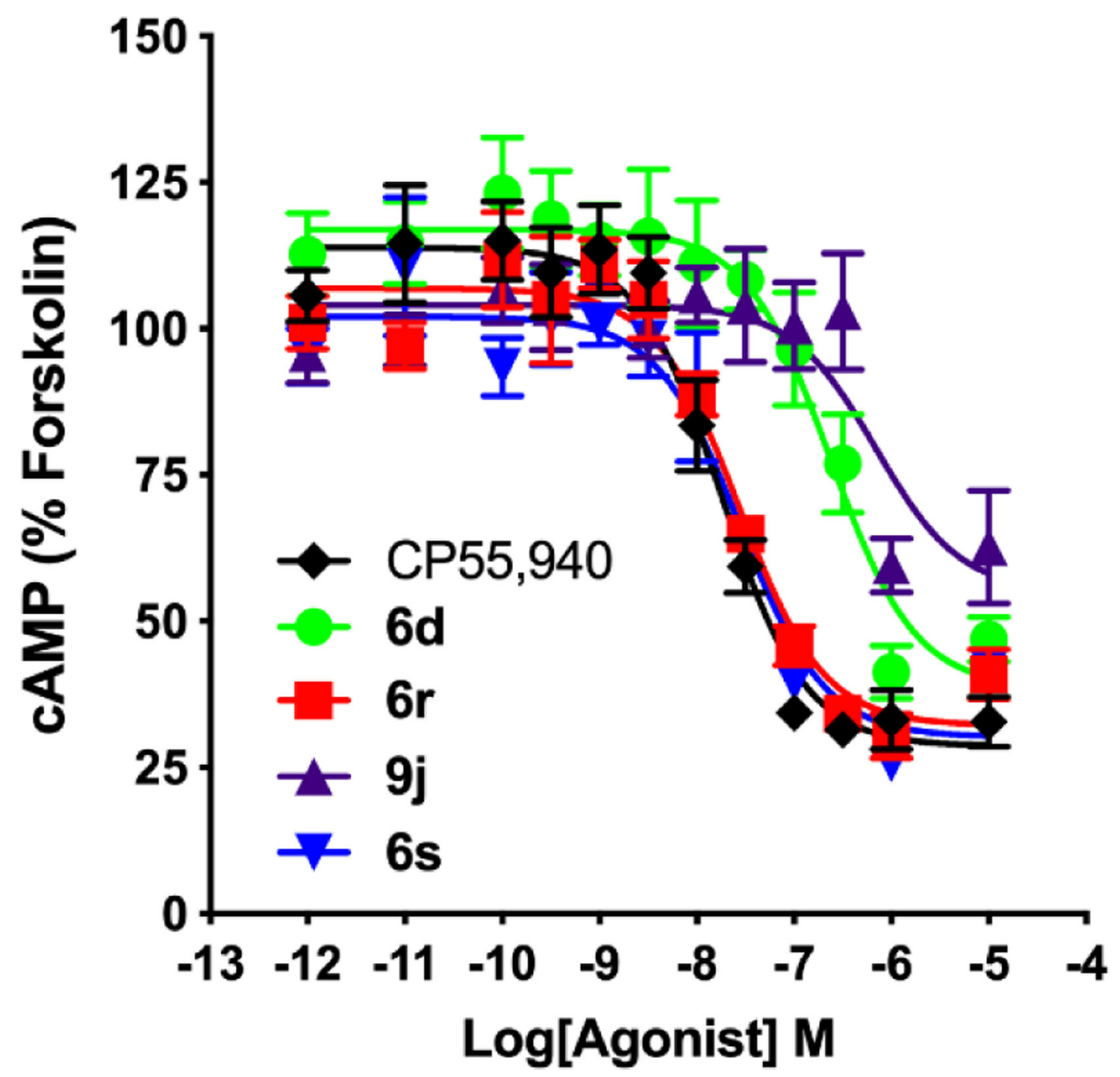

Figure 2.

Agonist effect of cAMP inhibition for $\mathbf{6 r}, \mathbf{9 j}$, and $\mathbf{6 s}$. HEK293 cells stably-expressing GFPrCB1R were treated with $1 \mathrm{pM}-10 \mu \mathrm{M}$ key compounds alone for $30 \mathrm{~min}$ in the presence of $5 \mu \mathrm{M}$ Forskolin and cAMP inhibition was measured. Data are expressed as \% Forskolin response and were fit to a nonlinear regression (4 parameter model, GraphPad v. 7) for statistics in Table 4. Data are mean \pm S.E.M., $n \geq 3$ independent experiments performed in triplicate. 


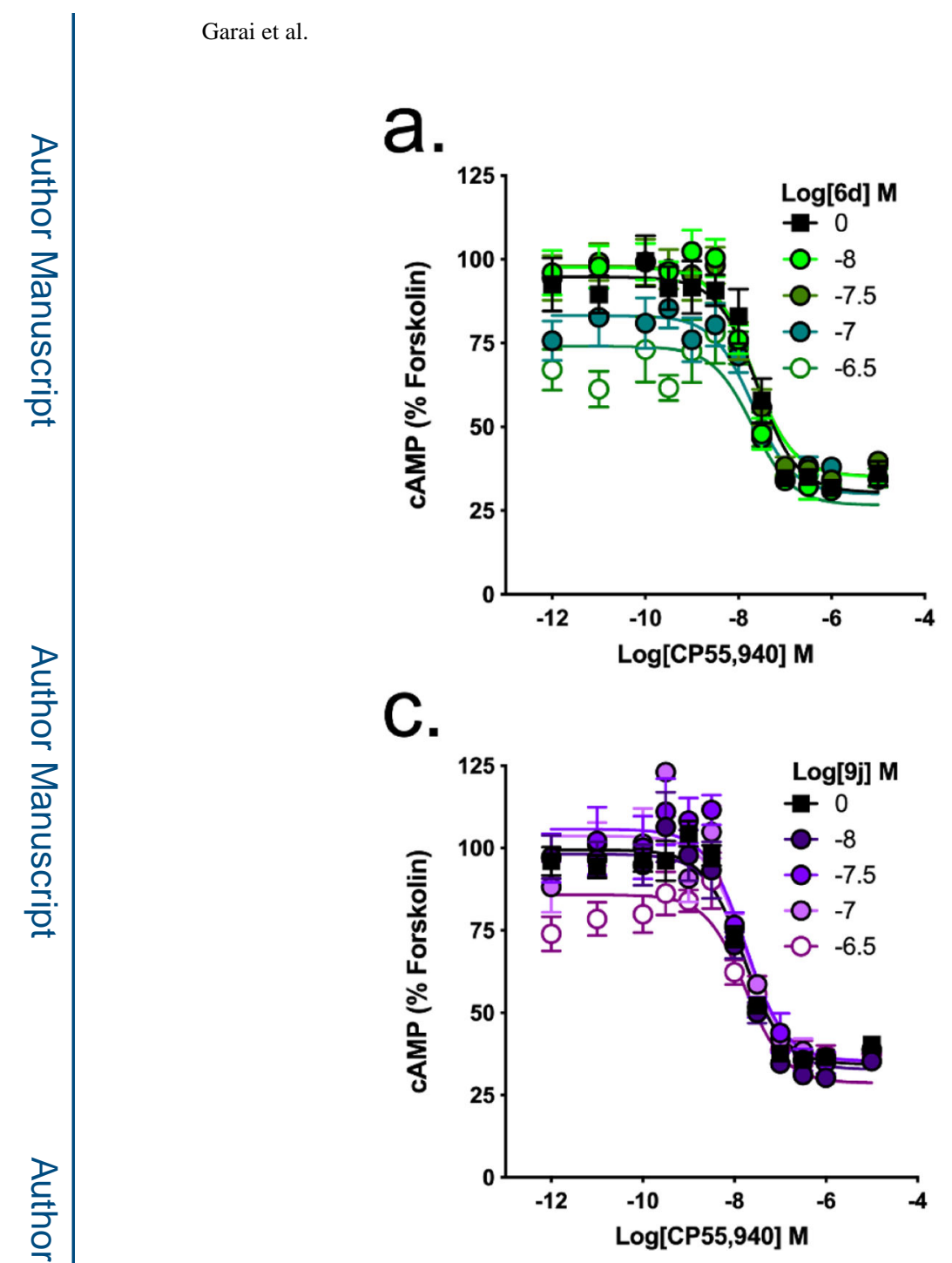

\section{b.}

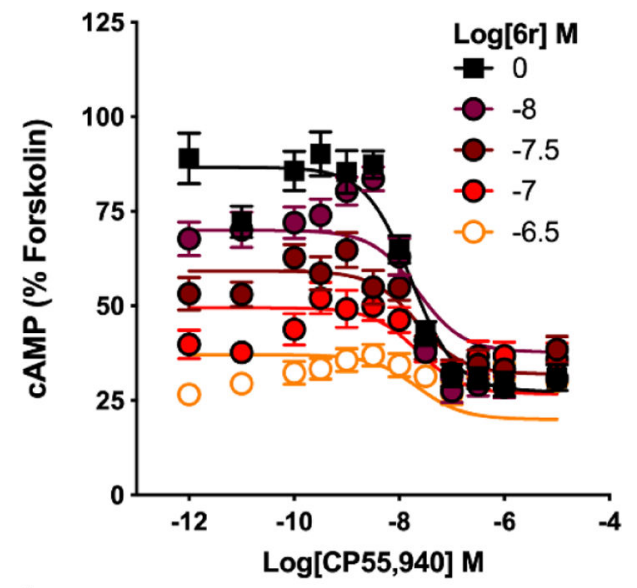

d.

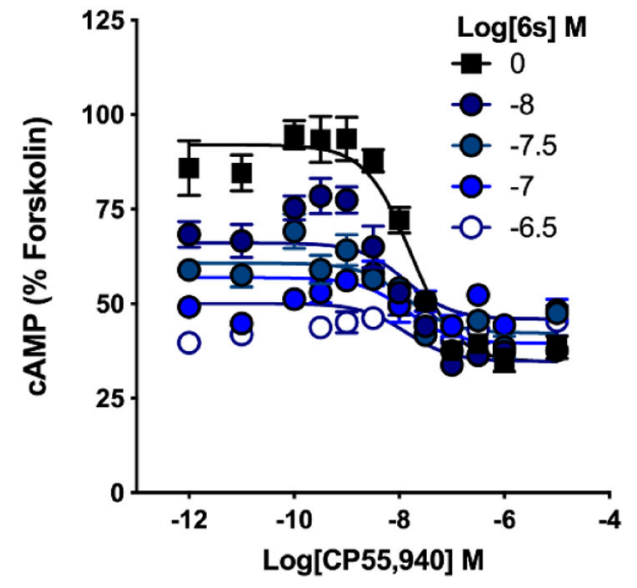

Figure 3.

Positive allosteric modulation of cAMP inhibition for $\mathbf{6 r}, \mathbf{9 j}$, and $\mathbf{6 s}$. HEK293 cells stablyexpressing GFP-rCB1R were treated with $1 \mathrm{pM}-10 \mu \mathrm{M}$ CP55,940 and 10, 30, 100, or 300 nM GAT compounds alone for $30 \mathrm{~min}$ in the presence of $5 \mu \mathrm{M}$ Forskolin and cAMP inhibition was measured. Data are expressed as \% Forskolin response and were fit to a nonlinear regression (4 parameter model, GraphPad v. 7) for statistics in Table 4. Data are mean \pm S.E.M., $n \geq 3$ independent experiments performed in triplicate. 
a.

C.

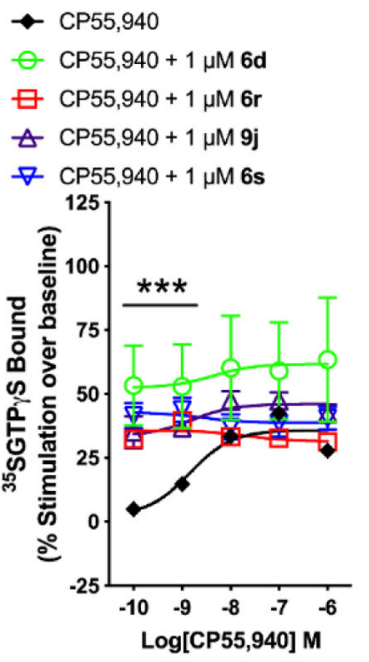

$$
7 \text { s } 5.2(1.0-46)
$$
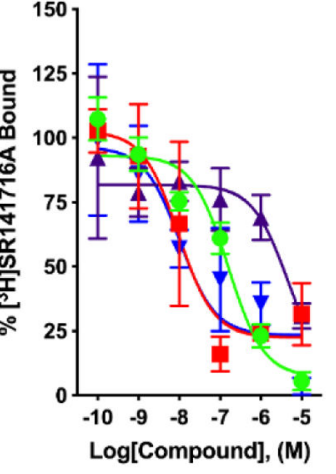

Figure 4. b.

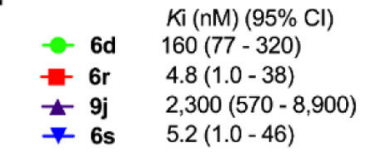

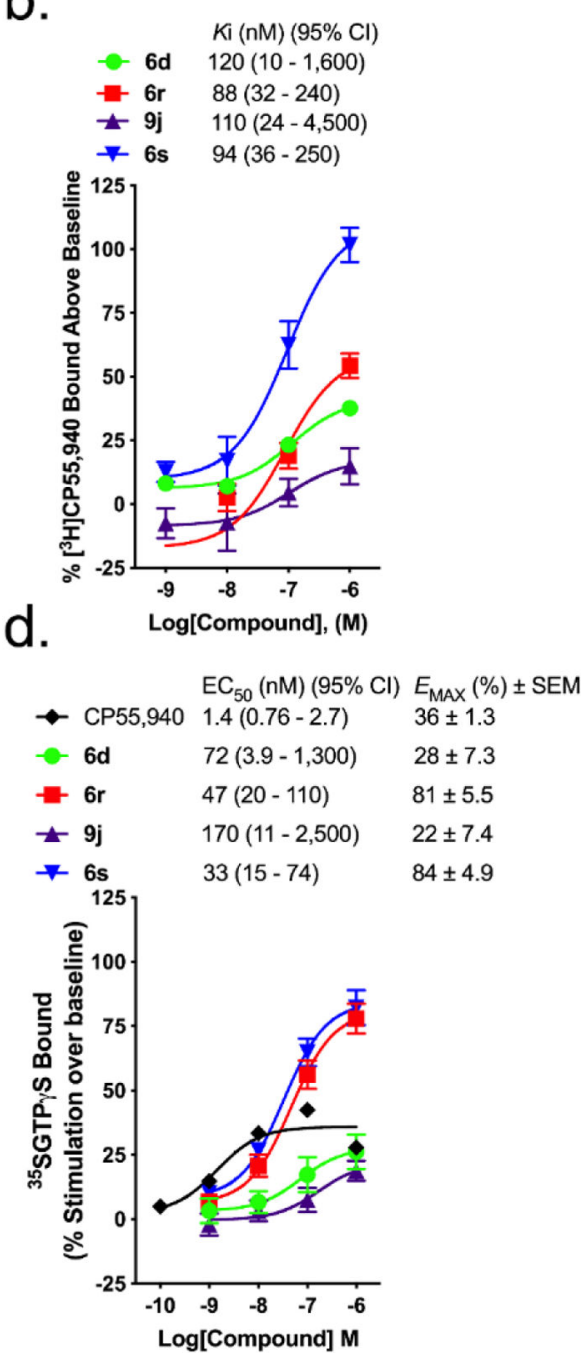

Effect of $\mathbf{6 r}, \mathbf{9 j}$, and $\mathbf{6 s}$ on the binding of a) $1 \mathrm{nM}[3 \mathrm{H}] \mathrm{SR} 141716 \mathrm{~A}$ or b) $[3 \mathrm{H}] \mathrm{CP} 55,940$ to membranes obtained from $\mathrm{CHO}$ cells stably-expressing human $\mathrm{CB} 1 \mathrm{R}$; or the binding of [35S]GTP $\gamma \mathrm{S}$ to $\mathrm{G}$ protein in membranes obtained from $\mathrm{CHO}$ cells stably-expressing human CB1R and treated with c) CP55,940 and $1 \mu \mathrm{M}$ GAT compound, or d) GAT compound alone. $K 1(\mathrm{nM})$ and EC50 (nM) are mean with 95\% CI. EMax data are mean \pm SEM. Data were fit to a variable slope (4 parameter) nonlinear regression model, mean \pm SEM, $n=4-6$ independent experiments performed in duplicate. $* * * P<0.001$ Student's one sample $t$-test. 


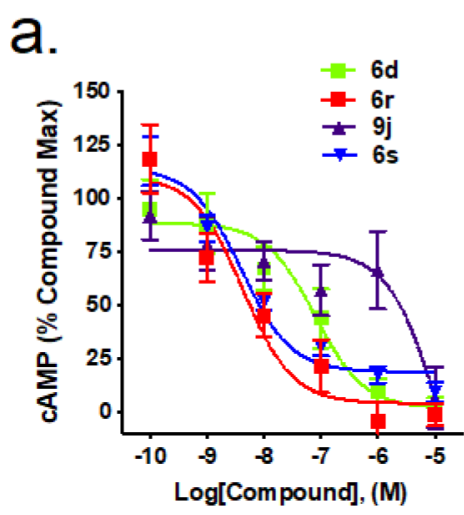

b.

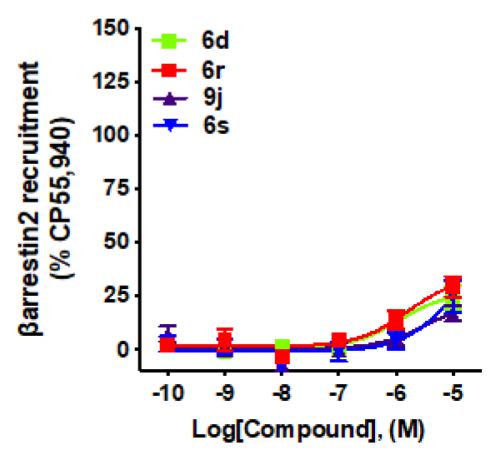

e.

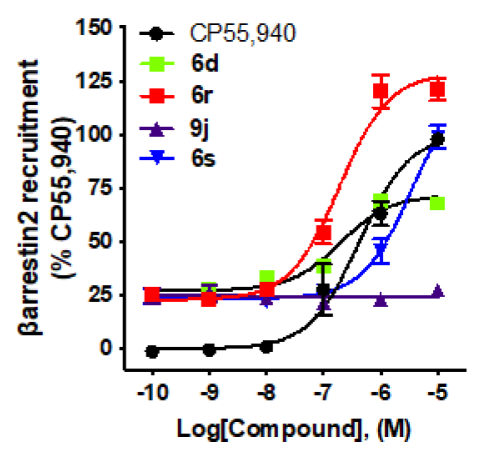

C.

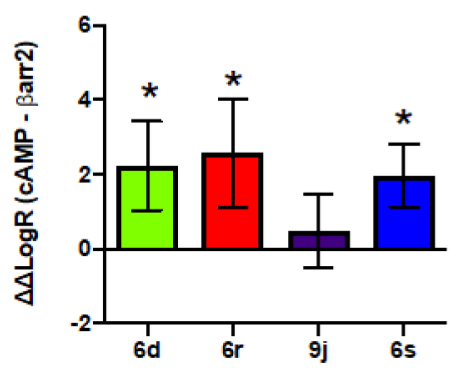

f.

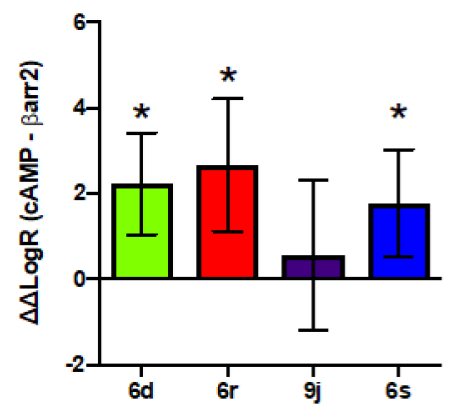

Figure 5.

(a-c) CHO cells stably-expressing hCB1R were treated with $0.10 \mathrm{nM}-10 \mu \mathrm{M}$ GAT compounds alone for 90 min and cAMP inhibition (a) or $\beta$ arrestin2 recruitment was measured (b). Compound agonist bias between cAMP inhibition and $\beta$ arrestin2 recruitment $(\Delta \Delta \operatorname{LogR}(\mathrm{cAMP}-\beta \operatorname{arr} 2)]$ is shown in c. (d-f) $\mathrm{CHO}$ cells stably-expressing hCB1R were treated with $100 \mathrm{nM}$ CP55,940 + $0.10 \mathrm{nM}-10 \mu \mathrm{M}$ GAT compounds for $90 \mathrm{~min}$ and cAMP inhibition (d) or $\beta$ arrestin2 recruitment was measured (e). Compound PAM bias between cAMP inhibition and $\beta$ arrestin2 recruitment $(\Delta \Delta \operatorname{LogR}$ (cAMP - $\beta$ arr2)] is shown in f. cAMP data are expressed as \% Forskolin response within compound treatment. $\beta$ arrestin2 recruitment data are expressed as \% CP55,940 response. Data were fit to a nonlinear regression (4 parameter model, GraphPad v. 7) for statistics in Table 5; or fit to the operational model (eq. 1) to calculate bias (c,f). Data are mean \pm S.E.M. or $95 \%$ CI (c,f), $n \geq$ 6 independent experiments performed in triplicate. 

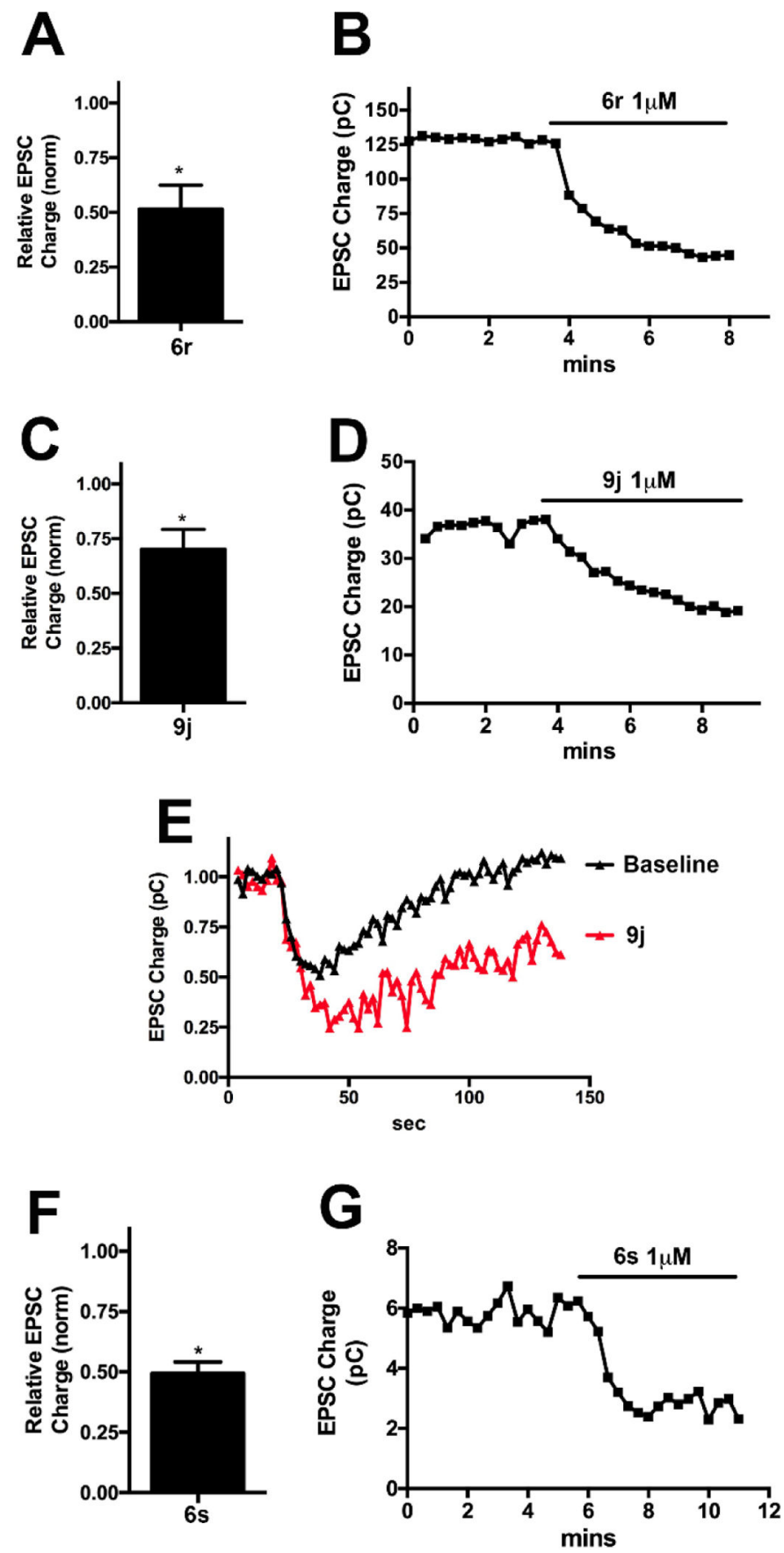

Figure 6.

Electrophysiology Studies on $\mathbf{6 r}, \mathbf{9 j}$ and $\mathbf{6 s}$. A) Averaged direct inhibition of EPSCs upon $1 \mu \mathrm{M}$ 6r application. B) Sample time course showing inhibition of EPSCs upon treatment with 6r. C) Averaged direct inhibition of EPSCs upon $1 \mu \mathrm{M}$ 9j application. D) Sample time course showing inhibition of EPSCs upon treatment with 9j. E) Sample DSE time course from a cell showing an enhanced DSE response after $\mathbf{9 j}$ treatment, consistent with a PAMlike response. F) Averaged direct inhibition of EPSCs upon $1 \mu \mathrm{M}$ 6s application. G) Sample time course showing inhibition of EPSCs upon treatment with $\mathbf{6 s}$. 


\section{(A)}

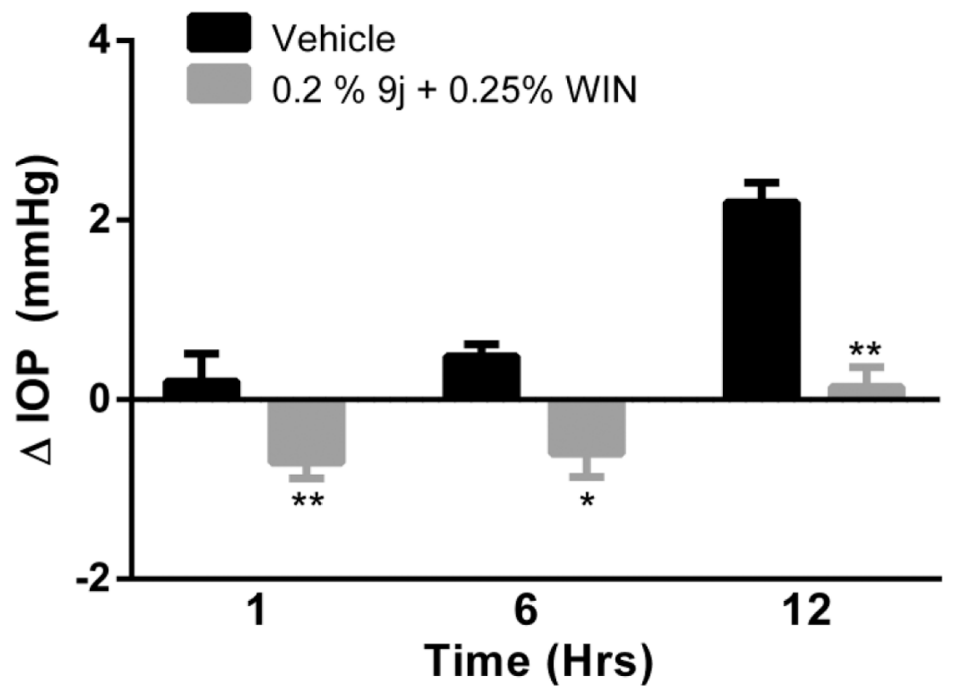

(B)

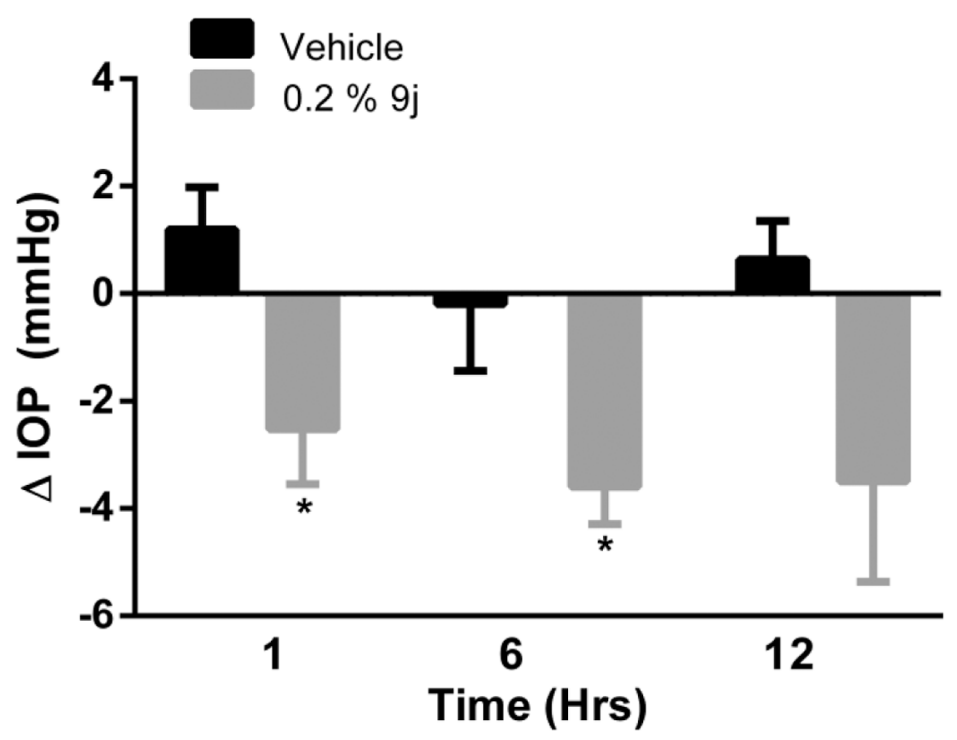

Figure 7:

Effects of topical administration of PAM 9j on IOP. A) Acute treatment with $9 \mathrm{j}(0.2 \%)$ potentiates the IOP lowering effect of WIN $(0.25 \%)$ in normotensive mice $(n=5)$ at 1,6 and $12 \mathrm{hrs}$ after administration. B) $9 \mathrm{j}(0.2 \%)$ significantly decreased IOP in ocular hypertensive NEE mice at 1 and 6 hrs after administration $(n=6)$. Values are represented as a change in IOP (means \pm SEM) from the baseline (time 0). Paired t-tests, $\mathrm{P}<0.05$. 
Ipsilateral Paw

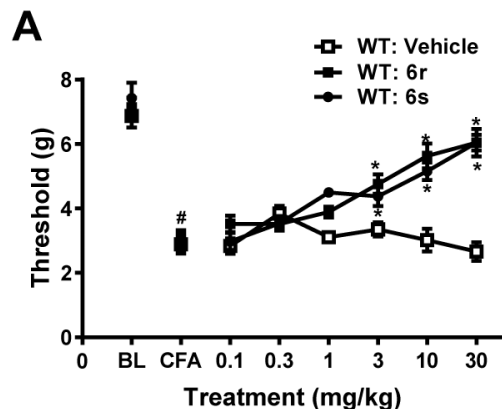

C

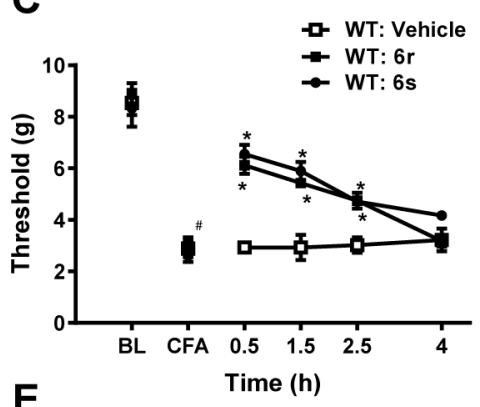

E

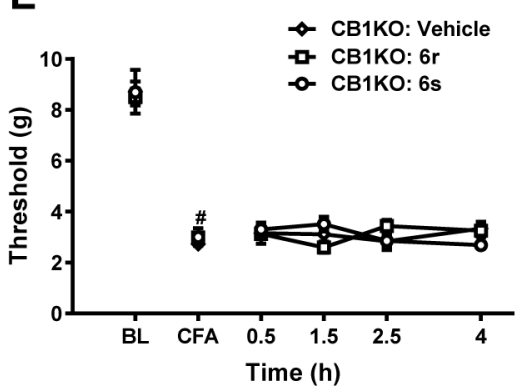

Contralateral Paw

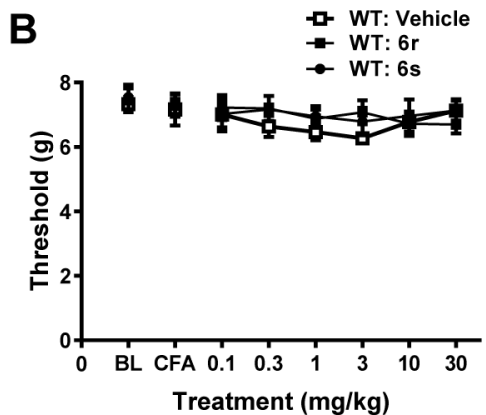

D

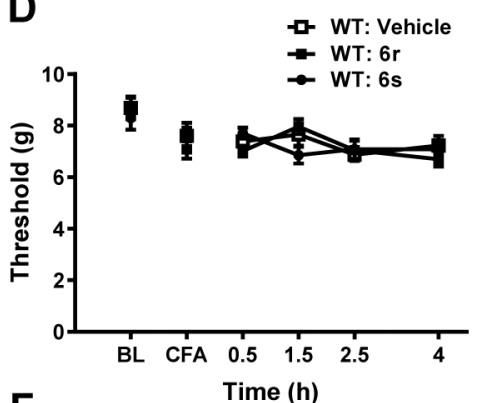

$\mathbf{F}$

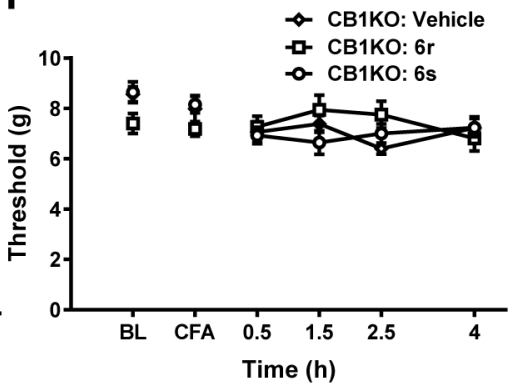

Figure 8:

The $\mathrm{CB} 1$ positive allosteric modulators $6 \mathrm{r}$ and $6 \mathrm{~s}$ suppress CFA-Induced mechanical allodynia. (A, B) Both $\mathbf{6 r}(0.1,0.3,1,3,10$ and $30 \mathrm{mg} / \mathrm{kg}$ i.p.) and $\mathbf{6 s}(0.1,0.3,1,3,10$ and $30 \mathrm{mg} / \mathrm{kg}$ i.p.) increase mechanical paw withdrawal thresholds in the paw ipsilateral (A) but not contralateral (B) to CFA injection. (C, D) Both 6r (30 mg/kg i.p.) and $6 \mathbf{s}(30 \mathrm{mg} / \mathrm{kg}$ i.p.) elevated mechanical paw withdrawal thresholds in the paw ipsilateral (C) but not contralateral (D) to CFA injection with efficacy observed over at least $2.5 \mathrm{~h}$ post injection. (E, F) Neither $\mathbf{6 r}$ nor $\mathbf{6 s}$ altered mechanical paw withdrawal thresholds in CB1 KO mice in the paw ipsilateral (E) or contralateral (F) to CFA injection. 

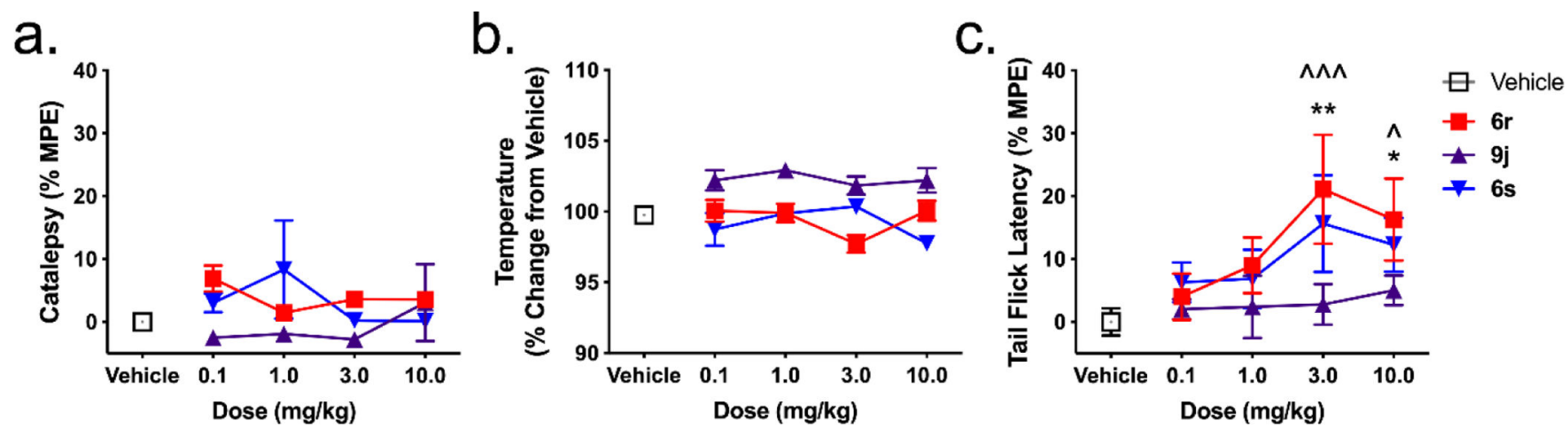

Figure 9.

Effect of key CB1R ago-PAMs on catalepsy, hypothermia and tail flick test. Male C57BL/6 mice treated with $0.1-10 \mathrm{mg} / \mathrm{kg}$ compound or vehicle (1:1:18 ethanol:cremaphor:saline) and physiological assessments of catalepsy ( $5 \mathrm{~min}, \%$ MPE $60 \mathrm{sec}$ ) (a), body temperature relative to vehicle $(15 \mathrm{~min}, 100 \%)(\mathbf{b})$, and nociception in the tail flick assay $\left(52^{\circ} \mathrm{C}\right)(20 \mathrm{~min}$, $\%$ MPE $20 \mathrm{sec})(\mathbf{c}) . \mathrm{n}=5-6$, data are mean \pm SEM. $* P<0.05, * * P<0.01$ 6r compared to vehicle; ${ }^{\wedge} P<0.05, \wedge \wedge \wedge P<0.0016$ s compared to vehicle as determined via two-way ANOVA followed by Tukey's post-hoc test. 


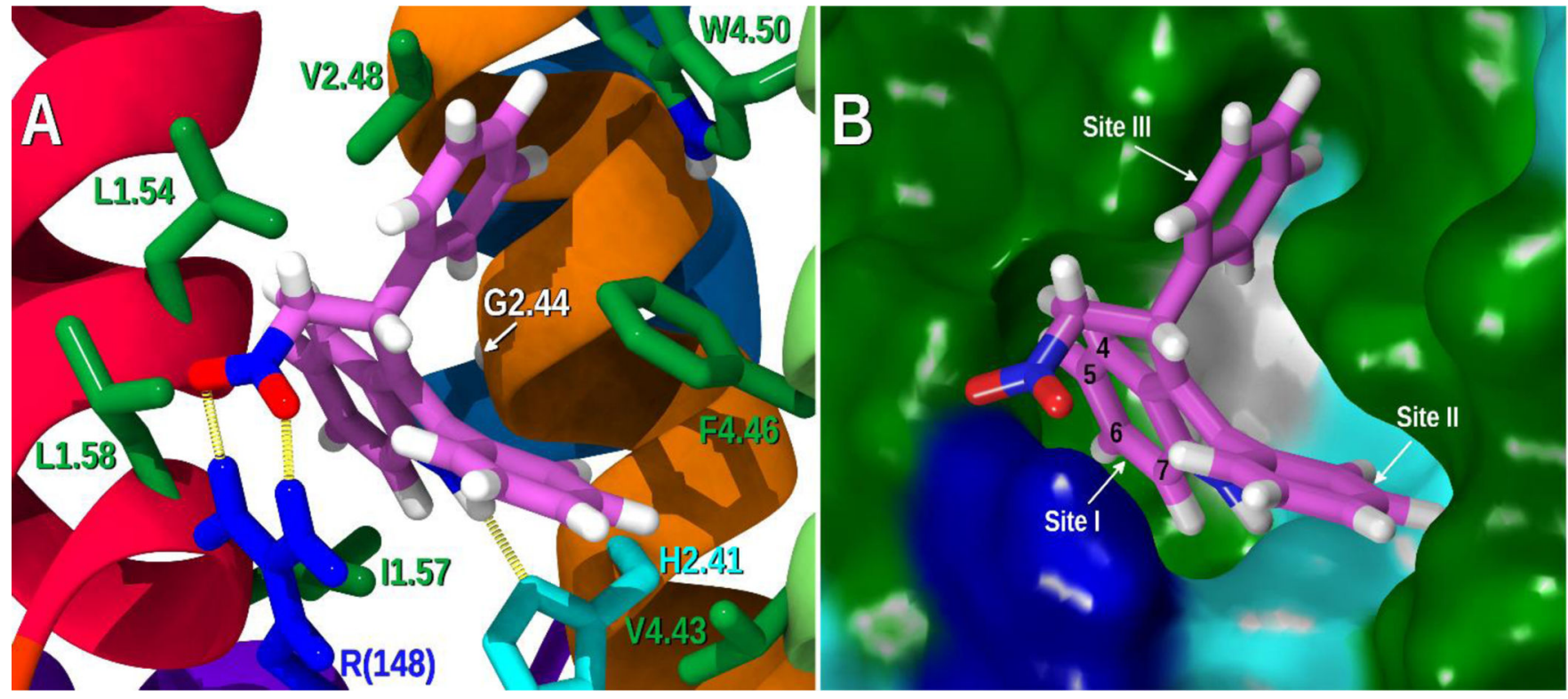

Figure 10.

A) The GAT228 binding site. The indole, Site I, is deeply inserted into a hydrophobic pocket made up of L1.54, I1.57, L1.58, and G2.44; PDB-ID: 6N4B, B) The GAT228 binding site is rendered here in a Connolly surface with residues colored green if hydrophobic, cyan if polar, dark blue if positively charged, red if negatively charged, and gray if a glycine. Site I, II, III labels correspond to GAT211 labels shown in Figure 1. Indole atom positions 4-7 are labeled to help the reader understand the SAR discussion. The viewpoint is the same as in panel A. 


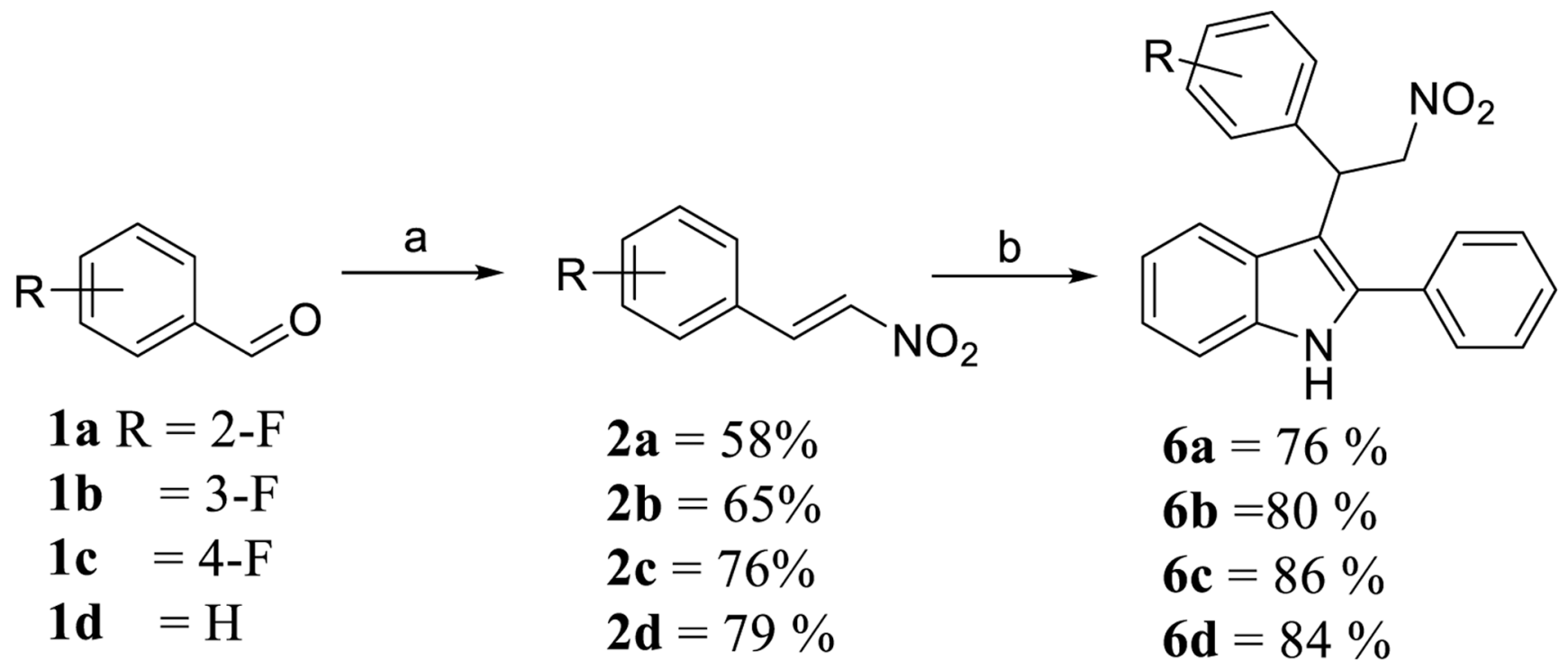

Reagents and Conditions: a) i) $\mathrm{CH}_{3} \mathrm{NO}_{2}, \mathrm{NaOH}$; $10-15{ }^{0} \mathrm{C}, 5-10 \mathrm{~min}$ ii) $10 \%$ $\mathrm{HCl}, 0{ }^{\circ} \mathrm{C}$; b) 2-phenyl indole (5), $\mathrm{CF}_{3} \mathrm{COONH}_{4}, 25 \%$ aq. EtOH, MW, 10-20 min.

Scheme 1.

Synthesis of mono fluoro derivatives $\mathbf{6 a - 6 d}$. 

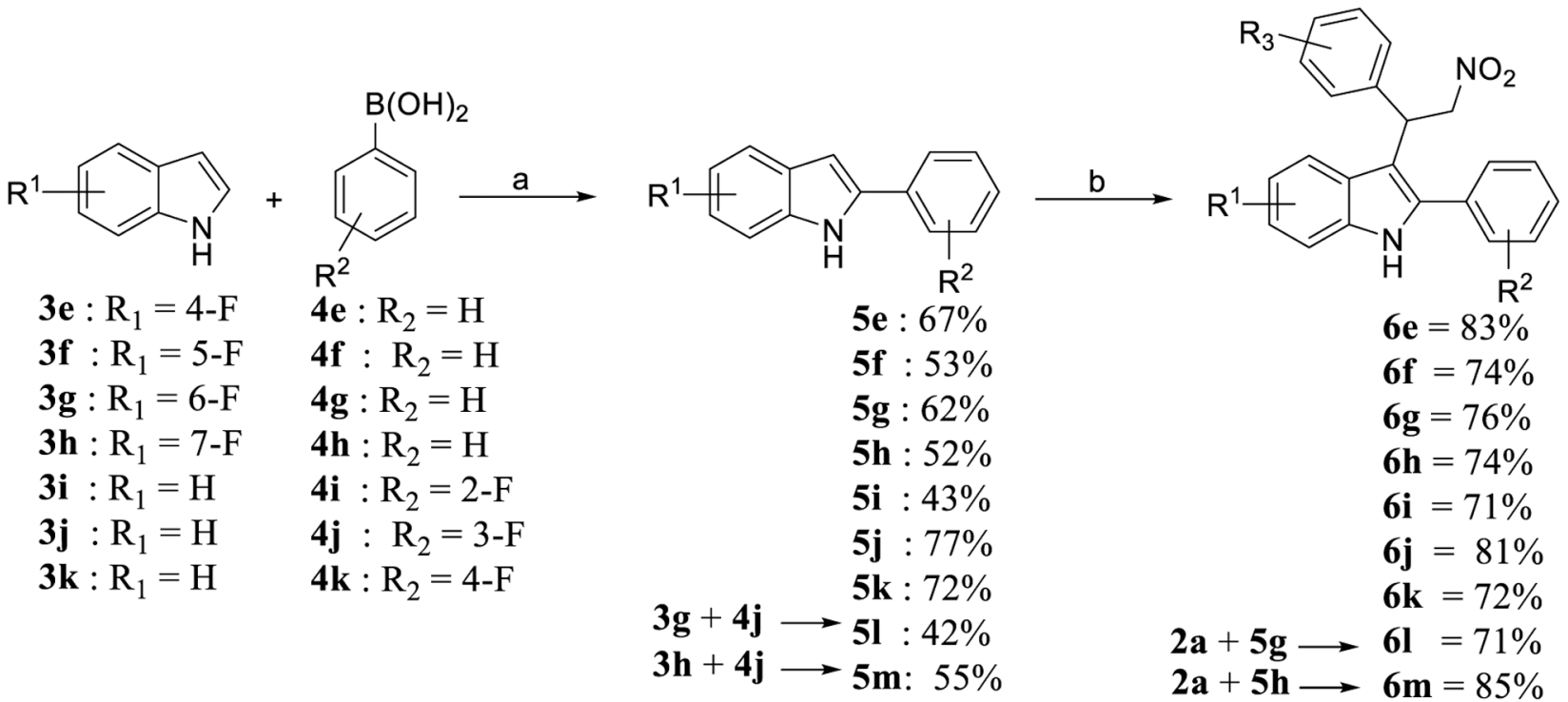

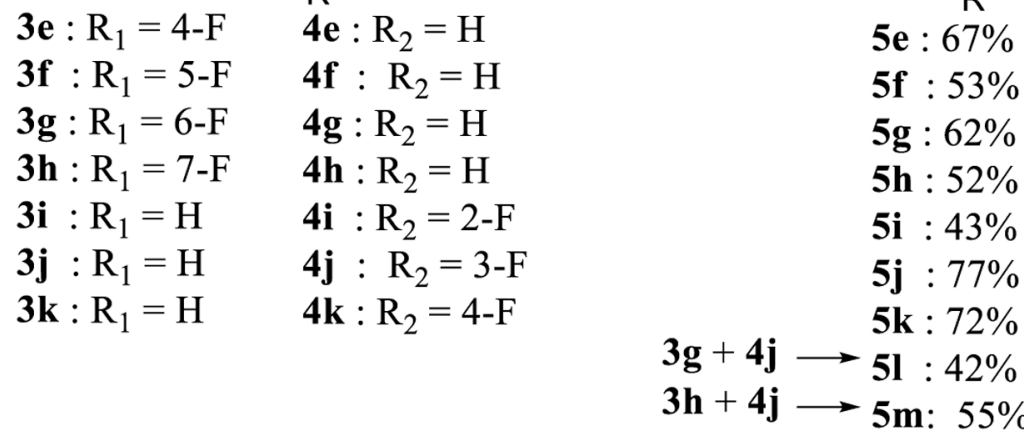

$\mathbf{6 e}=83 \%$

6f $=74 \%$

$\mathbf{6 g}=76 \%$

$\mathbf{6 h}=74 \%$

6i $=71 \%$

$\mathbf{6 j}=81 \%$

$\mathbf{6 k}=72 \%$

$\mathbf{2 a}+5 \mathbf{g} \longrightarrow \mathbf{6 1}=71 \%$

$2 \mathbf{a}+\mathbf{5 h} \longrightarrow 6 \mathbf{m}=85 \%$

$2 \mathrm{c}+5 \mathrm{~g} \longrightarrow 6 \mathrm{n}=65 \%$

$\mathbf{2 c}+\mathbf{5 h} \longrightarrow \mathbf{6 o}=51 \%$

$2 c+5 \mathbf{l} \longrightarrow 6 \mathbf{p}=63 \%$

$2 \mathrm{c}+5 \mathrm{~m} \longrightarrow \mathbf{6 q}=73 \%$

$2 \mathbf{a}+\mathbf{5 l} \longrightarrow \mathbf{6 r}=80 \%$

$2 \mathrm{a}+5 \mathrm{~m} \longrightarrow 6 \mathrm{~s}=83 \%$

Reagents and Conditions: a) $\mathrm{Pd}(\mathrm{OAc})_{2}, \mathrm{AcOH}, \mathrm{O}_{2}, \mathrm{rt}, 12-24 \mathrm{hrs}$; b) $\mathbf{2 a} / \mathbf{2 c} / \mathbf{2 d}, \mathrm{CF}_{3} \mathrm{COONH}_{4}, 25 \%$ aq. EtOH, $\mathrm{MW} /$ heat, $100-110{ }^{0} \mathrm{C}, 10 \mathrm{~min}-12 \mathrm{hrs}$.

Scheme 2.

Synthesis of mono, di- and tri- fluoro derivatives 6e-6q. 
<smiles></smiles>

$7 \mathbf{a} \mathrm{X}_{1}=\mathrm{N} ; \mathrm{X}_{2}=\mathrm{X}_{3}=\mathrm{CH}$

7b $\mathrm{X}_{2}=\mathrm{N} ; \mathrm{X}_{1}=\mathrm{X}_{3}=\mathrm{CH}$

7c $\mathrm{X}_{3}=\mathrm{N} ; \mathrm{X}_{1}=\mathrm{X}_{2}=\mathrm{CH}$<smiles>[Y][Y4]1:[Y4]c(/C=C/[N+](=O)[O-])cc1</smiles>

8a: $\left(a_{1}\right) 37 \%$

8b: $\left(a_{2}\right) 65 \%$

8c: $\left(a_{3}\right) 55 \%$<smiles>[Y4]C/C=C\C(C[N+](=O)[O-])c1c(-c2ccccc2)[nH]c2ccccc12</smiles>

9a: $58 \%$

9b: $40 \%$

9c: $27 \%$<smiles>C[Y4]1:[Y4]c(C(C)=O)cc1</smiles><smiles>[Y2][Y4]1ccc(-c2cc3ccccc3[nH]2)[Y](C)c1</smiles><smiles>[Y][Y4]1cc([Y4])ccc1-c1[nH]c2ccccc2c1C(C[N+](=O)[O-])c1ccccc1</smiles>

10a $\mathrm{X}_{1}=\mathrm{N} ; \mathrm{X}_{2}=\mathrm{X}_{3}=\mathrm{CH}$

$10 b \mathrm{X}_{2}=\mathrm{N} ; \mathrm{X}_{1}=\mathrm{X}_{3}=\mathrm{CH}$

10c $X_{3}=\mathrm{N} ; \mathrm{X}_{1}=\mathrm{X}_{2}=\mathrm{CH}$

11a: $34 \%$

11b: $73 \%$

11c: $68 \%$

9d $\mathrm{X}_{2}=\mathrm{N} ; \mathrm{X}_{1}=\mathrm{X}_{3}=\mathrm{CH} ; 68 \%$

9e $\mathrm{X}_{3}=\mathrm{N} ; \mathrm{X}_{1}=\mathrm{X}_{2}=\mathrm{CH} ; 54 \%$

Reagents and Conditions: $\mathrm{a}_{1}$ )(i) $\mathrm{CH}_{3} \mathrm{NO}_{2}$, TMG; (ii) $\mathrm{MsCl}$, triethylamine ${ }^{41}$; a ) (i) $\mathrm{CH}_{3} \mathrm{NO}_{2}, t \mathrm{BuOH}$, THF, tBuOK,(ii)DMAP, $\mathrm{Ac}_{2} \mathrm{O}, \mathrm{DCM}^{48}$; $\mathrm{a}_{3}$ )(i) $\mathrm{CH}_{3} \mathrm{NO}_{2}$, $\mathrm{K}_{2} \mathrm{CO}_{3}$; b) $\mathrm{Ac}_{2} \mathrm{O}, \mathrm{NaOAc}^{40}$; b) 5 , ${ }^{\mathrm{n}} \mathrm{Bu}_{4} \mathrm{NI}$, dioxane: water ( 9:1), reflux, 12 hrs; c) i) phenyl hydrazine, $\mathrm{C}_{2} \mathrm{H}_{5} \mathrm{OH}, 105{ }^{0} \mathrm{C}, 6 \mathrm{~h}$; ii) PPA, $\mathrm{C}_{2} \mathrm{H}_{5} \mathrm{OH}, 125{ }^{\circ} \mathrm{C}, 1 \mathrm{~h}$; d) $\beta$-nitrostyrene, $\mathrm{Et}_{4} \mathrm{NBr}$, dioxane: water (9:1), reflux, $12 \mathrm{~h}$.

Scheme 3.

Synthesis of indoles and GAT 211 aza-analogs for site III and site IV variation 


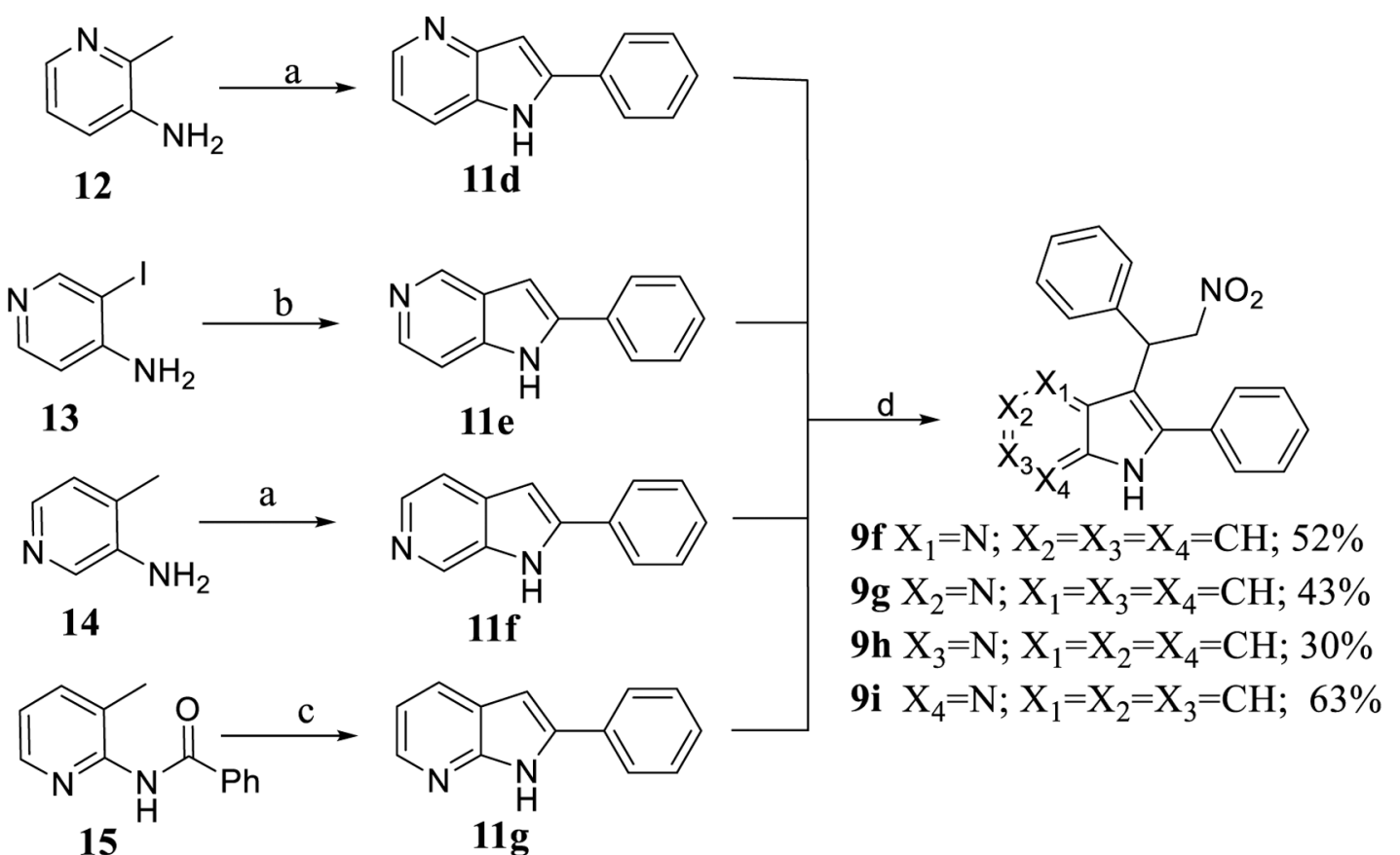

Reagents and Conditions: a) ethyl benzoate, sec-BuLi, THF, $78{ }^{0} \mathrm{C}, 1 \mathrm{hr}, 40-53 \%$; b) i) phenylacetylene, CuI, $\mathrm{Pd}\left(\mathrm{PPh}_{3}\right)_{4}$, DIPEA, DMF, 93\%; ii) $\mathrm{KO}{ }^{\mathrm{t}} \mathrm{Bu}, 1$-methylpyrrolidine -2one, $100{ }^{\circ} \mathrm{C}, 91 \%$; c) sec-BuLi, THF, $78{ }^{0} \mathrm{C}, 1 \mathrm{hr}, 52 \%$; d) $\beta$-nitrostyrene, ${ }^{\mathrm{n}} \mathrm{BuLi}$, THF, $-78{ }^{0} \mathrm{C}$

Scheme 4.

Synthesis of aza analogs of GAT211 for Site I variations 
<smiles></smiles><smiles>O=[N+]([O-])/C=C/c1ccccc1</smiles>
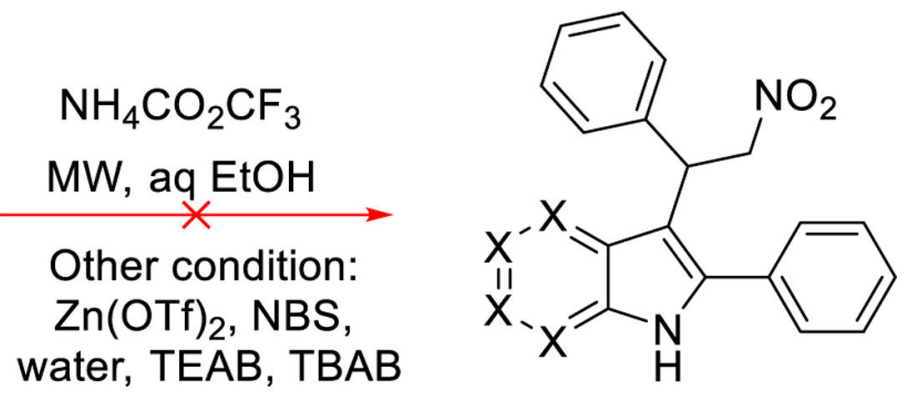

${ }^{n}$ BuLi, THF

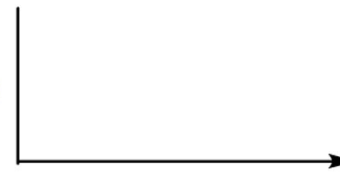<smiles></smiles>

Scheme 5:

Alternative strategy employed for Michael addition reaction with electron-deficient azaindoles. 


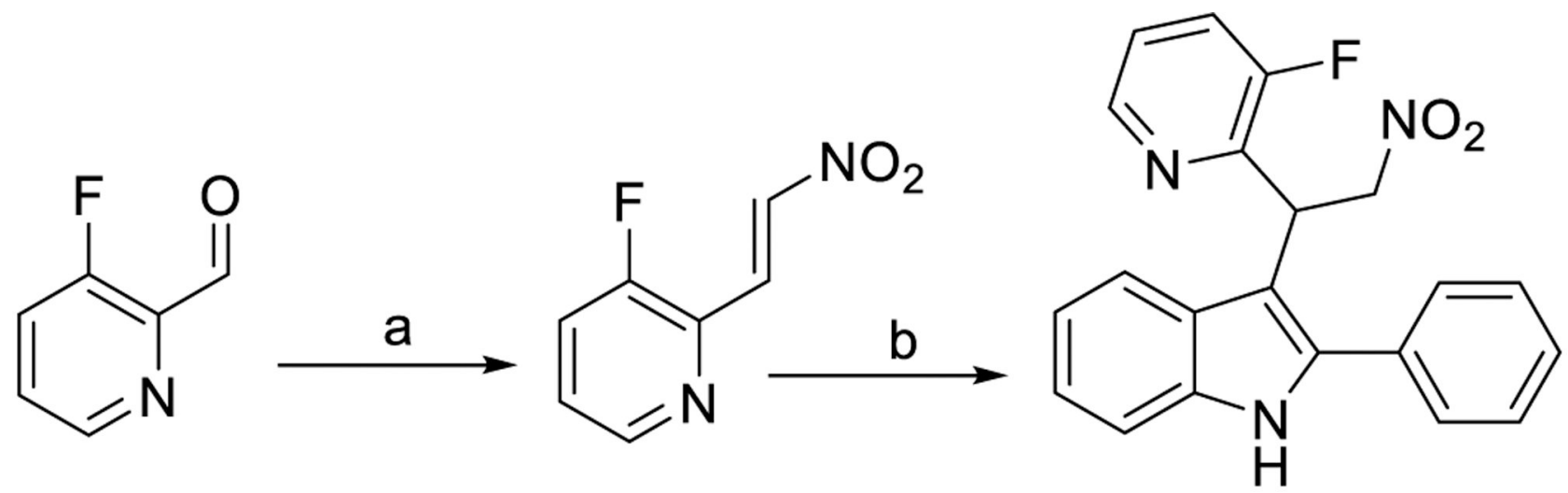

7d

8d

9j

Reagents and Conditions: a) i) KOt-Bu, $\mathrm{CH}_{3} \mathrm{NO}_{2}$, t-BuOH:THF, $0{ }^{0} \mathrm{C}, 2 \mathrm{hrs}, 85 \%$; ii) $\mathrm{AC}_{2} \mathrm{O}, 4$-DMAP, DCM, rt, $3 \mathrm{hrs}, 72 \%$; b) 5, $\mathrm{NH}_{4} \mathrm{CO}_{2} \mathrm{CF}_{3}, 10 \%$ aq EtOH, reflux, $12 \mathrm{hrs}, 90 \%$.

Scheme 6.

Synthesis of fluoro and aza hybrid analog $\mathbf{9 j}$. 
Table 1.

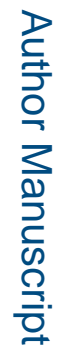

PAM activity of fluoro-analogs of GAT211

\begin{tabular}{|c|c|c|c|c|c|c|}
\hline \multirow{2}{*}{ Compound } & \multirow{2}{*}{ Structure } & \multicolumn{2}{|l|}{ cAMP } & \multicolumn{2}{|c|}{ $\beta$ arrestin2 } & \multirow{2}{*}{$\operatorname{cLog} P$} \\
\hline & & $\mathrm{EC}_{50}(\mathrm{nM})$ & $E_{\text {Max }}(\%)$ & $\mathrm{EC}_{50}(\mathrm{nM})$ & $E_{\text {Max }}(\%)$ & \\
\hline 6d (GAT211) & & $230(140-370)$ & $110 \pm 6.8$ & $940(540-1,800)^{\wedge}$ & $46 \pm 9.5^{\mathcal{S}}$ & 5.03 \\
\hline $6 e$ & & $130(58-280)$ & $120 \pm 9.0$ & $900(730-1,100)^{\wedge}$ & $37 \pm 1.3^{\mathcal{\xi}}$ & 5.16 \\
\hline 6f & & $191(96-380)$ & $130 \pm 8.5$ & $740(540-990)^{\wedge}$ & $23 \pm 1.2^{\mathcal{S}}$ & 5.16 \\
\hline $6 \mathrm{~g}$ & & $110(59-190)$ & $120 \pm 6.0$ & $1,100(880-1,300)^{\wedge}$ & $38 \pm 1.3^{\mathcal{S}}$ & 5.16 \\
\hline $6 h$ & & $22(8.4-58)^{*}$ & $120 \pm 6.1$ & $750(630-880)^{\wedge}$ & $45 \pm 1.3^{\mathcal{S}}$ & 5.16 \\
\hline $6 \mathbf{i}$ & & $1400(1,100-1,700)^{*}$ & $140 \pm 6.2$ & $710(417-1,210)$ & $7.0 \pm 0.54^{\dagger+t, \xi}$ & 5.16 \\
\hline
\end{tabular}

J Med Chem. Author manuscript; available in PMC 2020 July 23. 


\begin{tabular}{|c|c|c|c|c|c|c|}
\hline \multirow{2}{*}{ Compound } & \multirow{2}{*}{ Structure } & \multicolumn{2}{|l|}{ cAMP } & \multicolumn{2}{|c|}{ Barrestin2 } & \multirow{2}{*}{ cLogP } \\
\hline & & $\mathrm{EC}_{50}(\mathrm{nM})$ & $E_{\text {Max }}(\%)$ & $\mathrm{EC}_{50}(\mathrm{nM})$ & $E_{\operatorname{Max}}(\%)$ & \\
\hline $\mathbf{6 j}$ & & $80(29-220)$ & $140 \pm 13^{\dagger}$ & $1,300(1,100-1,600)^{\wedge}$ & $55 \pm 2.0^{\xi}$ & 5.16 \\
\hline $6 \mathbf{k}$ & & $1,600(1,200-2,300) *$ & $120 \pm 6.2$ & $>10,000$ & $-2.2 \pm 6.7^{\dagger \dagger} \delta$ & 5.16 \\
\hline $6 a$ & & $43(28-66)^{*}$ & $110 \pm 3.6$ & $1,060(840-1,300)^{\wedge}$ & $63 \pm 2.3^{\mathcal{\xi}}$ & 5.16 \\
\hline $6 \mathrm{~b}$ & & $730(280-1,900)$ & $130 \pm 18$ & $2,500(1,200-5,400)$ & $19 \pm 3.3^{\dagger, \mathcal{S}}$ & 5.16 \\
\hline $6 c$ & & $440(280-700)$ & $110 \pm 6.6$ & $>10,000$ & $8.0 \pm 2.7^{\dagger \dagger \dagger \mathcal{S}}$ & 5.16 \\
\hline 61 & & $58(34-97)^{*}$ & $110 \pm 5.0$ & $1,140(870-1,500)^{\wedge}$ & $54 \pm 2.8^{\mathcal{S}}$ & 5.3 \\
\hline $6 \mathrm{~m}$ & & $21(14-30)^{*}$ & $100 \pm 3.2$ & $680(580-790)^{\wedge}$ & $76 \pm 1.8^{\dagger+t}$ & 5.3 \\
\hline
\end{tabular}

J Med Chem. Author manuscript; available in PMC 2020 July 23. 


\begin{tabular}{|c|c|c|c|c|c|c|}
\hline \multirow{2}{*}{ Compound } & \multirow{2}{*}{ Structure } & \multicolumn{2}{|c|}{ cAMP } & \multicolumn{2}{|c|}{ Barrestin2 } & \multirow{2}{*}{$\operatorname{cLog} P$} \\
\hline & & $\mathrm{EC}_{50}(\mathrm{nM})$ & $E_{\text {Max }}(\%)$ & $\mathrm{EC}_{50}(\mathrm{nM})$ & $E_{\text {Max }}(\%)$ & \\
\hline $6 r$ & & $28(16-49)^{*}$ & $93 \pm 4.2$ & $750(570-980)^{\wedge}$ & $71 \pm 3.3$ & 5.43 \\
\hline $6 s$ & & $9.1(3.4-24)^{*}$ & $93 \pm 4.9$ & $510(340-760)^{\wedge}$ & $82 \pm 4.8^{\dagger \dagger}$ & 5.43 \\
\hline $6 n$ & & $1,300(330-6,000)$ & $47 \pm 5.6^{t+t}$ & $1,100(890-1,300)$ & $32 \pm 0.99$ & 5.3 \\
\hline 60 & & $270(190-380)$ & $121 \pm 5.4$ & $700(440-1,100)^{\wedge}$ & $27 \pm 1.9^{\mathcal{\xi}}$ & 5.3 \\
\hline $6 p$ & & $1,150(430-3,100)^{*}$ & $91 \pm 12$ & $2,100(1,800-2,600)$ & $56 \pm 2.0^{\mathcal{\xi}}$ & 5.43 \\
\hline $6 q$ & & $230(160-340)$ & $110 \pm 5.3$ & $1,100(910-1,400)^{\wedge}$ & $43 \pm 1.6^{\mathcal{S}}$ & 5.43 \\
\hline
\end{tabular}

CB1 PAM activity was quantified for cAMP inhibition using the DiscoveRx HitHunter assay (CHO hCB1R) in cells treated with CP55,940 at $\mathrm{EC} 20+$ GAT211 analog for $30 \mathrm{~min}$, and for $\beta$ arrestin2 recruitment using the DiscoveRx PathHunter assay (CHO hCB1R) in cells treated with CP55,940 at EC20 + GAT211 analog for 90 min. Data were fit to a variable slope (4 parameter) non-linear regression in GraphPad (v. 7). Data are 
mean with 95\% confidence interval (CI) (EC50) or mean \pm SEM, $n=1-3$ independent experiments performed in duplicate. Statistical analyses were by non-overlapping CI or two-way ANOVA followed by Bonferroni's post-hoc test.

* $P<0.05$ relative to GAT211 within assay;

$\hat{P}<0.05$ relative to cAMP assay within compound;

${ }^{\dagger} P<0.05$,

${ }^{\# t} P<0.01$,

${ }^{t}{ }^{t} P<0.001$ relative to GAT211 within assay;

$\S_{P<0.001 \text { relative to cAMP assay within compound. }}$ 
Table 2.

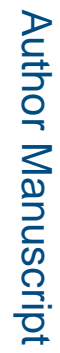

PAM activity of aza-analogs of GAT211

\begin{tabular}{|c|c|c|c|c|c|c|c|c|}
\hline \multirow{2}{*}{ Compound } & \multirow{2}{*}{ Structure } & \multicolumn{2}{|c|}{ cAMP } & \multicolumn{2}{|c|}{ ßarrestin2 } & \multirow{2}{*}{ cLogP } & \multicolumn{2}{|c|}{$\begin{array}{l}\text { Thermodynamic } \\
\text { Aqueous solubility }\end{array}$} \\
\hline & & $\mathrm{EC}_{50}(\mathrm{nM})$ & $E_{\text {Max }}(\%)$ & $\mathbf{E C}_{50}(\mathrm{nM})$ & $E_{\text {Max }}(\%)$ & & $\mu \mathbf{M}$ & $\mu \mathrm{g} / \mathrm{mL}$ \\
\hline 6d & & $230(140-370)$ & $114 \pm 6.8$ & $\begin{array}{c}940(540- \\
1,800)^{\wedge}\end{array}$ & $46 \pm 9.5^{\mathcal{S}}$ & 5.03 & 7.8 & 2.7 \\
\hline $9 f$ & & $>10,000$ & $81 \pm 4.4$ & $\begin{array}{c}1,600 \\
(1,300- \\
2,000)\end{array}$ & $30 \pm 1.1^{\xi}$ & 4.16 & 11.2 & 3.8 \\
\hline $9 \mathrm{~g}$ & & $>10,000$ & $4.0 \pm 2.5^{t+t}$ & $>10,000$ & $2.8 \pm 2.4$ & 3.91 & 23.6 & 8.1 \\
\hline 9h & & $\begin{array}{c}450(47- \\
4,200)\end{array}$ & $5.2 \pm 3.5^{t+t t}$ & $>10,000$ & $5.1 \pm 0.35$ & 3.91 & 6.8 & 2.3 \\
\hline $9 \mathbf{i}$ & & $\begin{array}{c}1,100(1,100- \\
1,700)^{*}\end{array}$ & $39 \pm 12^{\dagger}$ & $>10,000$ & $7.0 \pm 0.89$ & 4.16 & 159.0 & 54.6 \\
\hline 9d & & $\begin{array}{c}1,100(630- \\
1,700)^{*}\end{array}$ & $150 \pm 12$ & $>10,000$ & $9.2 \pm 8.7^{\mathcal{S}}$ & 3.91 & 4.9 & 1.7 \\
\hline
\end{tabular}

J Med Chem. Author manuscript; available in PMC 2020 July 23. 


\begin{tabular}{|c|c|c|c|c|c|c|c|c|}
\hline \multirow{2}{*}{ Compound } & \multirow{2}{*}{ Structure } & \multicolumn{2}{|c|}{ cAMP } & \multicolumn{2}{|c|}{ $\beta$ arrestin2 } & \multirow{2}{*}{$\operatorname{cLog} P$} & \multicolumn{2}{|c|}{$\begin{array}{l}\text { Thermodynamic } \\
\text { Aqueous solubility }\end{array}$} \\
\hline & & $\mathrm{EC}_{50}(\mathrm{nM})$ & $E_{\text {Max }}(\%)$ & $\mathrm{EC}_{50}(\mathrm{nM})$ & $E_{\operatorname{Max}}(\%)$ & & $\mu \mathrm{M}$ & $\mu \mathrm{g} / \mathrm{mL}$ \\
\hline $9 \mathrm{e}$ & & $\begin{array}{c}3,100(1,400- \\
6,700)^{*}\end{array}$ & $88 \pm 18$ & $\begin{array}{c}1,600(980- \\
2,700)\end{array}$ & $19 \pm 1.7^{\mathcal{\xi}}$ & 3.91 & 2.1 & 0.7 \\
\hline $9 a$ & & $260(140-480)$ & $130 \pm 7.8$ & $>10,000$ & $5.8 \pm 3.8^{\mathcal{S}}$ & 4.15 & 2.8 & 1.0 \\
\hline $9 b$ & & $\begin{array}{l}3,100(634- \\
15,000)^{*}\end{array}$ & $170 \pm 39$ & $>10,000$ & $-8.1 \pm 7.9^{\mathcal{S}}$ & 3.91 & 1.1 & 0.4 \\
\hline $9 \mathrm{c}$ & & $510(330-780)$ & $110 \pm 6.4$ & $\begin{array}{c}4,000 \\
(2,200- \\
7,500)^{\wedge}\end{array}$ & $25 \pm 4.4^{\xi}$ & 3.91 & 36.7 & 12.6 \\
\hline 9j & & $\begin{array}{l}1,900(630- \\
3,700)^{*}\end{array}$ & $95 \pm 16$ & $>10,000$ & $-1.4 \pm 2.7^{\mathcal{S}}$ & 4.28 & -- & -- \\
\hline
\end{tabular}

PAM activity was quantified for cAMP inhibition using the DiscoveRx HitHunter assay (CHO hCB1R) in cells treated with CP55,940 at EC20 + GAT211 analog for $30 \mathrm{~min}$, and for ßarrestin2 recruitment using the DiscoveRx PathHunter assay (CHO hCB1R) in cells treated with CP55,940 at EC20 + GAT211 analog for 90 min. Data were fit to a variable slope (4 parameter) non-linear regression in GraphPad (v. 7). Data are mean with 95\% confidence interval (CI) (EC50) or mean \pm SEM, $n=1-3$ independent experiments performed in duplicate. Statistical analyses were by nonoverlapping CI or two-way ANOVA followed by Bonferroni's post-hoc test.

${ }_{P}^{*}<0.05$ relative to GAT211 within assay;

${ }_{P} P<0.05$ relative to cAMP assay within compound;

${ }^{\dagger} P<0.05$,

${ }^{\dagger \dagger} P<0.01$,

${ }^{\dagger \dagger} P<0.001$ relative to GAT211 within assay; 
$\xi_{P<0.001 \text { relative to cAMP assay within compound. }}$ 
Table 3.

Metabolic stability and kinetic aqueous solubility of GAT211(6d), 6r, 9j and 6s.

\begin{tabular}{|c|c|c|c|c|c|}
\hline \multirow{2}{*}{ Compound } & \multicolumn{2}{|c|}{ Human } & \multicolumn{2}{c|}{ Rat } & \multirow{2}{*}{$\begin{array}{c}\text { Kinetic aqueous solubility } \\
(\boldsymbol{\mu M})\end{array}$} \\
\cline { 2 - 5 } & $\begin{array}{c}\text { microsomal Clint } \\
(\mu \mathbf{L} / \mathbf{m i n} / \mathbf{m g} \text { protein) }\end{array}$ & $\mathbf{t}_{\mathbf{1 / 2}}(\mathbf{m i n})$ & $\begin{array}{c}\text { microsomal Clint } \\
(\mu \mathrm{L} / \mathbf{m i n} / \mathbf{m g} \text { protein) }\end{array}$ & $\mathbf{t}_{\mathbf{1} / \mathbf{2}}(\mathbf{m i n})$ & 1.56 \\
\hline GAT211 (6d) & 81.2 & 28.4 & 368 & 6.27 & 1.56 \\
\hline $\mathbf{6 r}$ & 44.9 & 51.5 & 248 & 9.31 & 3.13 \\
\hline $\mathbf{9 j}$ & 84.5 & 27.4 & 556 & 4.08 & 1.56 \\
\hline $\mathbf{6 s}$ & 44.4 & 52.1 & 94.0 & 24.6 & \\
\hline
\end{tabular}


Table 4.

Agonist activity and PAM-dependent shift in CP55,940 potency and efficacy for lead GAT211 derivative compounds.

\begin{tabular}{|c|c|c|}
\hline Compound Agonist Activity & $\mathbf{E C}_{\mathbf{5 0}}(\mathbf{n M})$ & $\boldsymbol{E}_{\text {Min }}(\boldsymbol{\%}$ Forskolin) \\
\hline CP55,940 & $18 \pm 0.11$ & $29 \pm 3.5$ \\
\hline GAT211 (6d) & $240 \pm 0.17$ & $39 \pm 7.5$ \\
\hline $\mathbf{6 r}$ & $27 \pm 0.11$ & $32 \pm 3.5$ \\
\hline $\mathbf{9 j}$ & $690 \pm 2.6$ & $55 \pm 8.4$ \\
\hline $\mathbf{6 s}$ & $26 \pm 0.13$ & $30 \pm 3.9$ \\
\hline
\end{tabular}

\begin{tabular}{|c|c|c|c|c|c|c|}
\hline \multicolumn{7}{|c|}{ Positive Allosteric Modulator Activity } \\
\hline \multicolumn{7}{|c|}{ CP55,940 EC $_{50}(\mathrm{nM})$ at $\log [$ Compound $] M$} \\
\hline Compound & Vehicle (0) & -8 & -7.5 & -7 & -6.5 & $\Delta \mathrm{EC}_{\mathbf{5 0}}(\mathbf{n M})$ \\
\hline GAT211 (6d) & \multirow{4}{*}{$22 \pm 6.0$} & $17 \pm 0.92$ & $17 \pm 2.6$ & $17 \pm 5$ & $17 \pm 1.7$ & $-5.1 \pm 4.6$ \\
\hline 6r & & $20 \pm 2.6$ & $27 \pm 11$ & $19 \pm 11$ & $10 \pm 7.5$ & $-12 \pm 5.7$ \\
\hline 9j & & $22 \pm 10$ & $20 \pm 5.9$ & $18 \pm 1.9$ & $17 \pm 3$ & $-4.9 \pm 3.8$ \\
\hline 6s & & $14 \pm 3.8$ & $12 \pm 3.5$ & $10 \pm 3.9$ & $9.0 \pm 2.0$ & $-12 \pm 8.0$ \\
\hline \multicolumn{7}{|c|}{ CP55,940 $E_{\text {Max }}(\%$ Forskolin $)$ at $\log [$ Compound $] M$} \\
\hline Compound & Vehicle (0) & -8 & -7.5 & -7 & -6.5 & $\Delta E_{M a x}(\%$ Forskolin $)$ \\
\hline 6d & \multirow{4}{*}{$100 \pm 6.4$} & $101 \pm 7.4$ & $100 \pm 11$ & $82 \pm 6.7$ & $75 \pm 11$ & $25 \pm 3.0$ \\
\hline 6r & & $76 \pm 6.4$ & $58 \pm 9.2$ & $46 \pm 6.6$ & $32 \pm 4.7$ & $68 \pm 4.3$ \\
\hline $9 \mathbf{j}$ & & $101 \pm 9.0$ & $108 \pm 13$ & $103 \pm 12$ & $83 \pm 9.3$ & $17 \pm 10$ \\
\hline $6 s$ & & $74 \pm 5.7$ & $63 \pm 3.7$ & $52 \pm 1.5$ & $33 \pm 13$ & $67 \pm 15$ \\
\hline
\end{tabular}

Compound activity was quantified for cAMP inhibition in cells treated with $10-300 \mathrm{nM}$ GAT compound + CP55,940. Data were fit to a variable slope (4 parameter) non-linear regression in GraphPad (v. 7). n $\geq 3$ independent experiments performed in triplicate from Figures 2 and 3. EMin from figure 2 refers to the lower plateau (i.e. bottom) of the concentration-response curves observed with high concentrations of compound. EMax from Figure 3 refers to the upper plateau (i.e. top) of the concentration-response curves observed at low concentrations of orthosteric agonist CP55,940. Data are expressed as the difference between the agonist (CP55,940) alone and the maximal concentration of GAT compound used, mean \pm SEM. 
Table 5.

Agonist and PAM activity of lead GAT211 derivative compounds.

\begin{tabular}{|c|c|c|c|c|}
\hline \multirow[b]{3}{*}{ Compound } & \multicolumn{4}{|c|}{ сAMP } \\
\hline & \multicolumn{2}{|c|}{ Vehicle } & \multicolumn{2}{|c|}{ + 100 nM CP55,940 } \\
\hline & $\mathrm{EC}_{50}(\mathrm{nM})$ & $E_{\text {Min }}(\%$ Compound Max $)$ & $\mathrm{EC}_{50}(\mathrm{nM})$ & $E_{M \text { in }}(\%$ Compound Max $)$ \\
\hline GAT211 (6d) & $78(22-270)$ & $1.8 \pm 8.5$ & $8.1(6.1-17)$ & $21 \pm 5.3$ \\
\hline $6 \mathbf{r}$ & $4.3(1.4-13)$ & $4.2 \pm 0.69$ & $2.2(0.48-9.7)$ & $9.0 \pm 0.72$ \\
\hline $9 \mathbf{j}$ & $>10,000$ & $6.9 \pm 2.8$ & $14(8.4-26)$ & $11 \pm 3.7$ \\
\hline \multirow[t]{3}{*}{$6 s$} & $3.9(1.8-8.7)$ & $18 \pm 4.1$ & $1.7(0.46-6.4)$ & $10 \pm 1.7$ \\
\hline & \multicolumn{4}{|c|}{ ßarrestin2 } \\
\hline & \multicolumn{2}{|c|}{ Vehicle } & \multicolumn{2}{|c|}{ + 100 nM CP55,940 } \\
\hline Compound & $\mathbf{E C}_{50}(\mathrm{nM})$ & $E_{\text {Max }}(\%$ CP55,940) & $\mathbf{E C}_{50}(\mathbf{n M})$ & $E_{\text {Max }}(\%$ CP55,940) \\
\hline GAT211 (6d) & $1,200(510-2,700)$ & $27 \pm 3.2$ & $200(130-310)$ & $72 \pm 1.7$ \\
\hline $6 \mathbf{r}$ & $1,600(750-6,500)$ & $34 \pm 6.4$ & $190(120-320)$ & $130 \pm 4.6$ \\
\hline $9 \mathbf{j}$ & $3,300(800-6,200)$ & $23 \pm 10$ & $>10,000$ & $24 \pm 1.7$ \\
\hline $6 s$ & $>10,000$ & $25 \pm 7.6$ & $3,500(1,600-7,600)$ & $130 \pm 12$ \\
\hline
\end{tabular}

Compound activity was quantified for cAMP inhibition using the DiscoveRx HitHunter assay (CHO hCB1R) in cells treated with GAT compound alone or $100 \mathrm{nM} \mathrm{CP55,940} \mathrm{+} \mathrm{GAT} \mathrm{compound} \mathrm{for} 90 \mathrm{~min}$, and for $\beta$ arrestin2 recruitment using the DiscoveRx PathHunter assay (CHO hCB1R) in cells treated with GAT compound alone or $100 \mathrm{nM} 100 \mathrm{nM}$ CP55,940 + GAT compound for $90 \mathrm{~min}$. Data were normalized to \% Forskolin response within each compound treatment for cAMP \pm S.E.M.; or $\%$ CP55,940 relative to baseline \pm S.E.M. and fit to a variable slope (4 parameter) nonlinear regression in GraphPad (v. 7). $n \geq 6$ independent experiments performed in triplicate. EC50 (nM) data are mean with $95 \%$ confidence interval

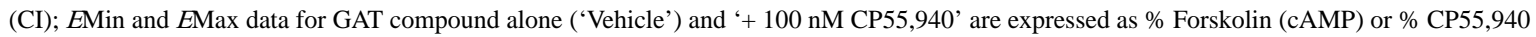
$($ arrestin2) \pm SEM. Data are from figure 5 . 